IZA DP No. 6790

The Elite Illusion: Achievement Effects at Boston and New York Exam Schools

Atila Abdulkadiroğlu Joshua D. Angrist Parag A. Pathak

August 2012 


\title{
The Elite Illusion: Achievement Effects at Boston and New York Exam Schools
}

\author{
Atila Abdulkadiroğlu \\ Duke University \\ Joshua D. Angrist \\ MIT, NBER and IZA \\ Parag A. Pathak \\ MIT and NBER \\ Discussion Paper No. 6790 \\ August 2012 \\ IZA \\ P.O. Box 7240 \\ 53072 Bonn \\ Germany \\ Phone: +49-228-3894-0 \\ Fax: +49-228-3894-180 \\ E-mail: iza@iza.org
}

Any opinions expressed here are those of the author(s) and not those of IZA. Research published in this series may include views on policy, but the institute itself takes no institutional policy positions.

The Institute for the Study of Labor (IZA) in Bonn is a local and virtual international research center and a place of communication between science, politics and business. IZA is an independent nonprofit organization supported by Deutsche Post Foundation. The center is associated with the University of Bonn and offers a stimulating research environment through its international network, workshops and conferences, data service, project support, research visits and doctoral program. IZA engages in (i) original and internationally competitive research in all fields of labor economics, (ii) development of policy concepts, and (iii) dissemination of research results and concepts to the interested public.

IZA Discussion Papers often represent preliminary work and are circulated to encourage discussion. Citation of such a paper should account for its provisional character. A revised version may be available directly from the author. 


\section{ABSTRACT}

\section{The Elite Illusion: Achievement Effects at Boston and New York Exam Schools ${ }^{*}$}

Parents gauge school quality in part by the level of student achievement and a school's racial mix. The importance of school characteristics in the housing market can be seen in the jump in house prices at school district boundaries where peer characteristics change. The question of whether schools with more attractive peers are really better in a value-added sense remains open, however. This paper uses a fuzzy regression-discontinuity design to evaluate the causal effects of peer characteristics. Our design exploits admissions cutoffs for Boston and New York City's heavily over-subscribed exam schools. Successful applicants near admissions cutoffs for the least selective of these schools move from schools with scores near the bottom of the state SAT score distribution to a school with scores near the median. Successful applicants near admissions cutoffs for the most selective of these schools move from above-average schools to schools with students drawn from the extreme upper tail. Exam school students can also expect to study with fewer nonwhite classmates than unsuccessful applicants. Our estimates suggest that the marked changes in peer characteristics at exam school admissions cutoffs have little causal effect on test scores or college quality.

JEL Classification: $\quad 121,128$, C21

Keywords: human capital, peer effects, school quality

Corresponding author:

Joshua D. Angrist

MIT Economics E52-391

77 Massachusetts Ave.

Cambridge, MA, 02142

USA

E-mail: angrist@mit.edu

\footnotetext{
* Our thanks to Kamal Chavda, Jack Yessayan, and the Boston Public Schools; and to Jennifer BellEllwanger, Thomas Gold, Jesse Margolis, and the New York City Department of Education, for graciously sharing their data. The views expressed here are those of the authors and do not reflect the views of either the Boston Public Schools or the NYC Department of Education. We're grateful for comments from participants in the June 2010 Tel-Aviv Frontiers in the Economics of Education conference, the Summer 2011 NBER Labor Studies workshop, and the December 2011 HongKong Human Capital Symposium. Thanks also go to Jonah Rockoff for comments and data on teacher tenure in NYC. We're also grateful to Daron Acemoglu, Gary Chamberlain, Yingying Dong, Glenn Ellison, and Guido Imbens for many helpful discussions. Weiwei Hu and Miikka Rokkanen provided superb research assistance. Pathak thanks the Graduate School of Business at Stanford University, where parts of this work were completed, and the NSF for financial support.
} 


\section{Introduction}

A three bedroom house on the northern edge of Newton, Massachusetts costs $\$ 412,000$ (in 2008 dollars), while across the street, in Waltham, a similar place can be had for $\$ 316,000 .{ }^{1}$ Black (1999) attributes this and many similar Massachusetts contrasts to differences in perceived school quality. Indeed, 92 percent of Newton's high school students are graded proficient in math, while only 78 percent are proficient in Waltham. These well-controlled comparisons suggest something changes at school district boundaries. Parents looking for a home are surely aware of achievement differences between Newton and Waltham, and many are willing to pay a premium to see their children attend what appear to be better schools. At the same time, it's clear that differences in achievement levels can be a highly misleading guide to value-added, a possibility suggested by theoretical and empirical analyses in Rothstein (2006), Hastings, Kane, and Staiger (2009), and MacLeod and Urquiola (2009), among others.

Similar observations can be made regarding racial composition and home prices. For over a halfcentury, American education policy has struggled with the challenge of racial integration. The view that racial mixing contributes to learning motivates a range of social interventions ranging from busing and court supervision of school assignment, to Boston's iconic Metco program, which sends minority children to mostly white suburban districts. In this context as well, home-buying parents vote with their housing dollars - typically for more white classmates - as shown recently by Boustan (2012) using cross-border comparisons in the spirit of Black (1999). ${ }^{2}$

An ideal experiment designed to reveal causal effects of peer characteristics would randomly assign the opportunity to attend schools with high-achieving peers and fewer minority classmates. The subjects of such a study should be a set of families likely to take advantage of such an opportunity. Imagine sampling parents in real estate offices choosing between homes in Newton and Waltham. We might randomly offer a subset of those who settle for Waltham a voucher that entitles them to send their children to Newton schools in spite of their Waltham address. This manipulation bears some resemblance to the Moving to Opportunity (MTO) experiment, which randomly allocated housing vouchers valid only in low-poverty neighborhoods. MTO was a complicated intervention, however, that did not seek to manipulate the school environment in particular. In fact, peer achievement changed surprisingly little for most school children in the MTO treatment group (see Kling, Liebman, and Katz (2007) and Sanbonmatsu, Ludwig, Katz, Gennetian, Duncan, Kessler, McDade, and Lindau (2011)).

While a perfect peer characteristics experiment seems hard to engineer, an important set of existing institutions induces quasi-experimental variation that comes close to the ideal experiment. A network of selective public schools in Boston and New York known as exam schools offer public school students the opportunity to attend schools with much higher achieving peers. Moreover, in these mostly

\footnotetext{
${ }^{1}$ These are average prices of 42 three bedroom units in Newton and 27 units in Waltham, separated by 0.1 miles or less, as quoted on Greater Boston's Multiple Listing Service for transactions between 1998-2008.

${ }^{2}$ Guryan (2004) finds that court-order integration schemes increase nonwhite high school graduation rates without hurting whites, but evidence on the achievement consequences of busing for racial balance is mixed (Hoxby (2000) is a seminal study; see also references in Angrist and Lang (2004)).
} 
nonwhite districts, exam schools have a markedly higher proportion of white classmates than do the public schools that applicants are otherwise likely to attend. Of course, exam school admissions are not made by random assignment; rather, students are selected by an admissions test with sharp cutoffs for each school and cohort. This paper exploits these admissions cutoffs in a fuzzy regression continuity design (RD) that identifies causal effects of peer achievement and racial composition for applicants to the six traditional exam schools operating in Boston and New York. Application of RD in this context generates a number of methodological challenges related to the real-world messiness of school assignment and the exclusion restrictions used to interpret 2SLS estimates. Solutions for these problems are detailed in the sections that follow.

\section{Institutional Background}

Boston's three exam schools span grades 7-12. The best-known is the Boston Latin School, which enrolls about 2,400 students. Seen by many as the crown jewel of Boston's public school system, Boston Latin School was named a top 20 U.S. high school in the inaugural 2007 U.S. News \& World Report school rankings. Founded in 1635, the Boston Latin School is America's first public school and the oldest still open (Goldin and Katz, 2008). ${ }^{3}$ Boston Latin School is a model for other exam schools, including the Brooklyn Latin School, recently opened in New York (Jan, 2006). The second oldest Boston exam school is Boston Latin Academy, formerly the Girls' Latin School. Opened in 1877, Latin Academy first admitted boys in 1972 and currently enrolls about 1,700 students. The John D. O'Bryant High School of Mathematics and Science (formerly Boston Technical High) is Boston's third exam school; O'Bryant opened in 1893 and now enrolls about 1,200 students.

New York's three original academic exam schools are Stuyvesant High School, Bronx High School of Science, and Brooklyn Technical High School, each spanning grades 9-12. The New York exam schools were established in the first half of the $20^{\text {th }}$ century and share a number of features with Boston's exam schools. Stuyvesant and Bronx Science appear on Newsweek's list of elite public high schools and all three have been in the U.S. News \& World Report rankings. Stuyvesant enrolls just over 3,000 students, Bronx Science enrolls 2,600-2,800 students, and Brooklyn Tech has about 4,500 students. New York opened three new exam schools in 2002: the High School for Math, Science and Engineering at City College, the High School of American Studies at Lehman College, and Queens High School for the Sciences at York College. In 2005, Staten Island Technical High School converted to exam status, while the Brooklyn Latin School opened in 2006. The admissions process for these new schools is the same as for the three original exam schools, but we omit the new schools because they are not as well established as New York's traditional exam schools, and some have unusual characteristics such as small enrollment. Finally, we've structured the New York analysis to parallel that for Boston. ${ }^{4}$

\footnotetext{
${ }^{3}$ Boston Latin School was established one year before Harvard College. Local lore has it that Harvard was founded to give graduates of Latin a place to continue their studies.

${ }^{4}$ Estimates including New York's new exam schools are similar to those generated by the three-school sample. Other selective New York public schools include the Fiorello H. LaGuardia High School, which focuses on visual and performing arts and admits students by audition, and Hunter College High School, which uses a unique admissions procedure and is not operated by the New York Department of Education.
} 
Boston Public Schools span a range of peer achievement unique among American urban districts. Like many urban students elsewhere in the U.S., Boston exam school applicants who fail to enroll in an exam school end up at schools with average SAT scores well below the state average, in this case, at schools close to the 5th percentile of the distribution of school averages in the state. By contrast, O'Bryant's average SAT falls at the 40th percentile of the state distribution of averages, a big step up from the overall BPS average, but not elite in an absolute sense. Successful Boston Latin Academy applicants find themselves at a school with average SATs around the 80th percentile of the distribution of school means, while the average SAT at the Boston Latin School is the fourth highest among public schools in the state.

Data from New York's exam schools enrich this picture by allowing us to evaluate the impact of peer exposure in the extreme upper tail. The least selective of New York's three traditional exam schools, Brooklyn Tech, is attended by students with average SATs at around the 99th percentile of the distribution of average SATs in New York state, a level comparable to the Boston Latin School. Successful applicants to Brooklyn Tech typically move from schools where peer achievement is around the 30th percentile of the school average SAT distribution. Students at the two most selective New York exam schools are exposed to the brightest of classmates, with the Bronx Science average at percentile 99.9, while Stuyvesant has the highest average SAT scores in New York state, placing it among the top 5 public schools nationwide.

As far as we know, ours is one of two RD analyses of achievement effects at highly selective U.S. exam schools. In independent contemporaneous work, Dobbie and Fryer (2011) estimate the reduced-form impact of admissions offers at New York exam schools; their analysis shows no impact on college enrollment or quality. Selective high schools have also been studied elsewhere. Pop-Eleches and Urquiola (2010) estimate the effects of attending selective high schools in Romania, where the admissions process is similar to that used by Boston's exam schools. Selective Romanian high schools appear to boost scores on the high-stakes Romanian Baccalaureate test. Jackson (2010) similarly reports large score gains for those attending a selective school in Trinidad and Tobago. On the other hand, Clarke (2008) finds only modest score gains at selective UK schools. Likewise, using admissions lotteries to analyze the consequences of selective middle school attendance in China, Zhang (2010) finds no achievement gains for students randomly offered seats at a selective school. In contrast with our work, none of these studies interpret the reduced-form impact of exam school offers as operating through specific causal channels for which there is a clear first stage. ${ }^{5}$

Selective institutions are more commonly found in American higher education than at the secondary level. Dale and Krueger (2002) compare students who were accepted by the same sets of colleges but made different choices in terms of selectivity. Perhaps surprisingly, this comparison shows no earnings advantage for those who went to more selective schools, with the possible exceptions of minority and first-generation college applicants in more recent data (Dale and Krueger, 2011). In contrast with the Dale and Krueger results, Hoekstra (2009) reports that graduates of a state university's

\footnotetext{
${ }^{5}$ Pop-Eleches and Urquiola (2010) report a peer achievement first-stage in their analysis of Romanian selective schools, but the effect of a Romanian exam school offer on peer composition is small and, as the authors note, unlikely to explain any exam school reduced form.
} 
relatively selective flagship campus earn more later on than those who went elsewhere.

Finally, a large literature looks at peer effects in educational settings. Examples include Hoxby (2000), Hanushek, Kain, Markman, and Rivkin (2003), Angrist and Lang (2004), Hoxby and Weingarth (2006), Lavy, Silva, and Weinhardt (2009), Ammermueller and Pischke (2009), Imberman, Kugler, and Sacerdote (2012), and Carrell, Sacerdote, and West (2012). Findings in the voluminous education peer effects literature are mixed and not easily summarized. It seems fair to say, however, that the likelihood of omitted variables bias in naive estimates motivates much of the econometric agenda in this context. Economists have also studied tracking. A recent randomized evaluation from Kenya looks at tracking as well as peer effects, finding gains from the former but contradictory evidence on the latter (Duflo, Dupas, and Kremer, 2011).

The exam schools of interest here are also associated with marked changes in peers' racial mix. In our fuzzy RD setup, which uses exam school admissions offers to construct instrumental variables for peer characteristics, enrollment compliers at Boston Latin Academy are exposed to a peer group that falls from two-thirds to 40 percent black and Hispanic, while the proportion minority falls by half, from 40 to 20, for Latin School compliers.

Changes in peer composition are not necessarily the only component of the education production function associated with changes attendance at the exam schools in our sample. Still, our research design holds many potential confounders fixed, including family background, ability, and residential sorting. The principle source of omitted variables bias, interpreted here as violations of an exclusion restriction, are changes in resources or curriculum. We argue that any bias from omission of these factors is likely to be positive, reinforcing our interpretation of the findings as offering little evidence for peer achievement or racial composition effects on state test scores, PSAT, SAT, and AP scores, or college quality. We also show that 2SLS estimates are free of omitted variables bias if other changes are themselves a consequence of peer composition. Importantly, most of the 2SLS estimates reported here are reasonably precise; we can rule out relatively modest peer composition effects.

The next section describes Boston data and school assignment. A complication here is Boston's deferred acceptance (DA) assignment algorithm. As a preliminary to the estimation of causal effects, we develop an empirical strategy that embeds DA in an RD framework.

\section{Boston Data and Admissions Process}

\subsection{Data}

We obtained registration and demographic information for BPS students from 1997-2009. BPS registration data are used to determine whether and for how many years a student was enrolled at a Boston exam school. Demographic information in the BPS file includes race, sex, and subsidized lunch, limited English proficiency, and special education status.

BPS demographic and registration information were merged with Massachusetts Comprehensive Assessment System (MCAS) scores using student identification numbers. ${ }^{6}$ The MCAS database con-

\footnotetext{
${ }^{6} \mathrm{MCAS}$ is a state-mandated series of achievement tests used to assess Adequate Yearly Progress (AYP) for purposes
} 
tains raw scores for math, English Language Arts (ELA), Writing, and Science. MCAS tests are taken each spring, typically in grades 3-8 and 10. The current testing regime covers math and English in grade 7, 8, and 10 (in earlier years, there were fewer tests). Baseline (i.e., pre-application) scores for grade 7 applicants are from 4th grade. Baseline English scores for 9th grade applicants come from 8th grade math and 7th grade English tests (the 8th grade English exam was introduced in 2006). We lose some applicants with missing baseline scores. Other outcomes include the Preliminary SAT (PSAT), the SAT Reasoning Test, and Advanced Placement exams from the College Board. For the purposes of our analysis, scores were standardized by subject, grade, and year to have mean zero and unit variance in the BPS population. Data on college enrollment come from the National Student Clearinghouse, as reported to BPS for their students.

Our analysis file combines student registration, test scores, and college outcome files with the BPS exam school applicant file. The exam school applicant file records grade, year, sending school, applicants' preference ranking of exam schools, applicants' Independent Schools Entrance Exam (ISEE) test scores, and each exam school's ranking of its applicants. It's this ranking variable that determines exam school admissions decisions.

Our analysis sample includes BPS-enrolled students who applied for exam school seats in 7th grade from 1997-2008 or in 9th grade from 2001-2007. We focus on applicants enrolled in BPS at the time of application because we're interested in how an exam school education compares to a traditional BPS education. Moreover, private school applicants are much more likely to remain outside the BPS district and hence out of our sample if they fail to get an exam school offer (about $45 \%$ of Boston exam school applicants come from private schools). The $10 \%$ of applicants who apply to transfer from one exam school to another are also omitted. Table A1 reports additional details on demographic characteristics and baseline scores for all BPS students and Boston exam school samples. The Boston data appendix explains the analysis file further, and describes test coverage and application timing in detail. Figure A1 also provides information on the determinants of the application decision, illustrating a steep gradient linking baseline MCAS scores and the decision to apply for an exam school seat. Most applicants apply to all three schools. Figure A2 shows that stronger applicants rank more selective schools more highly. ${ }^{7}$

\subsection{Exam school admissions}

Boston exam school admissions are based on the student-proposing DA algorithm, using student preferences and school-specific rankings of applicants. DA complicates RD because it loosens the direct link between the running variable and school admissions offers. Our econometric strategy therefore begins by constructing analysis samples that restore a direct link, so that offers are sharp around cutoffs. This approach seems likely to be useful elsewhere, since DA is now used for school assignment in Chicago, Denver, New York City, Newark, and in more than a hundred districts throughout England (Abdulkadiroğlu, Pathak, and Roth, 2009; Pathak and Sönmez, 2008, 2011), as well as Boston.

of No Child Left Behind (NCLB) and includes a high-stakes exit exam in 10th grade.

${ }^{7}$ Figure A1 plots application probabilities against 4th grade MCAS for a sample of non-LEP and non-special education Boston 6th graders, while Figure A2 plots the probability of ranking a school first conditional on applying. 
Boston residents interested in an exam school seat take the ISEE in the fall of the school year before they would like to transfer. We focus on those applying for seats in 7th and 9th grade (O'Bryant also accepts a handful of 10th graders). Successful 7th grade applicants transfer out of middle school, while 9th grade applicants are picking a high school. Exam school applicants also submit an official GPA report, based on grades through the most recent fall term. Finally, exam school applicants are asked to rank up to three exam schools. Each exam school running variable is a composite constructed as a weighted average of applicants' standardized math and English GPA, along with standardized scores on the four parts of the ISEE (verbal, quantitative, reading, and math).

Let $p_{i k}$ denote student $i$ 's kth choice and represent $i$ 's preference list by $\mathbf{p}_{i}=\left(p_{i 1}, p_{i 2}, p_{i 3}\right)$, where $p_{i k}=0$ if the student's rank order list is not complete. Applicants are ranked only for schools to which they've applied, so applicants with the same GPA and ISEE scores might be ranked differently at different schools depending on where they fall in each school's applicant pool. ${ }^{8}$ Let $c_{i k}$ denote student $i$ 's school- $k$ specific ranking based on $i$ 's composite score (where higher is better) and write the vector of ranks as $\mathbf{c}_{i}=\left(c_{i 1}, c_{i 2}, c_{i 3}\right)$, where $c_{i k}$ is missing if student $i$ did not rank school $k$.

Assignment is determined by student-proposing DA with student preferences over the three schools, school capacities, and students' (rank-ordered) school-specific composites as parameters. The algorithm works as follows:

Round 1: Each student applies to her first choice school. Each school rejects the lowest-ranking students in excess of its capacity, with the rest provisionally admitted (students not rejected at this step may be rejected in later steps.)

Round $\ell>1$ : Students rejected in Round $\ell-1$ apply to their next most preferred school (if any). Each school considers these students and provisionally admitted students from the previous round together, rejecting the lowest-ranking students in excess of capacity, producing a new provisional admit list (again, students not rejected at this step may be rejected in later steps.)

The algorithm terminates when either every student is matched to a school or every unmatched student has been rejected by every school he has ranked.

Let $\tau_{k}$ denote the lowest ranked student offered a seat at school $k$. We center school-specific composite ranks around this cutoff using:

$$
r_{i k}=\frac{100}{N_{k}} \times\left(c_{i k}-\tau_{k}\right)
$$

where $N_{k}$ is the number of students who ranked school $k$. Scaled school-specific ranks $r_{i k}$ equal zero at the cutoff for school $k$, with non-negative values indicating students who ranked and qualified for admission at that school. A dummy variable $q_{i}(k)=1\left[c_{i k} \geq \tau_{k}\right]$ indicates that student $i$ qualified for school $k$ by clearing $\tau_{k}$ (when $k$ is not ranked by $i, q_{i}(k)$ is zero).

\footnotetext{
${ }^{8}$ School-specific running variables arise because schools standardize GPA and ISEE scores among only their applicants, implicitly generating school-specific weights in the composite formula.
} 
Students who ranked and qualified for a school are not offered a seat at that school if they obtain an offer at a more preferred school. With three schools ranked, applicant $i$ can obtain an offer at school $k$ in three ways:

- The applicant ranks school $k$ as her top choice and qualifies: $\left(\left\{p_{i 1}=k\right\} \cap\left\{q_{i}(k)=1\right\}\right)$.

- The applicant doesn't qualify for her top choice, ranks school $k$ as her second choice, and qualifies there: $\left(\left\{q_{i}\left(p_{i 1}\right)=0\right\} \cap\left\{p_{i 2}=k\right\} \cap\left\{q_{i}(k)=1\right\}\right)$.

- The applicant doesn't qualify at her top two choices, ranks school $k$ as her third choice, and qualifies there: $\left(\left\{q_{i}\left(p_{i 1}\right)=q_{i}\left(p_{i 2}\right)=0\right\} \cap\left\{p_{i 3}=k\right\} \cap\left\{q_{i}(k)=1\right\}\right)$.

To summarize these relationships, let $O_{i}$ denote the identity of student $i$ 's offer, with the convention that $O_{i}=0$ means the student receives no offer. ${ }^{9}$ DA then produces the following offer rule:

$$
O_{i}=\sum_{j=1}^{J} p_{i j} q_{i}\left(p_{i j}\right)\left[\prod_{\ell=1}^{j-1}\left(1-q_{i}\left(p_{i \ell}\right)\right)\right]
$$

The sample for whom offers at school $k$ are sharp in the sense of being deterministically linked with $k$ 's running variable - a group we refer to as the sharp sample for school $k$ - is the union of three sets of applicants:

- Applicants who rank $k$ first, so $\left(p_{i 1}=k\right)$

- Applicants who didn't qualify for their top choice and rank $k$ second, so $\left(q_{i}\left(p_{i 1}\right)=0 \cap p_{i 2}=k\right)$

- Applicants who didn't quality for their top two choices and rank $k$ third, so $\left(\left(q_{i}\left(p_{i 1}\right)=q_{i}\left(p_{i 2}\right)=\right.\right.$ 0) $\left.\cap p_{i 3}=k\right)$.

Applicants can be in multiple sharp samples. For example, a student who ranked Boston Latin first, but did not qualify there, is also in the sharp sample for Latin Academy if Latin Academy is her second choice.

An offer dummy $Z_{i k}$ indicates applicants offered a seat at school $k$, defined separately for each school and sharp sample. This is the instrumental variable in the fuzzy RD strategy used here. Note that $Z_{i k}=0$ for a student who qualifies at $k$, but is not in the $k$ sharp sample. Within sharp samples, the discontinuity sample consists of applicants ranked in the interval $[-20,+20]$. Applicants outside this "Boston window" are well below or well above the relevant cutoffs. At the same time, the $[-20,+20]$ window is wide enough to allow for reasonably precise inference.

Figure 1A plots offers as a function of scaled composite ranks in sharp samples, confirming the sharpness of offers in these samples. Plotted points are conditional means for all applicants in a oneunit binwidth similar to the empirical conditional mean functions reported in Lee, Moretti, and Butler (2004) and a conditional mean function smoothed using local linear regression (LLR). Specifically, for

\footnotetext{
${ }^{9}$ For the purposes of this formula, we adopt the convention that $\prod_{\ell=1}^{0} a_{\ell}=1$.
} 
school $k$, data in the Boston window were used to construct estimates of $\mathrm{E}\left[y_{i} \mid r_{i k}\right]$, where $y_{i}$ is the dependent variable and $r_{i k}$ is the running variable. The LLR smoother uses the edge kernel,

$$
K_{h}\left(r_{i k}\right)=\mathbf{1}\left\{\left|\frac{r_{i k}}{h}\right| \leq 1\right\} \cdot\left(1-\left|\frac{r_{i k}}{h}\right|\right)
$$

where $h$ is the bandwidth. In a RD context, LLR has been shown to produce estimates with good properties at boundary points (Hahn, Todd, and van der Klaauw (2001) and Porter (2003)). The bandwidth used here is a version of the DesJardins and McCall (2008) bandwidth, studied by Imbens and Kalyanaraman (2010) (IK), who derive optimal bandwidths for sharp RD using a mean square-error loss function with a regularization adjustment (hereafter, DM). This DM smoother (which generates somewhat more stable estimates than the bandwidth IK prefer) is also used to construct non-parametric RD estimates, below.

In sharp samples, offers are determined by the running variable, but exam school enrollment remains fuzzy, that is, probabilistic. Specifically, not all offers are accepted. Figure 1B shows that applicants scoring just above admissions cutoffs are much more likely to enroll in a given school than are those just below, but enrollment rates among the offered are below one. Enrollment rates at other schools also change around each school-specific cutoff. Figure 1C puts these pieces together by plotting the probability of enrollment in any exam school. Overall exam school enrollment jumps at the O'Bryant and Latin Academy cutoffs, but changes little at the Latin School cutoff because those to the left of this cutoff are very likely to enroll in either O'Bryant or Latin Academy.

The effect of qualification on enrollment is detailed further in Table 1. This table reports LLR estimates of school-specific enrollment rates in the neighborhood of each school's cutoff. Among qualifying 7th grade applicants in the O'Bryant sharp sample, $72 \%$ enroll in O'Bryant, while the remaining $28 \%$ enroll in a regular BPS school. $91 \%$ of those qualifying at Latin Academy enroll there the following fall, while $93 \%$ qualifying at Latin School enroll there. Many of those not offered seats at one exam school end up in another, mostly the next school down in the hierarchy of school selectivity.

Our fuzzy RD strategy uses exam school offer dummies as instruments for exam school exposure. Table 1 therefore also describes destination schools in the relevant subpopulation of compliers associated with this approach. Here, compliers are defined as applicants to school $k$ who enroll there when offered, but go elsewhere otherwise. Complier enrollment outcomes are estimated using the IV strategy described in Abadie (2003), where a school-specific enrollment dummy is the endogenous variable. ${ }^{10}$ Column (7) of Table 1 shows that among O'Bryant compliers, the counterfactual for everyone is regular public school. Among Latin Academy compliers, the counterfactual is mostly O'Bryant, while among Latin School compliers, the counterfactual is mostly Latin Academy. This serves to highlight the progressive nature of the Boston exam school "experiment": only among O'Bryant compliers do we get to compare exam school and traditional public school directly. At the same time, as we show below, movement up the ladder of exam school selectivity in both cities is associated with dramatic

\footnotetext{
${ }^{10}$ Specifically, compliers are defined as follows. Let $D_{1 i}$ denote exam school enrollment status when the instrument $Z_{i}$ is switched on and $D_{0 i}$ denote exam school enrollment status when the instrument $Z_{i}$ is switched off. Compliers have $D_{1 i}=1$ and $D_{0 i}=0$. Although the compliant population cannot be enumerated, characteristics of this population are non-parametrically identified and easily estimated.
} 
changes in peer composition.

\subsection{The Exam School Environment}

The peer achievement first stage behind our fuzzy RD identification strategy is described in Figure 2A. This figure plots peer mean baseline math scores for applicants in the sharp sample who are on either side of admissions cutoffs (the peer mean is the average baseline score of same-grade peers in the school enrolled in the year following the year of exam-school application). Baseline peer means jump by roughly half a standard deviation at each admissions cutoff. In other words, among already positively selected exam school applicants, peers at Latin Academy are ahead of non-exam BPS peers by a full standard deviation, while peers at Latin School are ahead of non-exam BPS peers by about $1.5 \sigma$. The jump in peer mean ELA scores (not shown) is similar to that for math.

The proportion nonwhite among exam school students has often been a lightning rod for controversy. Beginning in the 1970s, Boston's court-mandated desegregation plan maintained the proportion black and Hispanic in exam schools at roughly 35\%. Racial preferences were challenged in 1996, however, and Boston exam school admissions have ignored race since 1999 (Boston Public Schools, 2007). In our sample, drawn from years after racial preferences were abandoned, the proportion of black and Hispanic peers drops sharply at exam school cutoffs, a fact documented in Figure 2B. The proportion non-white falls by about 10 percentage points at the O'Bryant cutoff, with even larger drops at the Latin Academy and Latin School cutoff, on the order of 25 percent.

Additional features of the exam school environment are summarized in Table 2, focusing on enrollment compliers as in columns (7)-(9) of Table 1. Table 2 documents marked shifts in peer achievement and racial composition captured graphically in Figure 2. Other contrasts between the exam school environment and regular public schools are less systematic. Class sizes for middle school applicants tend to be larger at exam schools, but differences in size shrink in grade 9 and change little at the Latin School cutoff. Likewise (see Table 7 below), among New York schools, only the Bronx Science cutoff induces an marked increase, while class size falls slightly at Stuyvesant. Exam school teachers tend to be older than regular public school teachers, as can be seen at the O'Bryant cutoff, but teacher age changes little at the Latin Academy and Latin School cutoffs.

The large and systematic changes in peer composition at each cutoff and entry point motivate our focus on peers as the primary mediator of the exam school treatment. Before turning to a 2SLS analysis that treats peer composition as the primary causal channel for exam school effects, however, we begin with reduced form estimates.

\section{Reduced Form Achievement Effects}

\subsection{Boston Estimates}

We constructed parametric and non-parametric RD estimates of the effect of an exam school offer

using the normalized composite rank as the running variable. We refer to this initial set of estimates as "reduced form" because they capture the overall effect of an exam school offer, without adjustment 
for the relationship between offers and mediating variables. As noted in the recent RD survey by Lee and Lemieux (2010), parametric and non-parametric approaches are complementary, providing a mutually reinforcing specification check.

The parametric estimating equation for applicants in the sharp sample at school $k$ is

$$
y_{i t k}=\alpha_{t k}+\sum_{j} \delta_{j k} d_{i j}+\left(1-Z_{i k}\right) f_{0 k}\left(r_{i k}\right)+Z_{i k} f_{1 k}\left(r_{i k}\right)+\rho_{k} Z_{i k}+\eta_{i t k}
$$

where the variable $Z_{i k}$ is an indicator for $c_{i k} \leq \tau_{k}$ and the coefficient of interest is $\rho_{k}$. Equation (2) controls for test year effects at school $k$, denoted $\alpha_{t k}$, and for the year and grade of application, indicated by dummies, $d_{i j}$. (These are included for consistency with some of the over-identified 2SLS models discussed below. $)^{11}$ The effects of the running variable at school $k$ are controlled by a pair of third-order polynomials that differ on either side of the cutoff, specifically

$$
f_{j k}\left(r_{i k}\right)=\pi_{j k} r_{i k}+\xi_{j k} r_{i k}^{2}+\psi_{j k} r_{i k}^{3} ; \quad j=0,1
$$

Non-parametric estimates differ from parametric in three ways. First, they narrow the Boston window when the optimal data-driven bandwidth falls below $20 .{ }^{12}$ Second, our non-parametric estimates use a tent-shaped edge kernel centered at admissions cutoffs instead of the uniform kernel implicit in parametric estimation. Finally, non-parametric models control for linear functions of the running variable only, omitting higher-order terms. We can write the non-parametric estimating equation as

$$
\begin{aligned}
y_{i t k} & =\alpha_{t k}+\sum_{j} \delta_{j k} d_{i j}+\gamma_{0 k}\left(1-Z_{i k}\right) r_{i k}+\gamma_{1 k} Z_{i k} r_{i k}+\rho_{k} Z_{i k}+\eta_{i t k} \\
& =\alpha_{t k}+\sum_{j} \delta_{j k} d_{i j}+\gamma_{0 k} r_{i k}+\gamma_{k}^{*} Z_{i k} r_{i k}+\rho_{k} Z_{i k}+\eta_{i t k}
\end{aligned}
$$

for each of the three schools indexed by $k$. Non-parametric RD estimates come from a kernel-weighted least squares fit of equation (4).

\section{MCAS Scores}

Except in the plots for 10th grade English, which show jumps at two out of three cutoffs, visual reduced forms offer little evidence of marked discontinuities in MCAS scores. This can be seen in in Figures $3 \mathrm{~A}$ and $3 \mathrm{~B}$ for middle school and Figures $4 \mathrm{~A}$ and $4 \mathrm{~B}$ for high school. Jumps in smoothed scores at admissions cutoffs constitute non-parametric estimates of the effect of an exam school offer in the sharp sample. The corresponding estimates, reported in Table 3, tell the same story. Few of the estimates are significantly different from zero and some of the significant effects at Latin School are negative (for example, Latin School effects on 10th grade math and middle school English). Most of the estimates are small and some are precise enough to support a conclusion of no effect.

\footnotetext{
${ }^{11}$ The over-identified 2SLS models discussed in Section 5 use interactions between exam offer and applicant cohort as additional instruments.

${ }^{12}$ The DM bandwidths for Table 3 range from about 9.6 to 36.9 .
} 
In an effort to increase precision, we also constructed estimates pooling applicants to all three Boston exam schools. The pooled estimating equations are the same as equations (2) and (4), but with a single offer effect, $\rho$. These specifications interact all control variables, including running variables, with application-school dummies. ${ }^{13}$ The kernel weight for the stack becomes $K_{h_{k}}\left(r_{i k}\right)$ where school $k$ 's bandwidth $h_{k}$ is estimated separately in a preliminary step. Because the pooled model includes a full set of main effects and interactions for school-specific subsamples, we can think of the estimate of $\rho$ in this stack as a variance-of-treatment-weighted average of school-specific estimates. ${ }^{14}$ Note that some students appear in more than one sharp sample; each student contributes up to three observations for each outcome. Our inference framework takes account of this by clustering standard errors by student.

Paralleling the pattern shown in the Boston reduced form figures, offer effects from the stacked models, reported in columns labeled "All Schools" in Table 3, are mostly small, with few significantly different from zero. ${ }^{15}$ The large significant estimate for 10th grade English scores, a result generated by both parametric and non-parametric models, is partly offset by marginally significant negative effects on 7th and 8th grade English, so that when all scores are pooled the overall estimate is close to zero (scores from different years and grades are stacked in much the same way that schools are stacked). Importantly, the combination of school- and score-pooling generates precise estimates, with standard errors on the order of 0.027 for math and 0.028 for English.

Estimates for black and Hispanic applicants to exam schools, reported in appendix Table A4, are in line with the full-sample findings for math and middle-school ELA scores. Also, consistent with the full-sample results for 10th grade ELA, an exam school education seems especially likely to boost 10 th grade English scores for blacks and Hispanics, with an estimated effect of $0.17 \sigma$, but there are some significant negative estimates as well.

Appendix A reports results from an exploration of possible threats to a causal interpretation of the reduced form estimates in Table 3. Specifically we look for differential attrition (i.e., missing score data) to the right and left of exam school cutoffs (see Table A2) and for discontinuities in covariates (see Table A3). Receipt of an exam school offer makes attrition somewhat less likely, but the gaps are small and unlikely to impart substantial selection bias in estimates that ignore them. ${ }^{16}$ A handful of covariate contrasts also pop up as significantly different from zero, but the spotty nature of these gaps seem consistent with the notion that comparisons to the left and right of exam school admissions cutoffs are indeed a good experiment.

A related threat to validity comes from the possibility that marginal students switch out of exam schools at an unusually high rate. If school switching is harmful, excess switching might account for findings showing little in the way of score gains. As it turns out, however, exam school applicants who clear admissions cutoffs are less likely to switch through grade 12 than are traditional BPS students.

\footnotetext{
${ }^{13}$ In the stacked analysis, an observation from the sharp sample for school $k$ is associated with the running variable for that school. Other running variables are switched off for that observation by virtue of the interactions.

${ }^{14}$ Variance-weighting is a property of regression models with saturated controls; see, e.g., Angrist (1998).

${ }^{15}$ Unreported estimates for HS MCAS Science tests offer little evidence of positive effects.

${ }^{16}$ Lee (2009) bounds confirm this. Also worth noting is the fact that F-tests for the joint significance of differential attrition in MCAS reduced forms generate p-values of about 0.2 or higher.
} 
The impact on 9-12 persistence increases by about around 6 percentage points for successful 9th grade applicants, while 7-12 persistence increases by 25 percent among 7 th grade applicants, though this later increase is due in part to the fact that exam school students do not switch schools in grade $9 .{ }^{17}$

\section{High Achievers}

In effort to provide additional evidence on effects across quantiles of the applicant ability distribution, we exploit the fact any single test is necessarily a noisy measure of ability. Although we can't construct (non-parametric) RD estimates for, say, O'Bryant students with ISEE scores in the upper tail of the score distribution, we can look separately at subsamples of students with especially high baseline MCAS scores. This approach operationalizes a suggestion in Section 3.3 of Lee and Lemieux (2010)'s recent survey of $\mathrm{RD}$ methods, which points out that a test score running variable can be seen as a noisy measure of an underlying ability control. Here, we exploit the fact that some in the high-baseline group are ultra-high achievers who earned marginal ISEE scores by chance.

The average baseline score for students in the upper half of the baseline MCAS distribution (among all applicants) hovers around 1.2-1.4 $\sigma$ in both math and English. Table 4 shows that this is remarkably close to the average baseline achievement level among students enrolled in exam schools. Importantly, MCAS scores remain informative even for these high achievers: no more than one third top out in the sense of testing at the Advanced (highest) MCAS proficiency level. Likewise, MCAS remains informative even for applicants in the upper baseline MCAS quartile, where average baseline scores are $0.5-0.6 \sigma$ beyond those of the average among students enrolled in exam schools at grade 7 . (Note also that applicants in these groups are exposed to almost exactly the same changes in peer composition as applicants in the full sample.)

Perhaps surprisingly, RD estimates for applicants in the upper half and upper quartile of the baseline score distribution come out similar to those for the full sample. These results, reported in columns (3) and (5) of Table 4, are mostly negative with few significantly different from zero. The exception again is a significant positive effect for 10th grade ELA. At the same time, the sample of high achievers generates a significant negative estimate of effects on middle school ELA - an effect of roughly the same magnitude as the positive ELA estimate for 10th graders. Thus, even in a sample of ultra high (baseline) achievers, there is little evidence of a consistent exam school boost.

\section{PSAT, SAT, and AP Exam Scores}

With the exception of the 10th grade test that also serves an as an exit exam, MCAS scores are only indirectly linked to ultimate educational attainment. We therefore look at other indicators of human capital and learning. The first of these is the PSAT, which serves as a warmup for the SAT and is used in the National Merit scholarship program; the second is the SAT. ${ }^{18}$

\footnotetext{
${ }^{17}$ These estimates come from a non-parametric reduced form analysis similar to that used to construct the covariate balance and attrition estimates in the appendix.

${ }^{18}$ The correlation between 10th grade MCAS math and PSAT or SAT is about 0.7 ; the correlation for English is similar. These estimates come from models that control for application cohort and grade, test year, and demographics (race, gender, free lunch).
} 
SAT and PSAT tests are usually taken towards the end of high school, so scores are unavailable for the youngest applicant cohorts in our sample (appendix Table C2 lists the cohorts contributing to each analysis sample). In March 2005, the College Board added a writing section to the SAT. Since the writing section does not appear in earlier years, we focus on the sum of Critical Reading (Verbal) and Mathematics scores, also known as the SAT Reasoning score. The average PSAT score for applicants in the Boston window (Critical Reading and Math) is 91.3, while the average SAT score is 1019. These can be compared with 2010 national average PSAT and SAT scores of 94 and 1017. As with MCAS outcomes, PSAT and SAT scores are standardized to have mean zero and unit variance among all test-takers in a given year.

About 70-80 percent of exam school applicants take the PSAT. O'Bryant offers increase PSAT taking by about 6 points, but the estimated impact is zero in the All Schools models. These results can be seen in Panel A of Table 5. Panel B of this table shows that exam school offers have no impact on the likelihood applicants take the SAT. Selection bias in the sample of test takers therefore seems unlikely to be a concern. Consistent with the MCAS results, there is no gain in either PSAT or SAT results for test-takers near admissions cutoffs.

Motivated by the prevalence of AP courses in the Boston exam school curriculum, we estimated exam school effects for AP participation rates and scores. As with the PSAT/SAT analysis, younger cohorts are excluded since these tests are usually taken in grades 11-12 (again, appendix Table C2 gives details). AP tests are scored on a scale of 1-5, with some colleges granting credit for subjects in which an applicant scores at least 3 or 4 . At the high end, Latin School students take an average of three to four AP exams.

Table 5 reports estimated AP effects on scores summed over all AP exams, as well as for a subset of the most popular exams, defined as those taken by at least 500 students in our BPS score file. This restriction narrows the set of exams to include widely-assessed subjects like math, science, english, history, and economics, but omits music and art. ${ }^{19}$ Exam school offers fail to increase the number of tests taken, though the sum of scores goes up at O'Bryant. The sum of scores on the most commonly taken and probably the most substantively important tests are unaffected by exam school qualification. ${ }^{20}$

\section{Post-Secondary Outcomes}

BPS matches data on seniors to National Student Clearinghouse (NSC) files, which record information on enrollment at over 90 percent of American 4-year colleges and universities (coverage details appear in Appendix Table C5). We used the BPS-NSC match to look at college attendance, excluding postsecondary institutions that focus on technical and vocational training. Most Boston exam school applicants go to college; roughly 60 percent to the left of the O'Bryant cutoff, and 90 percent to the

\footnotetext{
${ }^{19}$ Tests with at least 500 takers are Calculus AB/BC, Statistics, Biology, Chemistry, Physics B/C, English Language and Composition, English Literature and Composition, European History, US Government and Politics, US History, Microeconomics, and Macroeconomics.

${ }^{20}$ There is also no evidence that exam offers increase test-taking on AP science, technology, engineering, and mathematics fields.
} 
right of the Latin School cutoff. At the same time, Table 6, which reports estimated effects on postsecondary outcomes, shows little evidence of an exam school treatment effect on college enrollment or quality. $^{21}$

\subsection{New York Estimates}

First stage and reduced form estimates for New York are presented in a format like that used for Boston. New York data come from three sources: enrollment and registration files containing demographic information and attendance records; application and assignment files; and the Regents exam file. Our analysis covers four 9th grade applicant cohorts (from 2004-2007), with follow up test score information through 2009. The New York data appendix explains how these files were processed.

The New York exam school admissions process is simpler than the Boston process because selection is based solely on the Specialized High School Achievement Test (SHSAT), whereas Boston schools rely on school-specific composites. New York 8th graders interested in an exam school seat take the SHSAT and submit an application listing school preferences (we omit a handful of 9th grade applicants). Students are ordered by SHSAT scores. Seats are then allocated down this ranking, with the top scorer getting his first choice, the second highest scorer get his most preferred choice among schools with remaining seats, and so on. There is no corresponding "sharp sample" for New York exam school applicants, since New York applicants rank many schools, both exams and others, and we have no information on rankings beyond the fact of an application. ${ }^{22}$

New York admissions are based on a single underlying running variable, unlike the school-specific running variables in Boston. As in Boston, however, we standardized and centered the running variable separately for each New York school. Stuyvesant is the most competitive exam school, so the minimum score needed to obtain an offer exceeds the minimum at Bronx Science and Brooklyn Technical. School-specific running variables are constructed as in Boston (equation 1). These normalized running variables equal zero at each cutoff, with positive values indicating applicants offered a seat. Also as in Boston, applicants might qualify for placement at one school, but rank a less competitive school first and get an offer at that school instead.

New York cutoffs are typically separated by six standardized rank units, so the estimation window for each of the New York schools is set at $[+6,-6]$. The New York window is narrower than the Boston window of $+/-20$ but still includes many more applicants.

Figure 5A shows how New York offers are related to the running variable. Here, the dots indicate averages in half-unit bins, while smoothing uses LLR with the DM bandwidth generated in the estimation sample. Own-school offers jump at each cutoff. Unlike in Boston, however, offer rates among qualified applicants are less than one because the sample here is not sharp; that is, some New York

\footnotetext{
${ }^{21}$ Selectivity is defined by Barron's. Boston University and Northeastern University are examples of "Highly Competitive" schools. The University of Massachusetts-Boston and Emmanuel College are "Competitive."

${ }^{22}$ The NYC exam school assignment mechanism is a serial dictatorship with students ordered by SHSAT score. Students apply for exam schools at the same time that they rank regular New York high schools, and may receive offers from both. Abdulkadiroğlu, Pathak, and Roth (2009) describe how exam school admissions interact with admissions at regular high schools. In the notation introduced in Section 3, the information available for New York is $Z_{i k}$, but the underlying orderings $\mathbf{p}_{i}$ are not.
} 
applicants who qualify at the focal school in each panel have ranked another school at which they qualify higher. Five or six points to the right of the Brooklyn Tech and Bronx Science cutoffs, offers at the next most selective exam school up replace those at the focal school in each panel.

Offers at each exam school lead to enrollment at that school, though the offer-to-enrollment conversion rate differs across schools. This pattern is documented in Figure 5B. The enrollment jumps at the Brooklyn Tech and Bronx Science cutoffs are lower than the corresponding offer jumps, though both of these enrollment jumps remain substantial. The Stuyvesant enrollment jump is about as large as the offer jump, implying that nearly all applicants offered a seat at Stuyvesant choose to enroll there.

New York has considerable school choice, with other selective schools outside the set of traditional exam schools. Admission to one of the three traditional exam schools schools is nevertheless associated with a sharp jump in peer achievement, as can be seen in Figure 6A. The average baseline math score of peers increases by about $0.5 \sigma$ at the Brooklyn Tech cutoff. The jump is smaller for Bronx Science and Stuyvesant, though still substantial at about 0.2 $\sigma$. Peer means for English move similarly. As at Boston's exam school cutoffs, qualification for a New York exam school induces a sharp drop in the proportion of peers who are nonwhite. This can be seen in Figure 6B, which shows a 20 percentage point drop at Brooklyn Tech, and 10 percentage point drops at Bronx Science and Stuyvesant.

New York's exam schools expose successful applicants to a number of changes in school environment, but here too the largest and most consistent changes involve peer achievement and race. This can be seen in Table 7, which characterizes the changes in school environment experience by New York exam school enrollment compliers. Class size changes less at New York exam school cutoffs than at Boston's.

Finally, like Boston, reduced form estimates for New York offer little evidence that exam schools boost achievement. This is apparent in Figures 7A and 7B, which plot performance on the Advanced Math and English components of the New York Regents exam against the standardized New York running variables. This pattern is echoed in Table 8, which reports parametric and DM estimates of offer effects on Advanced Math and English as well as for other Regents test outcomes. The estimates here come from equations similar to $(2)$ and (4) fit to samples of New York applicants in a $[-6,+6]$ interval. These estimates are precise enough to rule out even modest score gains. For example, the DM estimate of the effect on English scores in the stacked sample is $0.01 \sigma$, with a standard error also around 0.01. The few significant pooled estimates in Table 8 are negative.

\section{Peers in Education Production}

The reduced form estimates reported here show little evidence of an impact of exam school offers on test scores and post-secondary outcomes. Exam school offer effects are relevant for policy questions related to exam school expansion, including contemporary proposals to lower admissions cutoffs and increase the number of exam school seats. ${ }^{23}$ At the same time, we're also interested in the general

\footnotetext{
${ }^{23}$ Vaznis (2009) discusses efforts to add 6th grade cohorts at Boston exams, while Hernandez (2008) reports on proposals to increase minority representation at New York's exam schools. Further afield, Lutton (2012) describes a proposed exam
} 
lessons that might emerge from an exam school analysis.

What is the exam school treatment? An overall change in school quality is hard to document or even define, but it's clear that exam school students gain the opportunity to study with high-achieving achieving peers. The peer achievement effects documented here emerge at each exam school admissions cutoff. In other words, each cutoff induces a "peer achievement experiment," in spite of the fact that overall exam school admission probabilities jump markedly only at cutoffs for the least selective schools (O'Bryant in Boston and Brooklyn Tech in New York). Jumps in peer achievement allow us to identify causal peer effects. Moreover, because the six exam school cutoffs under consideration intersect the applicant ability distribution over a wide range, we're in a position to consider the extent to which peer effects interact with applicants' own ability.

In addition to manipulating peer achievement, admissions cutoffs induce a sharp change in racial composition, with large shifts at each cutoff. The exam school racial mix partly reflects the selective admissions policies that drive peer achievement. Because white applicants have higher test scores than do nonwhites (in this case, black and Hispanic applicants), the enrolled population is disproportionately white. Successful exam school applicants therefore receive the same sort of treatment generated by our imaginary voucher experiment for Waltham homeowners on the Newton line: the opportunity to attend school with fewer minority as well as higher-achieving classmates. These observations lead to 2SLS specifications that take peer characteristics as the primary causal channel mediating exam school offer effects.

The 2SLS estimates of peer achievement and racial composition effects reported here come from specifications and samples paralleling those used for the pooled reduced form estimates reported in Table 3 and 8 (pooling applicant grades and test years, as well as schools). All controls, including year and grade of test, application cohort effects, and own- and other-school running variable controls, are subsumed in a vector $X_{i t j}$, with conformable coefficient vector $\Gamma_{j}$. The 2SLS second stage can then be written,

$$
y_{i t j}=\Gamma_{j}^{\prime} X_{i t j}+\theta p_{i t}+\epsilon_{i t j}
$$

where $p_{i t}$ are the endogenous variables to be instrumented and $\theta$ is the causal effect of interest. The corresponding first stage equations include the same controls plus offer dummies as excluded instruments.

A simple causal model of education production facilitates interpretation of 2SLS estimates of equation (5). Let $m_{i}$ denote a $k$-dimensional vector of education inputs measured in the exam school entry grade. These include peer achievement and race, measures of school quality, and teacher effects. Our goal is to identify the causal impacts of variation in a subset of these inputs at a specific point in the education profile, holding earlier inputs and family background fixed. ${ }^{24}$ A parsimonious representation

\footnotetext{
school expansion in Chicago.

${ }^{24}$ Todd and Wolpin (2003) discuss the conceptual distinction between this type of interruption-based causal relationship and a complete cumulative education production function.
} 
of the education production function is:

$$
y_{i}=\pi^{\prime} m_{i}+\eta_{i}
$$

where $\eta_{i}$ is the random part of potential outcomes under alternative assignments of the input bundle, $m_{i}$. We partition $m_{i}$ into observed peer achievement and racial composition, denoted $p_{i}$, and $k-2$ unobserved inputs, $w_{i}$. That is,

$$
m_{i}=\left[p_{i}^{\prime} w_{i}^{\prime}\right]^{\prime}
$$

so that

$$
y_{i}=\beta^{\prime} p_{i}+\gamma^{\prime} w_{i}+\eta_{i}
$$

where $w_{i}$ is defined so that $\gamma$ is positive.

The $q \times 1(q \geq 2)$ instrument vector in this context, $z_{i}$, indicates exam school offers. Offers are assumed to be independent of potential outcomes $\left(\eta_{i}\right)$, without necessarily satisfying an exclusion restriction. In other words, exam school offers, taken to be as good as randomly assigned in a nonparametric RD setup, lead to exam school enrollment, which in turn changes peer characteristics and perhaps other features of the school environment, denoted by $w_{i}$. We summarize these changes through the following first-stage relationships:

$$
\begin{aligned}
p_{i} & =\theta_{1}^{\prime} z_{i}+\nu_{1 i} \\
w_{i} & =\theta_{2}^{\prime} z_{i}+\nu_{2 i},
\end{aligned}
$$

where first-stage residuals are orthogonal to the instruments by construction, but possibly correlated with $\eta_{i}$. The proposition below characterizes the causal effects captured by 2SLS given this structure:

Proposition 1. 2SLS estimates using $z_{i}$ as an instrument for $p_{i}$ in (6) omitting $w_{i}$ identify $\beta+\delta^{\prime} \gamma$, where $\delta$ is the population 2SLS coefficient vector from a regression of $w_{i}$ on $p_{i}$, using $z_{i}$ as instruments.

This is a 2SLS version of the omitted variables bias formula (see, for example, Angrist and Krueger, 1992). Proposition 1 implies that if $\delta$ is positive (because exam schools have better unmeasured inputs), 2SLS estimates of peer effects omitting $w_{i}$ tend to be too big. The notion that omitted variables are likely to be beneficial seems reasonable in this context; among other distinctions, Boston and New York exam schools feature, to varying degrees, a rich array of course offerings, relatively modern facilities, and a challenging curriculum meant to prepare students for college.

An alternative interpretation under somewhat stronger assumptions is based on the notion that any input correlated with exam school offers is itself caused by $p_{i}$. In other words, the relationship between $w_{i}$ and exam school offers is a result of the effect of exam school attendance on peer characteristics (exam school curricula are challenging because exam school students are high-achieving; the prevalence of nonwhite students affects course content). Suppose the causal effect of $p_{i}$ on $w_{i}$ is described by a 
linear constant effects model with coefficient vector $\lambda$. Then we have,

$$
\begin{aligned}
w_{i} & =\lambda p_{i}+\xi_{i}, \\
E\left[z_{i} \xi_{i}\right] & =0 .
\end{aligned}
$$

This assumption generates a triangular structure which implies that 2SLS estimates combine both the direct and indirect effects of peers, as described in Proposition 2:

Proposition 2. Given (7), 2SLS using $z_{i}$ as the instrument vector for $p_{i}$ in (6) omitting $w_{i}$ identifies $\beta+\lambda^{\prime} \gamma$, the sum of direct and indirect effects of peers, with no omitted variables bias.

Proposition 2 is a consequence of the fact that under assumption (7), $\delta$ becomes $\lambda$, the causal effect of $p_{i}$ on $w_{i}$. When other inputs are causally downstream to peer characteristics, 2SLS estimates of peer effects omitting $w_{i}$ capture the total impact of randomly assigning $p_{i}$.

\section{Estimates}

To maximize precision and to facilitate exploration of models with multiple endogenous variables, we constructed 2SLS estimates using a combined Boston and New York sample, with six offer dummies as instruments. The 2SLS specifications parallel those used to construct the single-city stacked (reduced form) estimates, except that the stack now includes six schools. In addition to estimates using one offer dummy for each school as instruments, we also report 2SLS estimates from more heavily over-identified models adding interactions between offers and applicant cohort to the instrument list.

Table 9 reports first-stage estimates and the associated F statistics (adjusted, where appropriate, for multiple endogenous variables), as well as second stage estimates. Consistent with the figures, the first stage estimates show large, precisely estimated offer effects on on peer achievement and racial composition. For example, an O'Bryant offer increases average baseline peer scores by over two-thirds of a standard deviation, while the peer achievement gain is about $0.4 \sigma$ at the Latin Academy cutoff, and $0.6 \sigma$ at the Latin School cutoff. Peer achievement also shifts sharply at New York cutoffs, though less than in Boston. First-stages for racial composition show that offers induce a 12-24 percentage point reduction in the proportion of non-white classmates at each Boston cutoff, and a 7-13 percentage point reduction in New York.

Consistent with the reduced form offer estimates discussed in the previous section, 2SLS estimates treating peer achievement as the single endogenous variable show no evidence of a statistically significant peer effect. Importantly, however, the 2SLS estimates and the associated standard errors in Table 9 , on the order of 0.03 , also provide a basis for comparisons. For example, these estimates allow us to reject the corresponding large positive OLS estimates of peer effects reported as a benchmark in our working paper, Abdulkadiroğlu, Angrist, and Pathak (2011)). The small peer effects in Table 9 are also significantly different from estimates of conceptually similar achievement peer effects reported elsewhere. Examples include Hoxby (2000) (0.3-0.5 ), Hanushek, Kain, Markman, and Rivkin (2003)

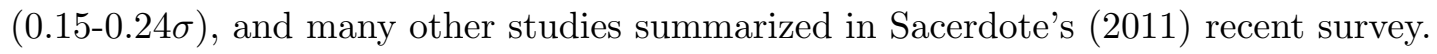


2SLS estimates of racial composition effects, reported in columns (2) and (7), likewise show no statistically significant evidence of a substantial impact, though these are less precisely estimated than the corresponding peer achievement effects. At the same time, we can easily rule out large negative effects of proportion nonwhites. (Compare, for example, Hoxby (2000), which reports estimates ranging from -1 to -2 for black and Hispanic third graders).

Models with two endogenous variables capture pairs of causal effects at the same time. These models, identified by variation at 6 admissions cutoffs, allow for the possibility that causal channels are reinforcing or offsetting in a scenario where both vary. We also introduce a secular exam school effect parameterized as operating through years of exam school enrollment. The secular enrollment effect provides a simple adjustment for possible violations of the exclusion restriction in models with specific causal channels. Results from models with multiple endogenous variables are naturally less precise than the estimates generated by models with a single channel. Except possibly for a marginally significant positive effect of proportion nonwhite on math scores in column (3), multiple-endogenousvariable estimates are consistent with those generated by models allowing only a single causal channel.

\section{Summary and Conclusions}

The results reported here suggest an exam school education produces only scattered gains for applicants, even among students with baseline scores close to or above the mean in the target school. Because the exam school experience is associated with sharp increases in peer achievement, these results weigh against the importance of peer effects in the education production function. Our results also fail to uncover systematic evidence of racial composition effects. The outcome most strengthened by exam school attendance appears to be the 10th grade ELA score, a result driven by gains for minorities. Given the history of racial preferences (and their more recent elimination) in Boston's exam schools, this finding seems worth further exploration. Overall, however, while the exam school students in our samples clearly have relatively good outcomes, most of these students would likely have done well without the benefit of an exam school education.

Of course, test scores and peer effects are only part of the story. It may be that preparation for exam school entrance is itself worthwhile. The RD design captures the impact of peer composition and possibly other changes at admissions cutoffs, while ignoring effects common to applicants on both sides. Likewise, unique features of an exam school education may boost achievement in specific areas. Students who attend Boston Latin School almost certainly learn more Latin than they would have otherwise. The many clubs and activities at some exam schools may expose students to ideas and concepts not easily captured by achievement tests or our post-secondary outcomes. It's also possible that exam school graduates earn higher wages, a question we plan to explore in future work. Still, the estimates reported here suggest any labor market gains come through channels other than peer composition and increased cognitive achievement.

Our results are relevant to the economic debate over school choice, as developed in analyses by Kane and Staiger (2002), Hastings, Kane, and Staiger (2009), Hsieh and Urquiola (2006), Rothstein (2006), and MacLeod and Urquiola (2009), among others. As with the jump in house prices at district 
boundaries, heavy rates of exam school over-subscription suggest that parents believe peer composition matters a great deal. The fact that we can largely rule out achievement gains from peer composition suggests that parents either mistakenly equate attractive peers with high value added, or that they value exam schools for reasons other than their impact on learning. Both of these scenarios reduce the likelihood that school choice has strong salutary demand-side effects on education production.

Finally, our study makes a number of methodological contributions. As school choice has proliferated, so too has the use of sophisticated assignment mechanisms such as deferred acceptance. We've shown how to craft a sharp regression discontinuity design from a deferred-acceptance allocation of students to schools. In the spirit of a suggestion by Lee and Lemieux (2010), we've also shown how the presence of a second running variable with substantive content similar to the operational running variable facilitates an exploration of the external validity of regression discontinuity estimates. 
Table 1. Boston and New York School Choices

\begin{tabular}{|c|c|c|c|c|c|c|c|c|c|}
\hline & \multicolumn{6}{|c|}{ All Applicants } & \multicolumn{3}{|c|}{ Compliers } \\
\hline & \multicolumn{2}{|c|}{ O'Bryant } & \multicolumn{2}{|c|}{ Latin Academy } & \multicolumn{2}{|c|}{ Latin School } & \multirow{3}{*}{$\begin{array}{c}\text { O'Bryant } \\
\mathrm{Z}=0 \\
(7) \\
\end{array}$} & \multirow{3}{*}{$\begin{array}{c}\text { Latin Academy } \\
Z=0 \\
(8) \\
\end{array}$} & \multirow{3}{*}{$\begin{array}{c}\text { Latin School } \\
\mathrm{Z}=0 \\
(9) \\
\end{array}$} \\
\hline & $\mathrm{Z}=0$ & $\mathrm{Z}=1$ & $Z=0$ & $\mathrm{Z}=1$ & $\mathrm{Z}=0$ & $\mathrm{Z}=1$ & & & \\
\hline & & & & $(4)$ & $(5)$ & $(6)$ & & & \\
\hline & \multicolumn{9}{|c|}{ Panel A. Boston 7th Grade Applicants } \\
\hline Traditional Boston public schools & 1.00 & 0.28 & 0.24 & 0.09 & 0.08 & 0.05 & 1.00 & 0.16 & 0.03 \\
\hline O'Bryant & 0.00 & 0.72 & 0.75 & 0.00 & 0.06 & 0.00 & $\ldots$ & 0.83 & 0.06 \\
\hline Latin Academy & 0.00 & 0.00 & 0.00 & 0.91 & 0.86 & 0.01 & 0.00 & $\ldots$ & 0.91 \\
\hline \multirow[t]{2}{*}{ Latin School } & $\ldots$ & $\ldots$ & $\cdots$ & $\ldots$ & 0.00 & 0.93 & $\cdots$ & $\ldots$ & $\ldots$ \\
\hline & \multicolumn{9}{|c|}{ Panel B. Boston 9th Grade Applicants } \\
\hline Traditional Boston public schools & 1.00 & 0.34 & 0.28 & 0.14 & 0.15 & 0.04 & 1.00 & 0.16 & 0.12 \\
\hline O'Bryant & 0.00 & 0.66 & 0.72 & 0.00 & 0.00 & 0.00 & $\ldots$ & 0.82 & 0.00 \\
\hline Latin Academy & $\ldots$ & $\ldots$ & 0.00 & 0.87 & 0.86 & 0.02 & $\ldots$ & $\ldots$ & 0.88 \\
\hline \multirow[t]{3}{*}{ Latin School } & $\ldots$ & $\ldots$ & 0.00 & -0.01 & 0.00 & 0.94 & $\ldots$ & 0.01 & $\ldots$ \\
\hline & \multirow{2}{*}{\multicolumn{2}{|c|}{ Brooklyn Tech }} & \multirow{2}{*}{\multicolumn{2}{|c|}{ Bronx Science }} & \multirow{2}{*}{\multicolumn{2}{|c|}{$\begin{array}{l}\text { Stuyvesant } \\
\text { NYC 9th }\end{array}$}} & Brooklyn Tech & Bronx Science & Stuyvesant \\
\hline & & & & & & & Panel C. NYC 9th Grade Applicants & & \\
\hline Traditional NYC public schools & 0.74 & 0.36 & 0.49 & 0.22 & 0.15 & 0.09 & 0.86 & 0.72 & 0.12 \\
\hline Brooklyn Tech & 0.10 & 0.54 & 0.39 & 0.30 & 0.25 & 0.08 & $\ldots$ & 0.23 & 0.32 \\
\hline Bronx Science & 0.02 & 0.00 & 0.02 & 0.39 & 0.43 & 0.17 & 0.04 & $\ldots$ & 0.50 \\
\hline Stuyvesant & 0.03 & 0.01 & $\ldots$ & $\ldots$ & 0.08 & 0.63 & 0.04 & $\ldots$ & $\ldots$ \\
\hline \multicolumn{10}{|c|}{$\begin{array}{l}\text { Notes: This table describes the destination schools of exam school applicants in Boston and New York. Columns } 1-6 \text { show enrollment rates to the left }(Z=0) \text { and right }(Z=1) \text { of each } \\
\text { exam school admission cutoff. Enrollment rates are measured in the fall admissions cycle following exam school application and estimated using local linear smoothing. Columns } 7-9 \\
\text { show enrollment destinations when not offered a seat, for enrollment compliers only. Enrollment compliers are applicants who attend the target exam school when offered a seat. Panels } \\
\text { A and B report distributions for Boston applicants in } 7 \text { th and 9th grade. Panel C reports distributions for 9th grade applicants to NYC schools. The Boston } 7 \text { th grade sample includes } \\
\text { students who appliedfor admission from 1999-2008. The Boston 9th grade sample includes students who applied for admission from } 2001-2007 \text {. The NYC sample includes students } \\
\text { who applied for admission from 2004-2007. Boston calculations are for the sharp sample of applicants who are offered a seat at the target school when they qualify. }\end{array}$} \\
\hline
\end{tabular}


Table 2. Boston Complier Characteristics

\begin{tabular}{|c|c|c|c|c|c|c|}
\hline & \multicolumn{2}{|c|}{ O'Bryant } & \multicolumn{2}{|c|}{ Latin Academy } & \multicolumn{2}{|c|}{ Latin School } \\
\hline & $\mathrm{Z}=0$ & $\mathrm{Z}=1$ & $\mathrm{Z}=0$ & $\mathrm{Z}=1$ & $\mathrm{Z}=0$ & $\mathrm{Z}=1$ \\
\hline & $(1)$ & $(2)$ & $(3)$ & $(4)$ & $(5)$ & $(6)$ \\
\hline & \multicolumn{6}{|c|}{ Panel A. 7th Grade Applicants } \\
\hline Baseline Peer Mean in Math & -0.16 & 0.84 & 0.66 & 1.20 & 1.15 & 1.98 \\
\hline Baseline Peer Mean in English & -0.16 & 0.80 & 0.63 & 1.11 & 1.05 & 1.78 \\
\hline Proportion Black or Hispanic & 0.78 & 0.63 & 0.65 & 0.40 & 0.43 & 0.18 \\
\hline Proportion Free Lunch & 0.77 & 0.68 & 0.68 & 0.45 & 0.48 & 0.27 \\
\hline Proportion Female & 0.46 & 0.56 & 0.55 & 0.56 & 0.56 & 0.55 \\
\hline Student/Teacher ratio & 12.2 & 19.7 & 19.6 & 21.2 & 21.3 & 22.0 \\
\hline Teachers licensed to teach assignment & 88.9 & 97.4 & 96.2 & 95.4 & 96.2 & 96.2 \\
\hline Teachers highly qualified in core subject & 90.3 & 92.6 & 93.7 & 95.2 & 95.5 & 95.0 \\
\hline Proportion of teachers 40 and older & 0.42 & 0.63 & 0.65 & 0.51 & 0.54 & 0.53 \\
\hline Proportion of teachers 48 and older & 0.28 & 0.51 & 0.52 & 0.38 & 0.41 & 0.41 \\
\hline \multirow[t]{2}{*}{ Proportion of teachers 56 and older } & 0.10 & 0.27 & 0.28 & 0.19 & 0.20 & 0.21 \\
\hline & \multicolumn{6}{|c|}{ Panel B. 9th Grade Applicants } \\
\hline Baseline Peer Mean in Math & -0.31 & 0.87 & 0.75 & 1.03 & 0.90 & 1.75 \\
\hline Baseline Peer Mean in English & -0.21 & 0.72 & 0.58 & 0.99 & 0.86 & 1.40 \\
\hline Proportion Black or Hispanic & 0.81 & 0.67 & 0.68 & 0.41 & 0.46 & 0.17 \\
\hline Proportion Free Lunch & 0.57 & 0.55 & 0.49 & 0.45 & 0.43 & 0.26 \\
\hline Proportion Female & 0.48 & 0.58 & 0.58 & 0.58 & 0.58 & 0.55 \\
\hline Student/Teacher ratio & 17.7 & 19.9 & 18.6 & 21.2 & 20.8 & 22.1 \\
\hline Proportion of teachers licensed to teach assignment & 0.86 & 0.98 & 0.97 & 0.95 & 0.95 & 0.96 \\
\hline Proportion of teachers highly qualified in core subject & 0.85 & 0.94 & 0.91 & 0.95 & 0.93 & 0.95 \\
\hline Proportion of teachers 40 and older & 0.21 & 0.65 & 0.63 & 0.54 & 0.54 & 0.54 \\
\hline Proportion of teachers 48 and older & 0.17 & 0.52 & 0.51 & 0.40 & 0.41 & 0.42 \\
\hline Proportion of teachers 56 and older & 0.06 & 0.27 & 0.25 & 0.18 & 0.20 & 0.21 \\
\hline
\end{tabular}

Notes: This table shows descriptive statistics for Boston enrollment compliers to the left $(\mathrm{Z}=0)$ and right $(\mathrm{Z}=1)$ of admission cutoffs at the three Boston exam schools. Student-weighted average characteristics of teachers and schools were constructed from data posted at http://profiles.doe.mass.edu/ state_report/teacherdata.aspx. Teachers licensed in teaching assignment describes the percent of teachers who are licensed with Provisional, Initial, or Professional licensure to teach in the subject(s) in which they are posted. Core classes taught by highly qualified teachers is the percent of core academic classes (defined as English, reading or language arts, mathematics, science, foreign languages, civics and government, economics, arts, history, and geography) taught by highly qualified teachers (defined as teachers holding a Massachusetts teaching license and demonstrating subject matter competence in the areas they teach). Teacher data are for Fall 2003-8, except information on core academic teachers, which is for Fall 2003-6 and teacher age, which is for Fall 2007-8. For middle school applicants, peer baseline means are enrollment-weighted scores on 4th grade MCAS for Fall 2000-8. Peer baseline for 9th grade applicants comes from 8th grade MCAS for Fall 2002-8. 
Table 3. Boston Reduced Form Estimates: MCAS Math and English

\begin{tabular}{|c|c|c|c|c|c|c|c|c|c|}
\hline \multirow[b]{2}{*}{$\begin{array}{l}\text { Application } \\
\text { Grade }\end{array}$} & \multirow[b]{2}{*}{$\begin{array}{l}\text { Test } \\
\text { Grade }\end{array}$} & \multicolumn{4}{|c|}{ Parametric Estimates } & \multicolumn{4}{|c|}{ Non-parametric (DM) Estimates } \\
\hline & & $\begin{array}{c}\text { O'Bryant } \\
(1)\end{array}$ & $\begin{array}{c}\text { Latin } \\
\text { Academy } \\
(2) \\
\end{array}$ & $\begin{array}{c}\text { Latin } \\
\text { School } \\
(3) \\
\end{array}$ & $\begin{array}{c}\text { All } \\
\text { Schools } \\
(4) \\
\end{array}$ & $\begin{array}{c}\text { O'Bryant } \\
(5)\end{array}$ & $\begin{array}{c}\text { Latin } \\
\text { Academy } \\
(6) \\
\end{array}$ & $\begin{array}{c}\text { Latin } \\
\text { School } \\
(7)\end{array}$ & $\begin{array}{c}\text { All } \\
\text { Schools } \\
(8) \\
\end{array}$ \\
\hline & \multirow{4}{*}{ 7th and 8th } & \multicolumn{8}{|c|}{ Panel A. Math } \\
\hline \multirow[t]{3}{*}{7 th } & & -0.128 & -0.081 & -0.015 & -0.077 & -0.087 & $-0.143 *$ & -0.001 & $-0.087 * *$ \\
\hline & & $(0.101)$ & $(0.092)$ & $(0.098)$ & $(0.053)$ & $(0.069)$ & $(0.076)$ & $(0.062)$ & $(0.034)$ \\
\hline & & 4035 & 4194 & 3776 & 12005 & 3621 & 3986 & 3066 & 10673 \\
\hline \multirow[t]{3}{*}{7 th and 9 th } & \multirow[t]{3}{*}{10 th } & 0.070 & -0.090 & -0.053 & -0.014 & 0.060 & -0.050 & $-0.076 * *$ & -0.007 \\
\hline & & $(0.070)$ & $(0.080)$ & $(0.055)$ & $(0.038)$ & $(0.046)$ & $(0.044)$ & $(0.033)$ & $(0.027)$ \\
\hline & & 3370 & 2702 & 2457 & 8529 & 3067 & 2022 & 1825 & 6914 \\
\hline \multirow[t]{3}{*}{7 th and 9th } & \multirow[t]{3}{*}{7 th, 8 th, and 10th } & -0.038 & -0.085 & -0.030 & -0.051 & -0.019 & $-0.115 * *$ & -0.029 & $-0.057 * *$ \\
\hline & & $(0.069)$ & $(0.065)$ & $(0.071)$ & $(0.038)$ & $(0.049)$ & $(0.050)$ & $(0.045)$ & $(0.023)$ \\
\hline & & 7405 & 6896 & 6233 & 20534 & 6688 & 6008 & 4891 & 17587 \\
\hline \multirow{4}{*}{7 th } & \multirow{4}{*}{7 th and 8th } & \multicolumn{8}{|c|}{ Panel B. English } \\
\hline & & -0.060 & -0.092 & $-0.183 * * *$ & $-0.109 * *$ & $-0.072 *$ & 0.011 & $-0.136 * * *$ & $-0.069 * * *$ \\
\hline & & $(0.078)$ & $(0.067)$ & $(0.067)$ & $(0.044)$ & $(0.040)$ & $(0.041)$ & $(0.038)$ & $(0.024)$ \\
\hline & & 4139 & 4302 & 3790 & 12231 & 3930 & 3743 & 3524 & 11197 \\
\hline \multirow[t]{3}{*}{7 th and 9 th } & \multirow[t]{3}{*}{10 th } & 0.125 & 0.159 & 0.040 & $0.113 * *$ & $0.152 * * *$ & $0.181 * * *$ & 0.012 & $0.122 * * *$ \\
\hline & & $(0.083)$ & $(0.105)$ & $(0.089)$ & $(0.057)$ & $(0.047)$ & $(0.064)$ & $(0.066)$ & $(0.037)$ \\
\hline & & 3379 & 2707 & 2459 & 8545 & 3289 & 1781 & 1913 & 6983 \\
\hline \multirow[t]{3}{*}{7 th and 9 th } & \multirow[t]{3}{*}{7 th, 8 th, and 10th } & 0.023 & 0.009 & -0.098 & -0.017 & 0.029 & 0.066 & $-0.090 * * *$ & 0.002 \\
\hline & & $(0.056)$ & $(0.073)$ & $(0.064)$ & $(0.041)$ & $(0.033)$ & $(0.042)$ & $(0.033)$ & $(0.023)$ \\
\hline & & 7518 & 7009 & 6249 & 20776 & 7219 & 5524 & 5437 & 18180 \\
\hline
\end{tabular}

Notes: This table reports estimates of the effects of exam school offers on MCAS scores. The sample covers students within 20 standardized units of offer cutoffs. Parametric models include a cubic function of the running variable, allowed to differ on either side of offer cutoffs. Non-parametric estimates use the edge kernel, with bandwidth computed following DesJardins \& McCall (2008) and Imbens and Kalyanaram (2012), as described in the text. Optimal bandwidths were computed separately for each school. Robust standard errors, clustered on year and school, are shown in parentheses. Standard errors for the all-school estimates and for those pooling outcomes also cluster on student. The sample size is reported below standard errors.

$*$ significant at $10 \% ; * *$ significant at $5 \% ; * * *$ significant at $1 \%$ 
Table 4. Boston Reduced Form Estimates for High Achievers

\begin{tabular}{|c|c|c|c|c|c|c|}
\hline \multirow[b]{3}{*}{$\begin{array}{l}\text { Application } \\
\text { Grade }\end{array}$} & \multirow[b]{3}{*}{$\begin{array}{l}\text { Test } \\
\text { Grade }\end{array}$} & \multirow[b]{3}{*}{$\begin{array}{c}\text { Baseline mean for } \\
\text { enrolled } \\
\text { (1) }\end{array}$} & \multicolumn{4}{|c|}{ Conditional on Baseline Score } \\
\hline & & & \multicolumn{2}{|c|}{ Baseline in Upper Half } & \multicolumn{2}{|c|}{ Baseline in Upper Quartile } \\
\hline & & & $\begin{array}{l}\text { Baseline mean } \\
\text { (2) }\end{array}$ & $\begin{array}{c}\text { Estimate } \\
(3)\end{array}$ & $\begin{array}{c}\text { Baseline mean } \\
(4)\end{array}$ & $\begin{array}{c}\text { Estimate } \\
(5)\end{array}$ \\
\hline & & & \multicolumn{4}{|c|}{ A. Math } \\
\hline \multirow[t]{2}{*}{7 th } & 7th and 8th & 1.436 & 1.534 & $\begin{array}{c}-0.110^{* * *} \\
(0.041)\end{array}$ & 2.128 & $\begin{array}{l}-0.036 \\
(0.063)\end{array}$ \\
\hline & & 4044 & 5255 & 5968 & 2620 & 2896 \\
\hline \multirow[t]{2}{*}{ 7th and 9th } & 10th & 1.361 & 1.377 & $\begin{array}{l}-0.020 \\
(0.024)\end{array}$ & 1.853 & $\begin{array}{c}0.003 \\
(0.031)\end{array}$ \\
\hline & & 3747 & 4626 & 4187 & 2607 & 2452 \\
\hline \multirow[t]{3}{*}{ 7th and 9th } & 7th, 8th, and 10th & 1.357 & 1.461 & $\begin{array}{c}-0.075^{* * *} \\
(0.027)\end{array}$ & 1.991 & $\begin{array}{l}-0.018 \\
(0.038)\end{array}$ \\
\hline & & 5115 & 9881 & 10155 & 5227 & 5348 \\
\hline & & & \multicolumn{4}{|c|}{ B. English } \\
\hline \multirow[t]{2}{*}{7 th } & 7th and 8th & 1.315 & 1.419 & $\begin{array}{c}-0.079 * * * \\
(0.029)\end{array}$ & 1.847 & $\begin{array}{c}-0.102 * * \\
(0.042)\end{array}$ \\
\hline & & 4030 & 5840 & 6910 & 2971 & 3032 \\
\hline \multirow[t]{2}{*}{ 7th and 9th } & 10th & 1.208 & 1.249 & $\begin{array}{c}0.059 \\
(0.038)\end{array}$ & 1.575 & $\begin{array}{c}0.099 * * \\
(0.047)\end{array}$ \\
\hline & & 3465 & 4345 & 4377 & 2474 & 2460 \\
\hline \multirow[t]{2}{*}{ 7th and 9th } & 7th, 8th, and 10th & 1.234 & 1.346 & $\begin{array}{l}-0.026 \\
(0.027)\end{array}$ & 1.723 & $\begin{array}{l}-0.010 \\
(0.037)\end{array}$ \\
\hline & & 4830 & 10185 & 11287 & 5445 & 5492 \\
\hline
\end{tabular}

Notes: This table reports reduced form estimates for Boston exam school applicants with high baseline MCAS scores. The baseline mean reported in column 1 is the average baseline MCAS score for applicants who enroll in an exam school, conditional on inclusion in at least one school's discontinuity sample. Conditional-on-baseline estimates are non-parametric estimates in upper-half and upper-quartile subsamples, with bandwidth computed as for the all-schools results reported in Table 4.

$*$ significant at $10 \% ; * *$ significant at $5 \% ; * * *$ significant at $1 \%$ 
Table 5. Boston Reduced Form Estimates: PSAT, SAT, and AP Scores

\begin{tabular}{|c|c|c|c|c|c|c|c|c|}
\hline $\begin{array}{l}\text { Application } \\
\text { Grade }\end{array}$ & $\begin{array}{c}\text { O'Bryant } \\
\text { (1) }\end{array}$ & $\begin{array}{c}\text { Latin } \\
\text { Academy } \\
(2) \\
\end{array}$ & $\begin{array}{c}\text { Latin } \\
\text { School } \\
(3)\end{array}$ & $\begin{array}{c}\text { All } \\
\text { Schools } \\
(4)\end{array}$ & $\begin{array}{c}\text { O'Bryant } \\
(5)\end{array}$ & $\begin{array}{c}\text { Latin } \\
\text { Academy } \\
(6) \\
\end{array}$ & $\begin{array}{c}\text { Latin } \\
\text { School } \\
(7)\end{array}$ & $\begin{array}{c}\text { All } \\
\text { Schools } \\
(8)\end{array}$ \\
\hline & \multicolumn{4}{|c|}{ Probability Tested } & \multicolumn{4}{|c|}{ Test Score for Takers } \\
\hline & & & & $P a r$ & $S A T$ & & & \\
\hline \multirow[t]{4}{*}{ 7th and 9th } & $0.062 * *$ & 0.003 & $-0.065 *$ & 0.010 & 0.037 & -0.011 & 0.032 & 0.024 \\
\hline & $(0.026)$ & $(0.023)$ & $(0.037)$ & $(0.017)$ & $(0.042)$ & $(0.055)$ & $(0.061)$ & $(0.030)$ \\
\hline & 2683 & 2053 & 1795 & 6531 & 2670 & 1433 & 1351 & 5454 \\
\hline & \multicolumn{8}{|c|}{ Panel B. SAT } \\
\hline \multirow[t]{5}{*}{7 th and 9th } & -0.008 & 0.017 & 0.012 & 0.004 & 0.045 & -0.019 & 0.089 & 0.042 \\
\hline & $(0.032)$ & $(0.028)$ & $(0.024)$ & $(0.018)$ & $(0.041)$ & $(0.050)$ & $(0.065)$ & $(0.033)$ \\
\hline & 2410 & 1683 & 1541 & 5634 & 2343 & 1425 & 1516 & 5284 \\
\hline & \multicolumn{4}{|c|}{ Number of Exams } & \multicolumn{4}{|c|}{ Sum of Scores } \\
\hline & & & & Panel C & ll Exams & & & \\
\hline \multirow[t]{4}{*}{ 7th and 9th } & 0.094 & -0.164 & 0.106 & 0.029 & $0.780 * * *$ & -0.542 & 0.105 & 0.271 \\
\hline & $(0.124)$ & $(0.216)$ & $(0.164)$ & $(0.063)$ & $(0.281)$ & $(0.609)$ & $(0.539)$ & $(0.188)$ \\
\hline & 2543 & 1688 & 1822 & 6053 & 2540 & 1599 & 1405 & 5544 \\
\hline & \multicolumn{8}{|c|}{ Panel D. AP - Exams with 500+ Takers } \\
\hline \multirow[t]{3}{*}{ 7th and 9th } & -0.014 & -0.196 & -0.196 & $-0.115^{*}$ & $0.416^{*}$ & -0.670 & -0.399 & -0.077 \\
\hline & $(0.111)$ & $(0.191)$ & $(0.126)$ & $(0.062)$ & $(0.233)$ & $(0.540)$ & $(0.434)$ & $(0.163)$ \\
\hline & 2567 & 1674 & 1984 & 6225 & 2517 & 1583 & 1530 & 5630 \\
\hline
\end{tabular}

estimates of effects of exam school offers on PSAT, SAT, and AP test taking and scores. Each panel shows estimates for pooled B/C, English Language and Composition, English Literature and Composition, European History, US Government and Politics, US History,

Microeconomics, and Macroeconomics). Outcome-specific non-parametric estimates, bandwidths, and standard errors were computed as for Table 3.

* significant at $10 \%$;* significant at $5 \% ; * * *$ significant at $1 \%$ 
Table 6. Boston Reduced Form Estimates: Post-Secondary Outcomes

\begin{tabular}{|c|c|c|c|c|c|c|c|c|}
\hline \multirow{3}{*}{$\begin{array}{l}\text { Application } \\
\text { Grade }\end{array}$} & \multicolumn{4}{|c|}{ Parametric Estimates } & \multicolumn{4}{|c|}{ Non-parametric (DM) Estimates } \\
\hline & O'Bryant & $\begin{array}{c}\text { Latin } \\
\text { Academy }\end{array}$ & $\begin{array}{c}\text { Latin } \\
\text { School } \\
\end{array}$ & $\begin{array}{c}\text { All } \\
\text { Schools }\end{array}$ & O'Bryant & $\begin{array}{c}\text { Latin } \\
\text { Academy }\end{array}$ & $\begin{array}{c}\text { Latin } \\
\text { School } \\
\end{array}$ & $\begin{array}{c}\text { All } \\
\text { Schools } \\
\end{array}$ \\
\hline & $(1)$ & $(2)$ & $(3)$ & $(4)$ & $(5)$ & (6) & $(7)$ & $(8)$ \\
\hline \multirow{4}{*}{ 7th and 9th } & \multicolumn{8}{|c|}{ Panel A. Attended Any College } \\
\hline & -0.028 & 0.058 & 0.050 & 0.020 & 0.005 & $0.057 *$ & 0.057 & $0.033 *$ \\
\hline & $(0.053)$ & $(0.064)$ & $(0.056)$ & $(0.030)$ & $(0.030)$ & $(0.032)$ & $(0.035)$ & $(0.018)$ \\
\hline & 2678 & 2159 & 2030 & 6867 & 2608 & 1876 & 1279 & 5763 \\
\hline \multirow{4}{*}{ 7th and 9th } & \multicolumn{8}{|c|}{ Panel B. Attended 4-Year College } \\
\hline & -0.079 & 0.019 & $0.109 *$ & 0.003 & -0.049 & 0.050 & $0.091 * *$ & 0.013 \\
\hline & $(0.070)$ & $(0.078)$ & $(0.064)$ & $(0.038)$ & $(0.043)$ & $(0.035)$ & $(0.037)$ & $(0.025)$ \\
\hline & 2678 & 2159 & 2030 & 6867 & 2654 & 2077 & 1403 & 6134 \\
\hline \multirow{4}{*}{7 th and 9th } & \multicolumn{8}{|c|}{ Panel C. Attended Competitive College } \\
\hline & -0.110 & 0.011 & 0.110 & -0.012 & $-0.105 * *$ & 0.045 & $0.085 *$ & -0.012 \\
\hline & $(0.080)$ & $(0.090)$ & $(0.083)$ & $(0.050)$ & $(0.048)$ & $(0.046)$ & $(0.047)$ & $(0.029)$ \\
\hline & 2678 & 2159 & 2030 & 6867 & 2522 & 2159 & 1304 & 5985 \\
\hline \multirow{4}{*}{7 th and 9th } & \multicolumn{8}{|c|}{ Panel D. Attended Highly Competitive College } \\
\hline & -0.074 & 0.049 & 0.025 & -0.009 & $-0.069 * * *$ & 0.044 & -0.025 & -0.023 \\
\hline & $(0.049)$ & $(0.054)$ & $(0.083)$ & $(0.031)$ & $(0.023)$ & $(0.032)$ & $(0.048)$ & $(0.017)$ \\
\hline & 2678 & 2159 & 2030 & 6867 & 2640 & 2005 & 1490 & 6135 \\
\hline
\end{tabular}

Notes: This table reports estimates of the effects of exam school offers on college enrollment using data from the National Student

Clearinghouse. College selectivity is as classified by Barron's. Each panel shows estimates for pooled 7th and 9th grade applicants.

Outcome-specific non-parametric estimates, bandwidths, and standard errors were computed as for Table 3.

$*$ significant at $10 \% ; * *$ significant at $5 \% ; * * *$ significant at $1 \%$ 
Table 7. NYC Complier Characteristics

\begin{tabular}{|c|c|c|c|c|c|c|}
\hline & \multicolumn{2}{|c|}{ Brooklyn Tech } & \multicolumn{2}{|c|}{ Bronx Science } & \multicolumn{2}{|c|}{ Stuyvesant } \\
\hline & $\mathrm{Z}=0$ & $\mathrm{Z}=1$ & $\mathrm{Z}=0$ & $\mathrm{Z}=1$ & $\mathrm{Z}=0$ & $\mathrm{Z}=1$ \\
\hline & $(1)$ & $(2)$ & $(3)$ & $(4)$ & $(5)$ & $(6)$ \\
\hline Baseline Peer Mean in Math & 0.35 & 1.60 & 1.21 & 1.75 & 1.58 & 2.12 \\
\hline Baseline Peer Mean in English & 0.31 & 1.44 & 1.21 & 1.69 & 1.51 & 2.08 \\
\hline Proportion Black or Hispanic & 0.57 & 0.23 & 0.39 & 0.12 & 0.20 & 0.05 \\
\hline Proportion Free Lunch & 0.65 & 0.61 & 0.60 & 0.65 & 0.64 & 0.68 \\
\hline Proportion Female & 0.53 & 0.41 & 0.52 & 0.45 & 0.46 & 0.43 \\
\hline Average English class size & 29.3 & 31.8 & 27.1 & 31.8 & 31.0 & 29.1 \\
\hline Average Math class size & 29.0 & 31.1 & 27.8 & 31.6 & 30.9 & 33.0 \\
\hline Proportion of teachers fully licensed & 0.96 & 0.97 & 0.97 & 0.97 & 0.97 & 0.99 \\
\hline Proportion of teachers highly educated & 0.45 & 0.59 & 0.51 & 0.60 & 0.60 & 0.64 \\
\hline Proportion of teachers with less than 3 years experience & 0.13 & 0.07 & 0.12 & 0.12 & 0.10 & 0.07 \\
\hline
\end{tabular}


Table 8. NYC Reduced Form Estimates: Regents Exams

\begin{tabular}{|c|c|c|c|c|c|c|c|c|}
\hline & \multicolumn{4}{|c|}{ Parametric Estimates } & \multicolumn{4}{|c|}{ Non-parametric (DM) Estimates } \\
\hline & $\begin{array}{c}\text { Brooklyn Tech } \\
\text { (1) }\end{array}$ & $\begin{array}{c}\text { Bronx Science } \\
\text { (2) }\end{array}$ & $\begin{array}{c}\text { Stuyvesant } \\
\text { (3) }\end{array}$ & $\begin{array}{c}\text { All Schools } \\
\text { (4) }\end{array}$ & $\begin{array}{c}\text { Brooklyn Tech } \\
\text { (5) }\end{array}$ & $\begin{array}{c}\text { Bronx Science } \\
\text { (6) }\end{array}$ & $\begin{array}{c}\text { Stuyvesant } \\
\text { (7) }\end{array}$ & $\begin{array}{c}\text { All Schools } \\
\text { (8) }\end{array}$ \\
\hline \multirow[t]{3}{*}{ Math } & 0.048 & $-0.105^{*}$ & -0.05 & -0.032 & 0.01 & $-0.132 * * *$ & -0.045 & $-0.062 * * *$ \\
\hline & $(0.060)$ & $(0.054)$ & $(0.044)$ & $(0.027)$ & $(0.039)$ & $(0.033)$ & $(0.039)$ & $(0.018)$ \\
\hline & 5116 & 4479 & 4259 & 13854 & 3990 & 4479 & 2915 & 11384 \\
\hline \multirow[t]{3}{*}{ Advanced Math } & -0.081 & -0.04 & -0.023 & -0.046 & -0.013 & -0.053 & -0.026 & -0.034 \\
\hline & $(0.072)$ & $(0.062)$ & $(0.040)$ & $(0.038)$ & $(0.047)$ & $(0.040)$ & $(0.026)$ & $(0.024)$ \\
\hline & 6758 & 6605 & 7308 & 20671 & 4859 & 6605 & 5350 & 16814 \\
\hline \multirow[t]{3}{*}{ English } & 0.03 & -0.042 & -0.02 & -0.011 & 0.048 & -0.011 & -0.005 & 0.012 \\
\hline & $(0.051)$ & $(0.038)$ & $(0.033)$ & $(0.025)$ & $(0.038)$ & $(0.021)$ & $(0.022)$ & $(0.013)$ \\
\hline & 5926 & 5506 & 5693 & 17125 & 5926 & 5506 & 5693 & 17125 \\
\hline \multirow[t]{3}{*}{ Global History } & $-0.112^{* *}$ & -0.039 & -0.008 & $-0.051 * *$ & $-0.060 *$ & -0.013 & 0.014 & -0.02 \\
\hline & $(0.048)$ & $(0.036)$ & $(0.036)$ & $(0.023)$ & $(0.031)$ & $(0.027)$ & $(0.024)$ & $(0.014)$ \\
\hline & 7540 & 7103 & 7635 & 22278 & 6920 & 7103 & 5918 & 19941 \\
\hline \multirow[t]{3}{*}{ US History } & $-0.100^{* * *}$ & -0.012 & 0.032 & -0.024 & -0.036 & -0.015 & 0.038 & -0.006 \\
\hline & $(0.037)$ & $(0.030)$ & $(0.032)$ & $(0.023)$ & $(0.022)$ & $(0.021)$ & $(0.023)$ & $(0.014)$ \\
\hline & 5316 & 5139 & 5486 & 15941 & 3886 & 5139 & 3913 & 12938 \\
\hline \multirow[t]{3}{*}{ Living Environment } & $-0.077 * *$ & $0.069 *$ & $-0.061 *$ & -0.024 & $-0.078 * * *$ & $0.057 * *$ & -0.032 & $-0.024 * *$ \\
\hline & $(0.038)$ & $(0.037)$ & $(0.034)$ & $(0.020)$ & $(0.022)$ & $(0.024)$ & $(0.020)$ & $(0.012)$ \\
\hline & 6980 & 6575 & 6991 & 20546 & 6980 & 5665 & 6991 & 19636 \\
\hline
\end{tabular}

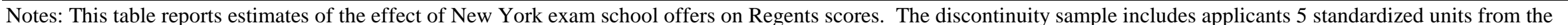
cutoff. Model parameterization and estimation procedures are the same as for Boston. Math scores are from Regents Math A (Elementary Algebra and Planar Geometry) or

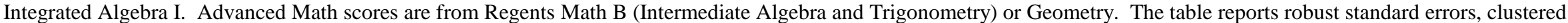
on year and school of test, in parentheses. Standard errors are also clustered on student when schools are stacked. Sample sizes for each outcome are reported below the standard errors.

*significant at $10 \%$; **ignificant at $5 \%$; ***significant at $1 \%$. 
Table 9. 2SLS Estimates for Boston and New York

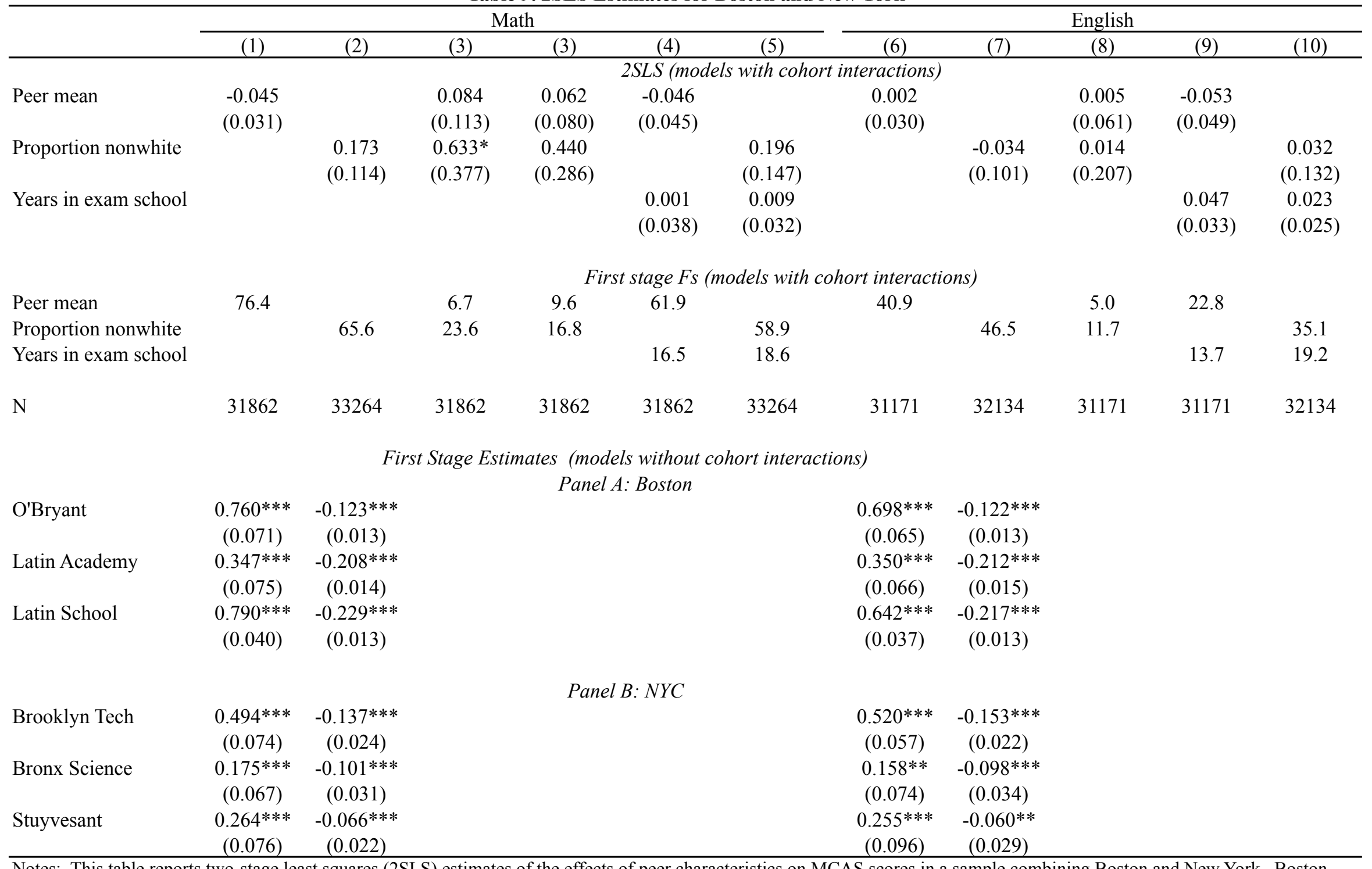

Notes: This table reports two-stage least squares (2SLS) estimates of the effects of peer characteristics on MCAS scores in a sample combining Boston and New York. Boston scores are from MCAS Math and English tests for all grades tested; NYC scores are Advanced Math (Regents Math B or Geometry) and Regents English. The table shows nonparametric estimates using bandwidths computed one school at a time. The 2SLS estimates and first-stage Fs reported here are from models that interact exam school offers with application cohort dummies. The first-stage coefficient estimates are from models without these interactions.

* significant at $10 \% ; *$ significant at $5 \% ; * *$ significant at $1 \%$ 


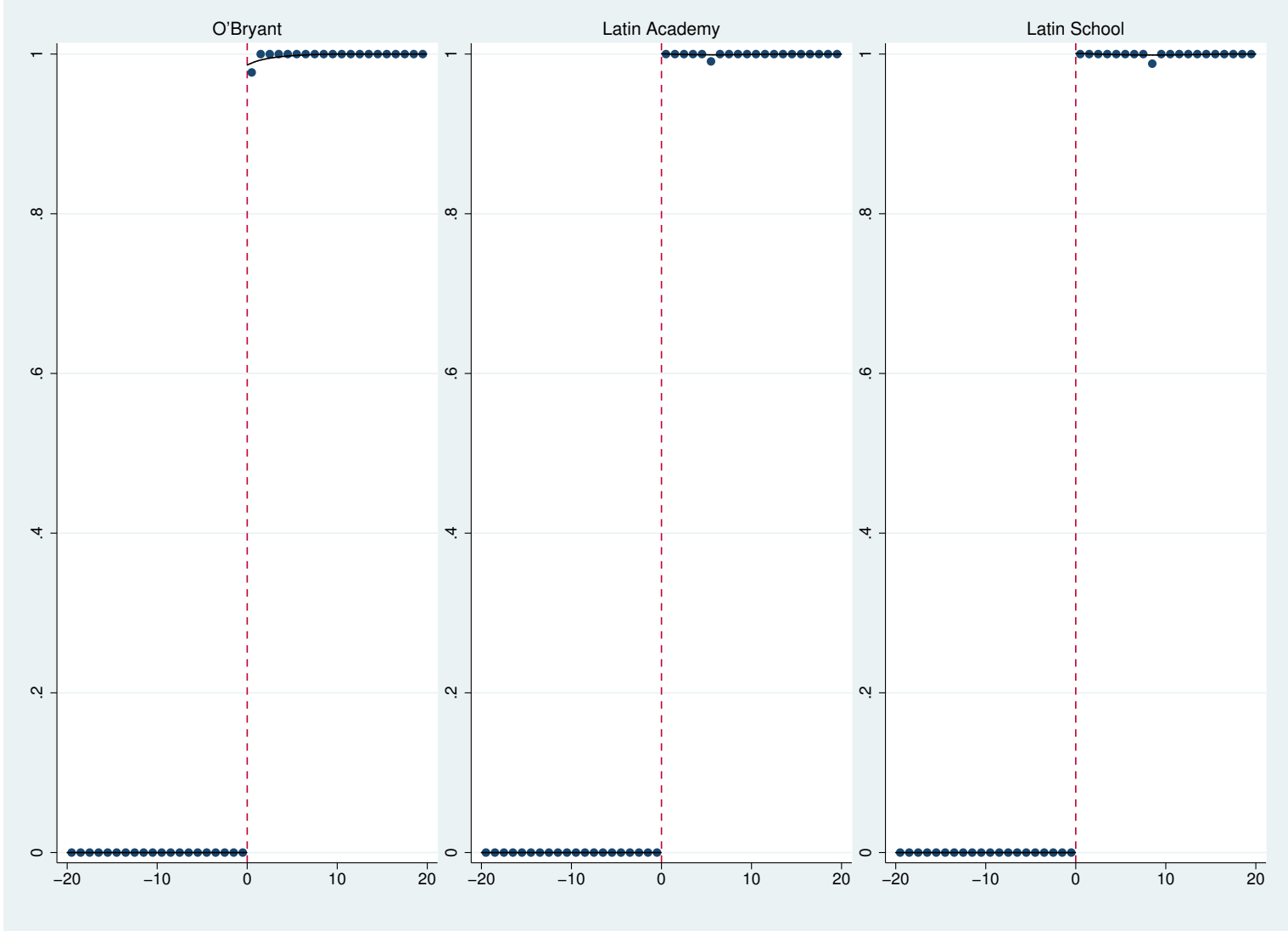

Figure 1A: Offers at Each Boston Exam School

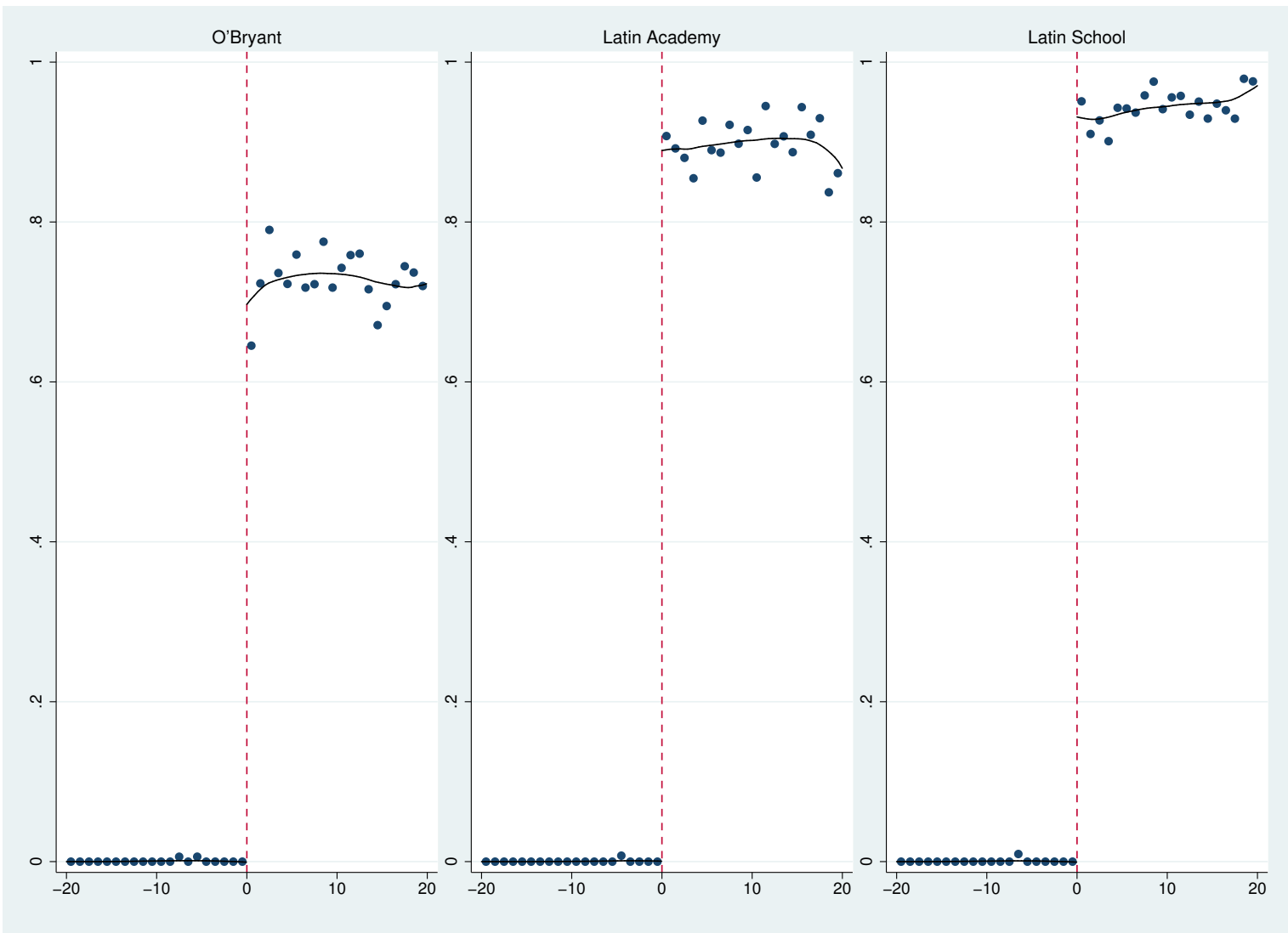

Figure 1B: Enrollment at Each Boston Exam School 


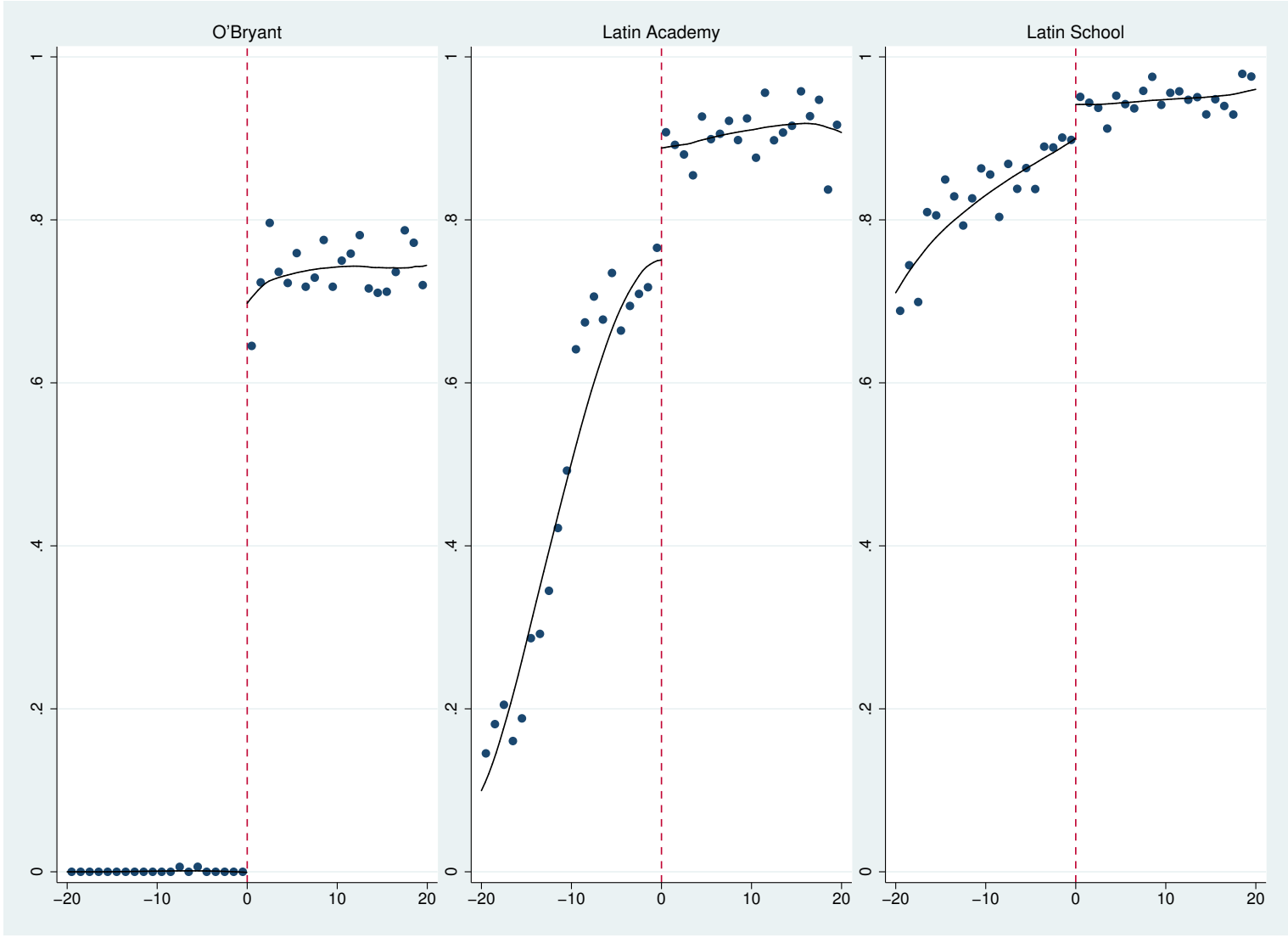

Figure 1C: Enrollment at Any Boston Exam School

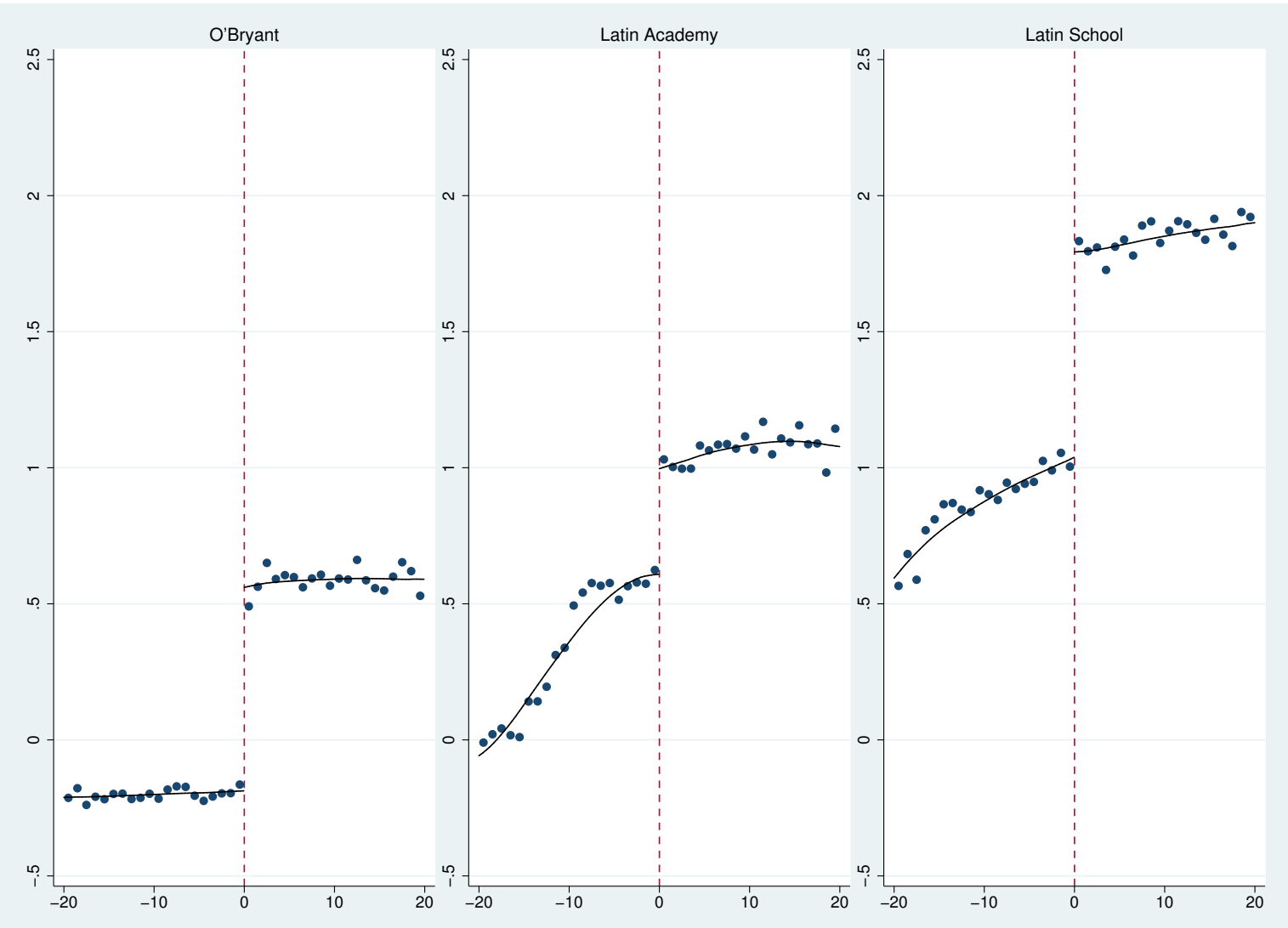

Figure 2A: Baseline Peer Math Score at Boston Exam Schools 


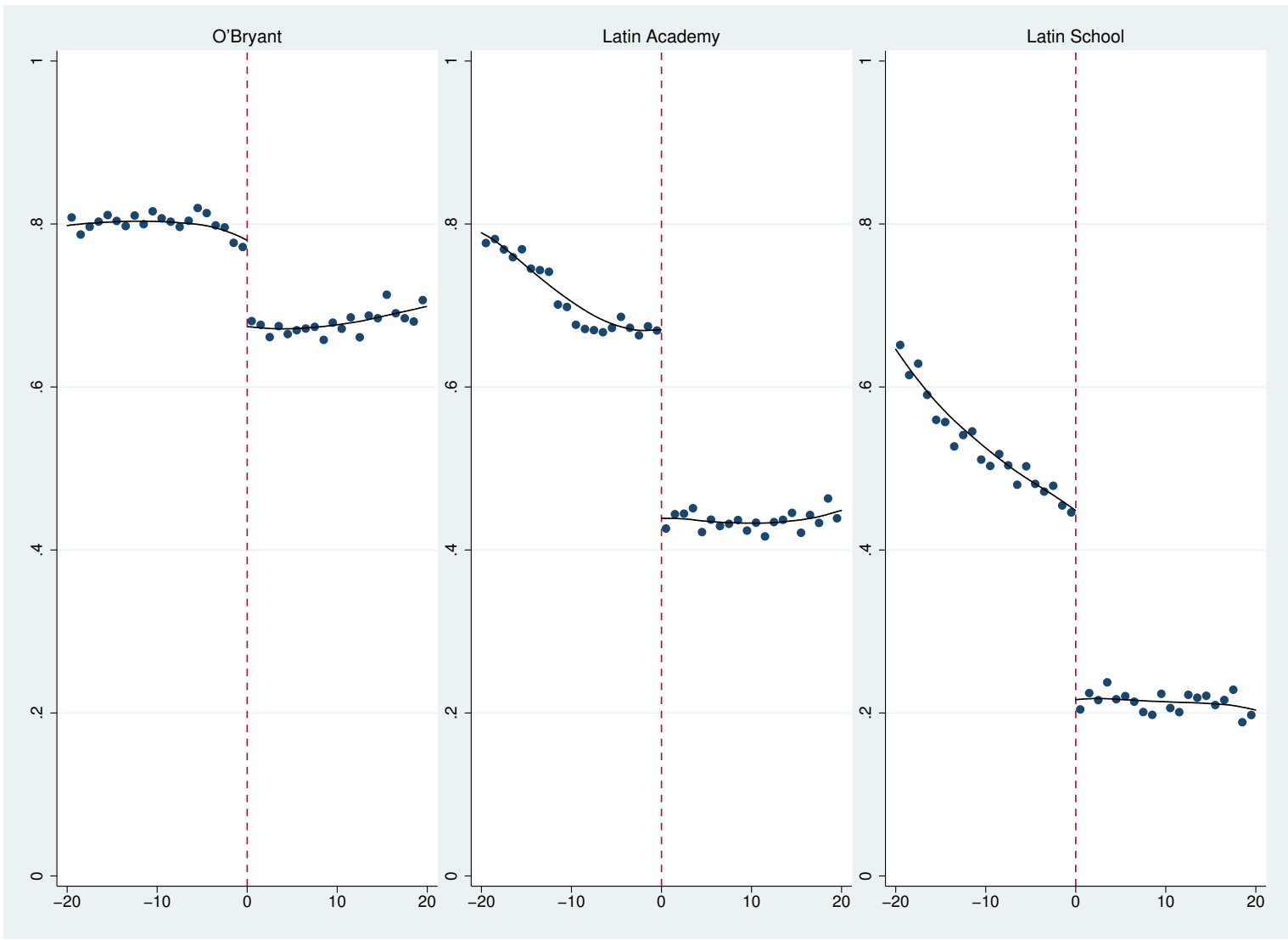

Figure 2B: Proportion Black or Hispanic at Boston Exam Schools

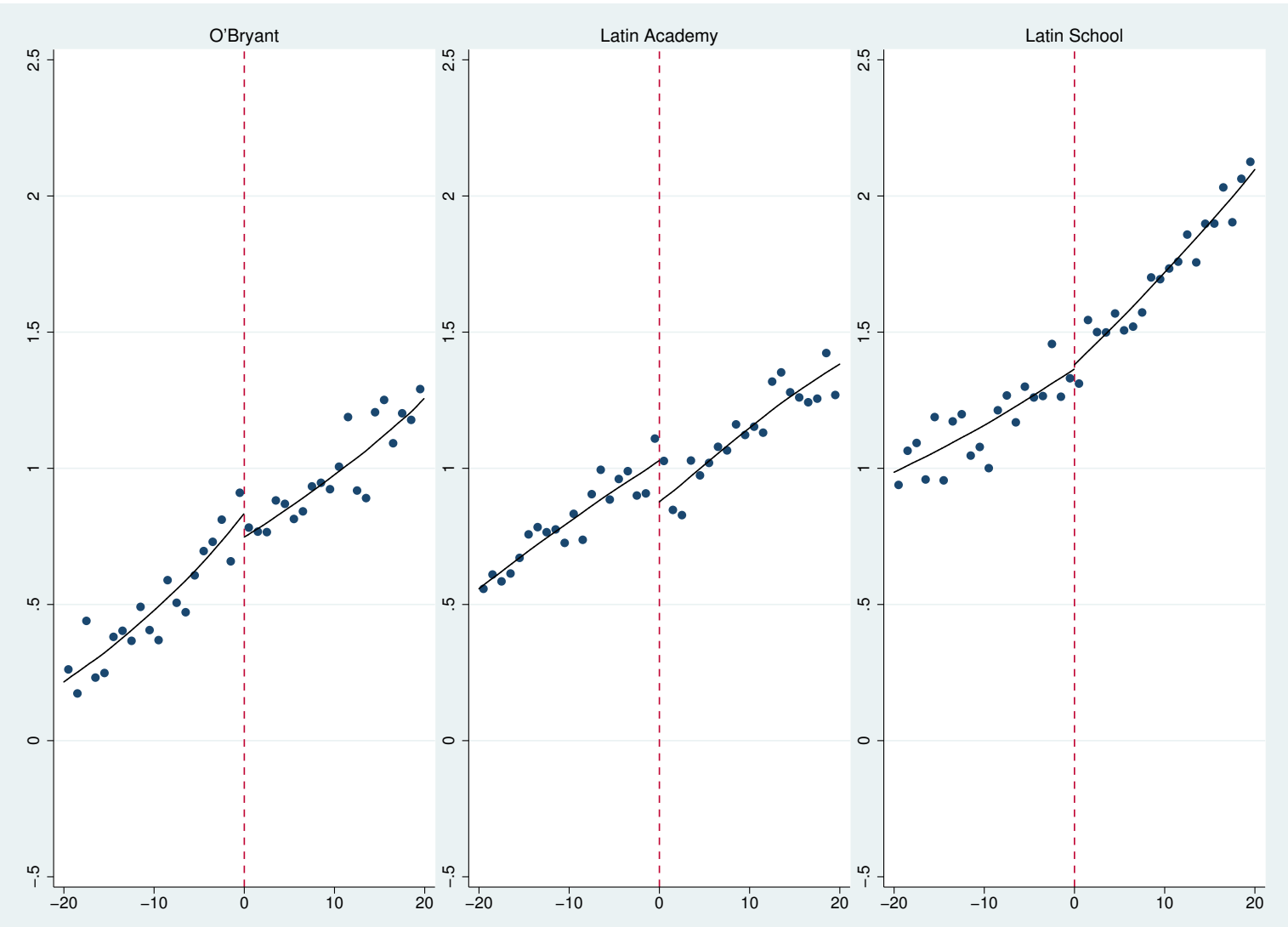

Figure 3A: 7th and 8th Grade Math at Boston Exam Schools for 7th Grade Applicants 


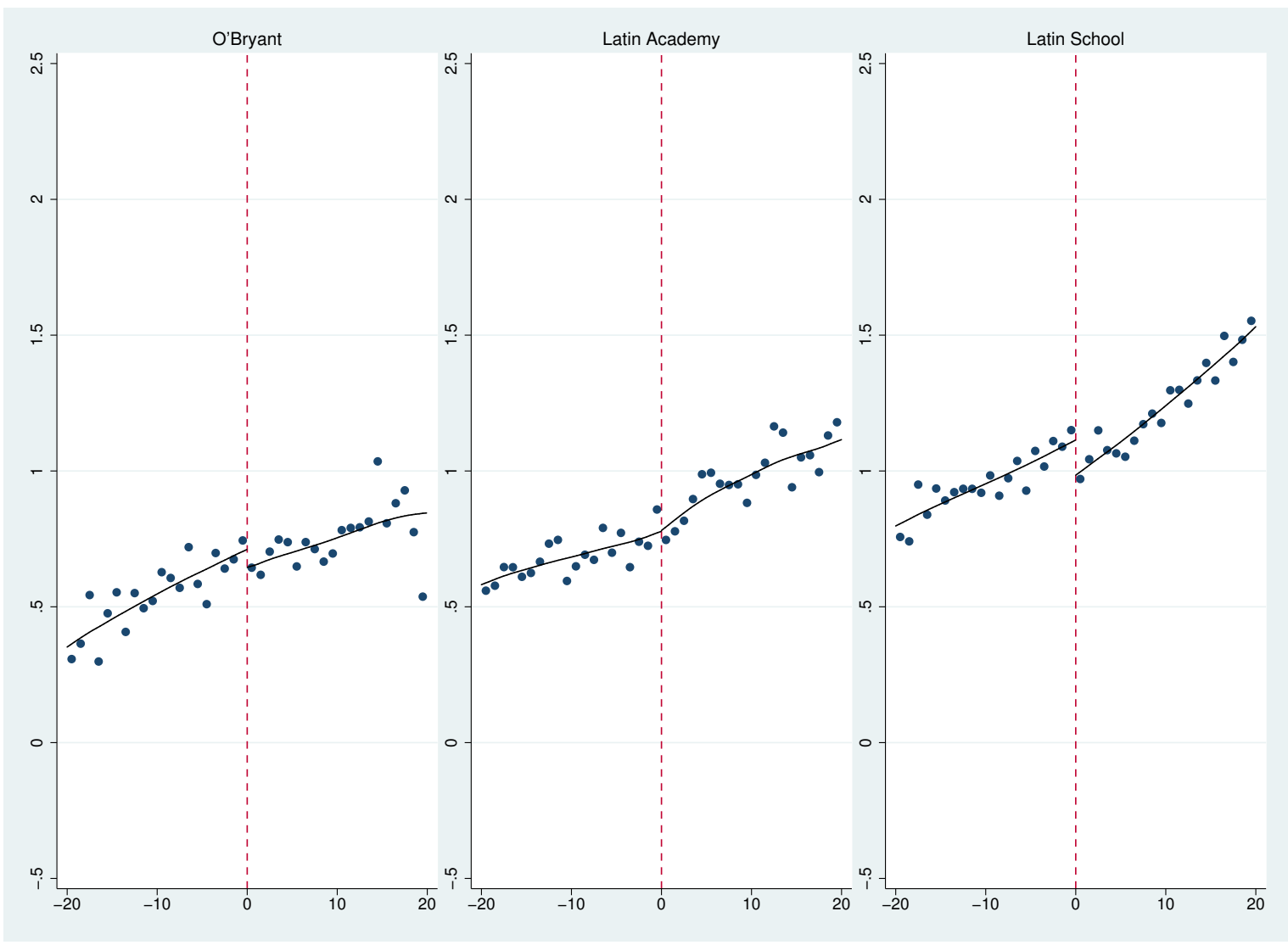

Figure 3B: 7th and 8th Grade English at Boston Exam Schools for 7th Grade Applicants

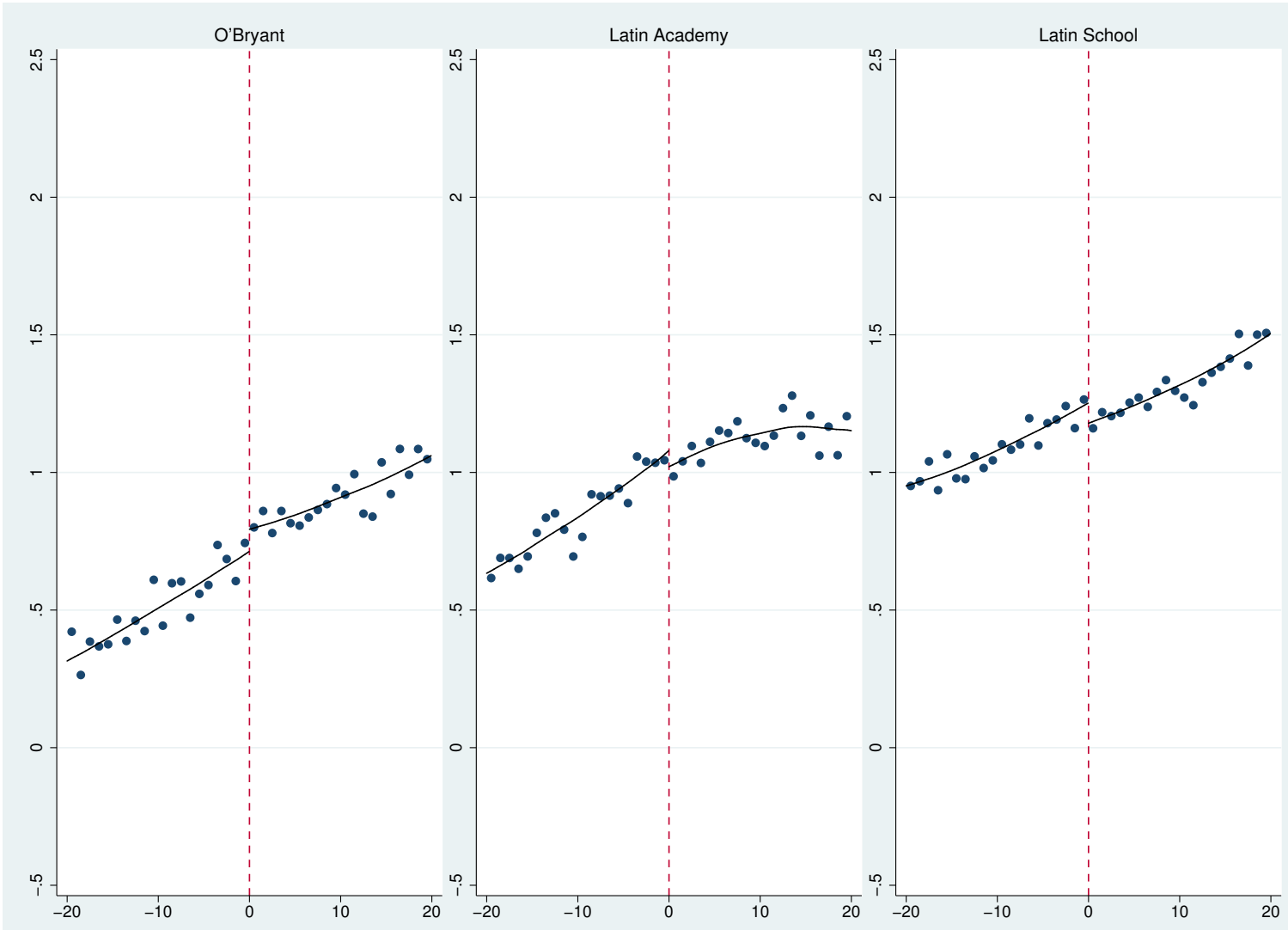

Figure 4A: 10th Grade Math at Boston Exam Schools for 7th and 9th Grade Applicants 


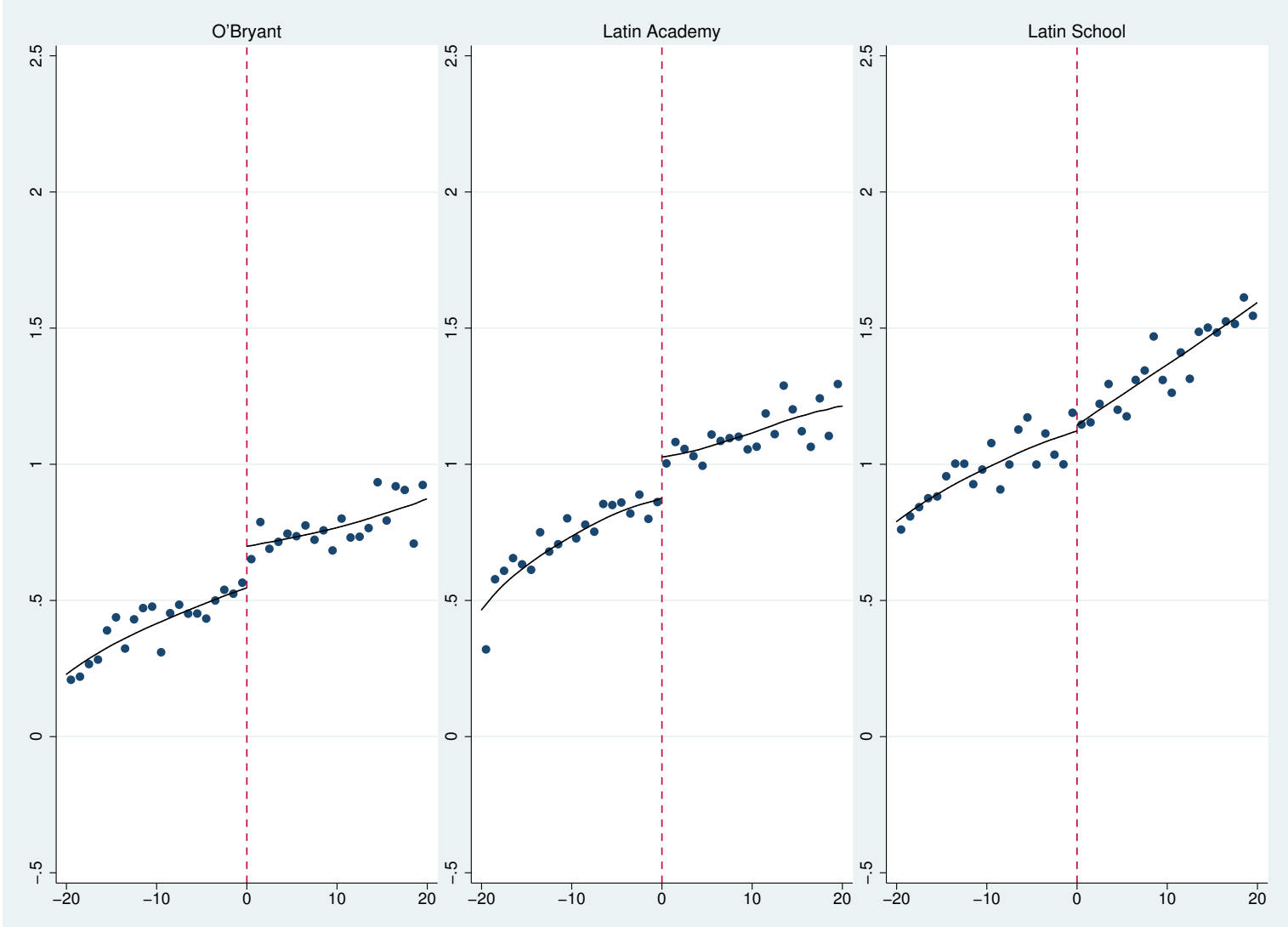

Figure 4B: 10th Grade English at Boston Exam Schools for 7th and 9th Grade Applicants 


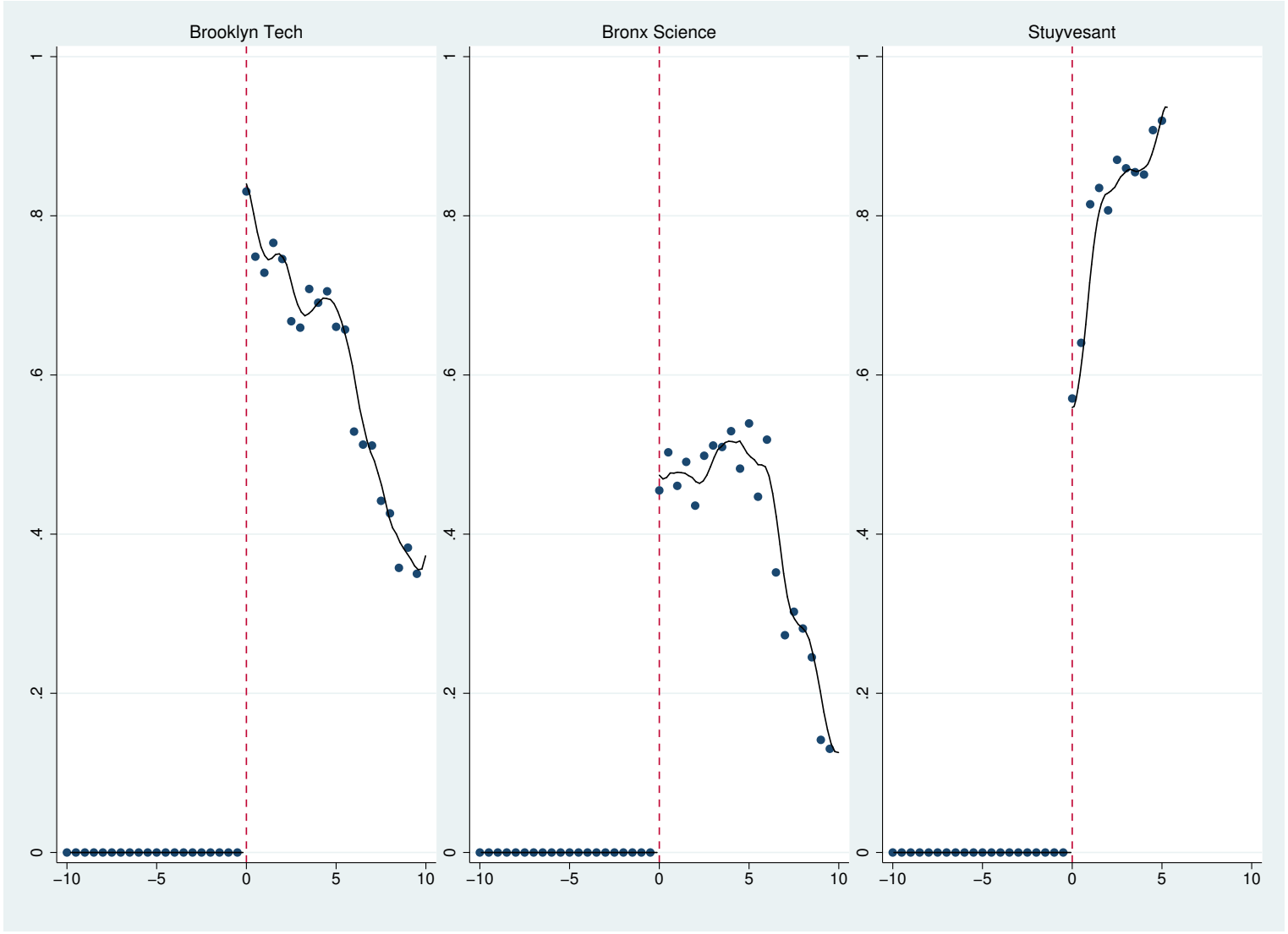

Figure 5A: Offers at Each NYC Exam Schools

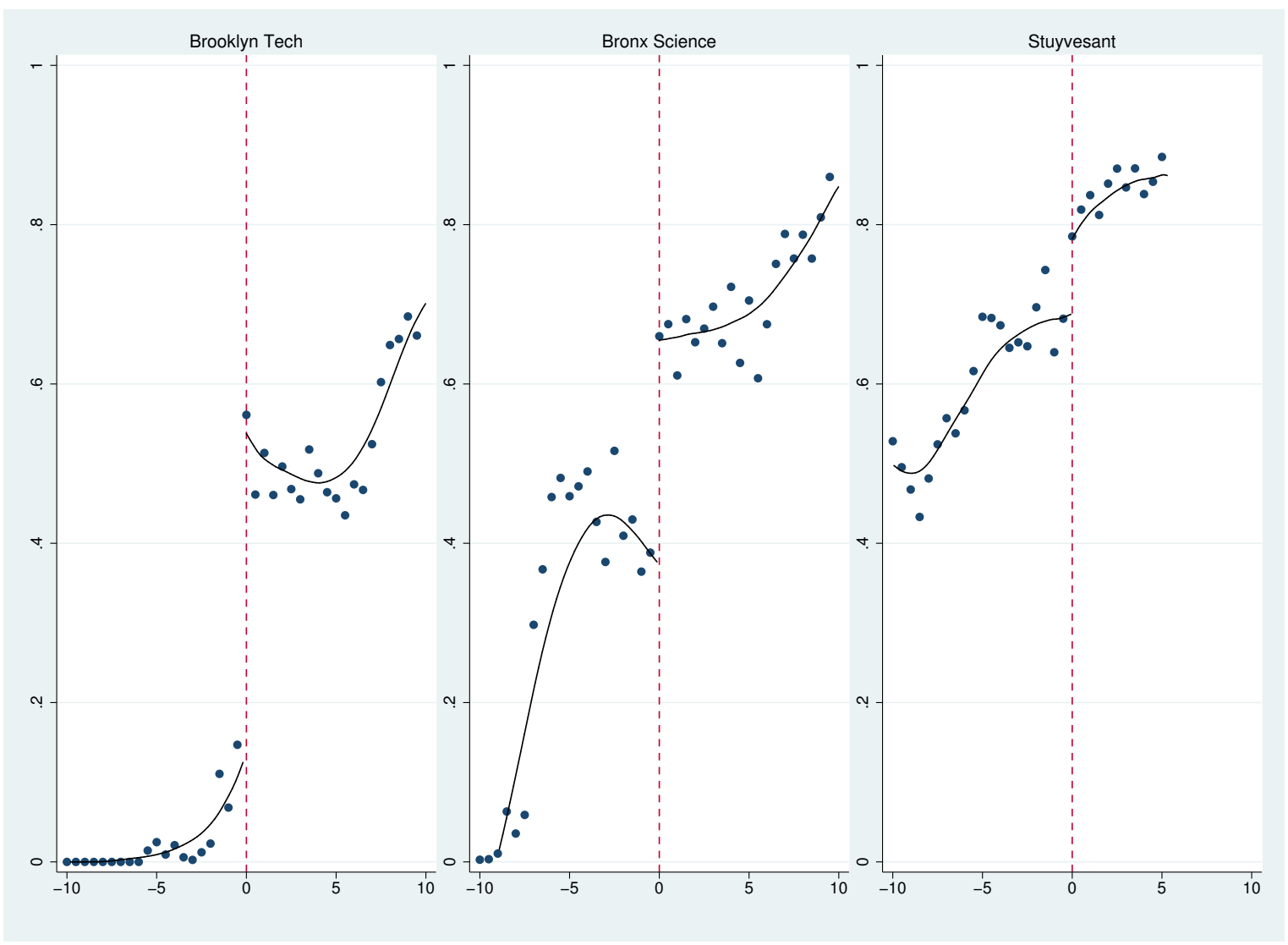

Figure 5B: Enrollment at Any NYC Exam School 


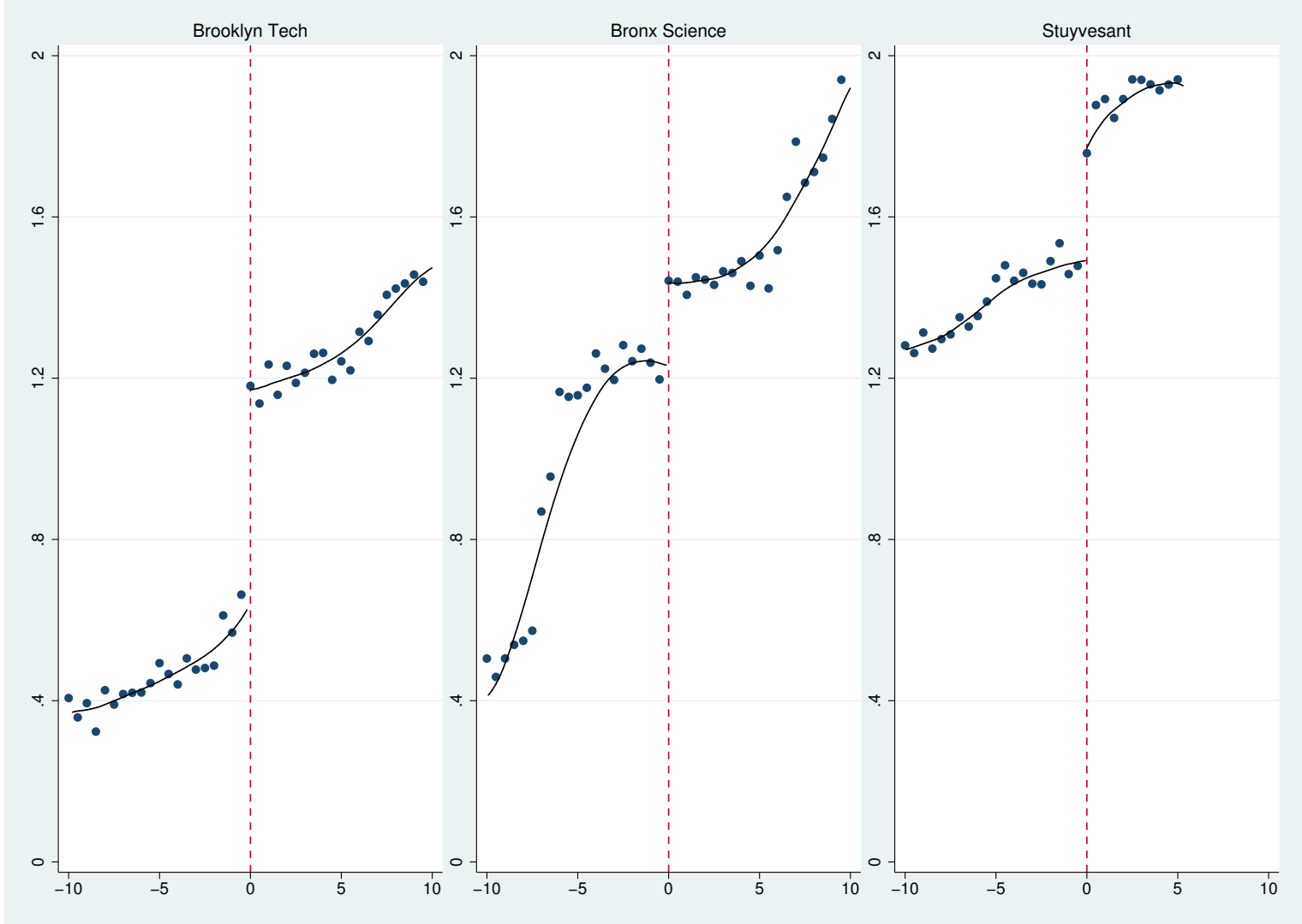

Figure 6A: Baseline Peer Math Score at NYC Exam Schools

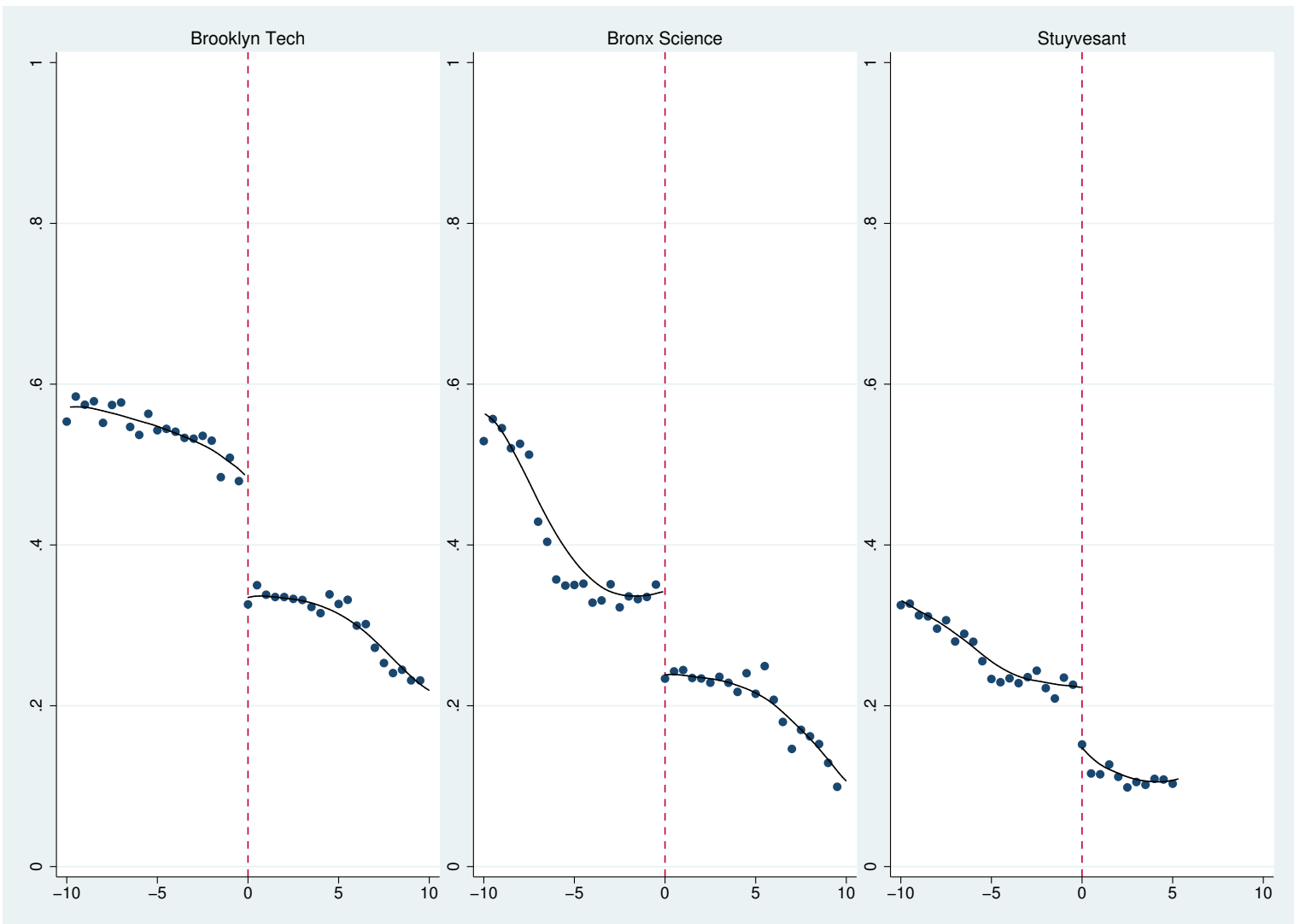

Figure 6B: Proportion Black or Hispanic at NYC Exam Schools 


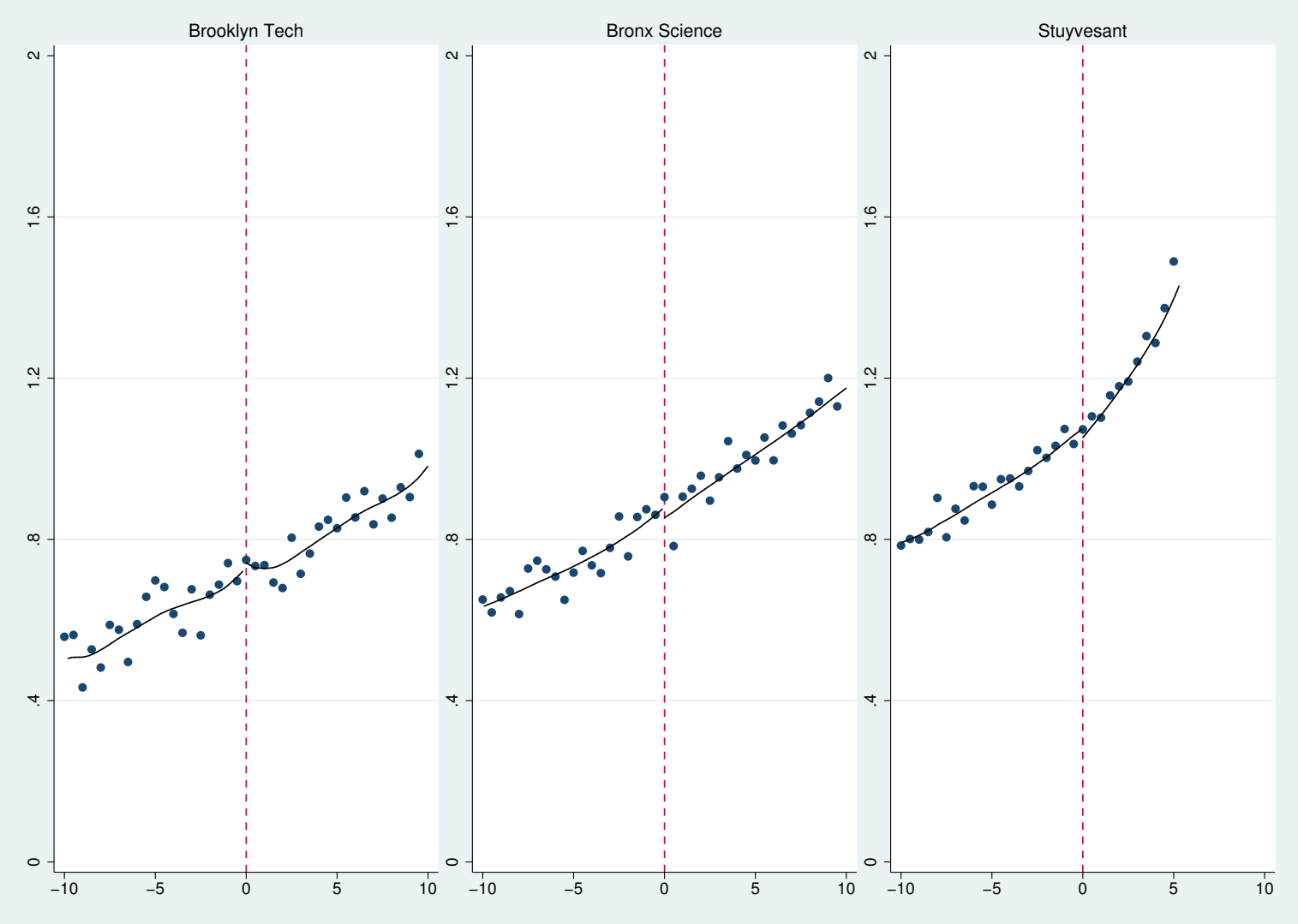

Figure 7A: Regents Advanced Math at NYC Exam Schools

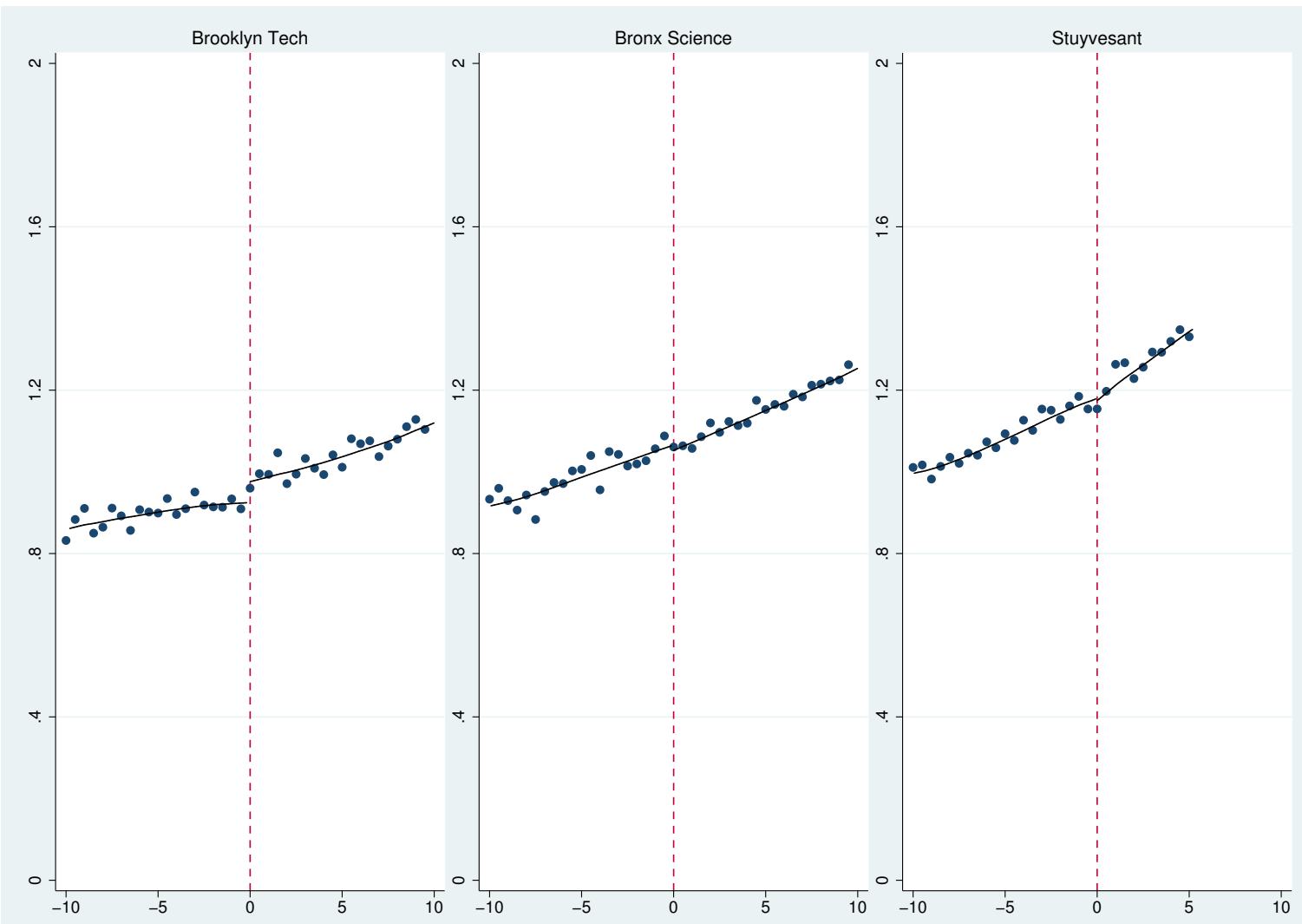

Figure 7B: Regents English at NYC Exam Schools 


\section{References}

AbAdie, A. (2003): "Semiparametric instrumental variables estimation of treatment response models," Journal of Econometrics, 113(2), 231-263.

AbdulkadiroĞlu, A., J. Angrist, and P. Pathak (2011): "The Elite Illusion: Achievement Effects at Boston and New York Exam Schools," NBER Working paper 17264.

AbdulkadiroĞlu, A., P. A. Pathak, and A. E. Roth (2009): "Strategy-proofness versus Efficiency in Matching with Indifferences: Redesigning the New York City High School Match," American Economic Review, 99(5), 1954-1978.

Ammermueller, A., and J.-S. Pischke (2009): "Peer Effects in European Primary Schools: Evidence from the Progress in International Reading Literacy Study," Journal of Labor Economics, $27(3), 315-348$.

Angrist, J. D. (1998): "Estimating the Labor Market Impact of Voluntary Military Service Using Social Security Data on Military Applicants," Econometrica, 66(2), 249-288.

Angrist, J. D., And K. Lang (2004): "Does School Integration Generate Peer Effects? Evidence from Boston's Metco Program," American Economic Review, 94(5), 1613-1634.

Black, S. (1999): "Do Better Schools Matter? Parental Valuation of Elementary Education," Quarterly Journal of Economics, 114(2), 577-599.

Boustan, L. P. (2012): "School Desegregation and Urban Change: Evidence from City Boundaries," American Economic Journal: Applied Economics.

Carrell, S., B. Sacerdote, and J. West (2012): "From Natural Variation to Optimal Policy? An Unsuccessful Experiment in Using Peer Effects Estimates to Improve Student Outcomes," Unpublished paper, UC Davis.

Clarke, D. (2008): "Selective Schools and Academic Achievement," IZA Discussion Paper 3182.

Dale, S., And A. B. Krueger (2002): "Estimating the payoff to attending a more selective college: An application of selection on observables and unobservables," Quarterly Journal of Economics, $117(4), 1491-1527$.

(2011): "Estimating the Return to College Selectivity over the Career Using Administrative Earnings Data," Princeton University, Industrial Relations Working paper, 563.

DesJardins, S., and B. MCCall (2008): "The Impact of Gates Millennium Scholars Program on the Retenion, College Finance- and Work-Related Choices, and Future Educational Aspirations of Low-Income Minority Students," Unpublished manuscript, University of Michigan.

Dobbie, W., And R. G. Fryer (2011): "Exam High Schools and Academic Achievement: Evidence from New York City," NBER Working Paper 17286. 
Duflo, E., P. Dupas, and M. Kremer (2011): "Peer Effects and the Impacts of Tracking: Evidence from a Randomized Evaluation in Kenya," American Economic Review, 101(5), 1739-1774.

Goldin, C., And L. F. Katz (2008): The Race between Education and Technology. Harvard University Press.

Guryan, J. (2004): "Desegregation and Black Dropout Rates," American Economic Review, pp. 919-943.

Hahn, J., P. Todd, And W. van Der KlaAuw (2001): "Identification and Estimation of Treatment Effects with a Regression Discontinuity Design," Econometrica, 69(1), 201-209.

Hanushek, E. A., J. F. Kain, J. M. Markman, and S. G. Rivkin (2003): "Does peer ability affect student achievement?," Journal of Applied Econometrics, 18(5), 527-544.

Hastings, J., T. J. Kane, and D. O. Staiger (2009): "Heterogenous Preferences and the Efficacy of Public School Choice," Working paper, Yale University.

Hernandez, J. (2008): "Racial Imbalance Persists at Elite Public Schools," New York Times, N.Y./Region, November 7.

Hoekstra, M. (2009): "The Effect of Attending the Flagship State University on Earnings: A Discontinuity-Based Approach," Review of Economics and Statistics, 91(4), 717-724.

Hoxby, C. (2000): "Peer Effects in the Classroom: Learning from Gender and Race Variation," NBER Working paper 7867.

Hoxby, C., And G. Weingarth (2006): "Taking race out of the equation: School reassignment and the structure of peer effects," Working paper, Harvard University, Available at: http://www.hks.harvard.edu/inequality/Seminar/Papers/Hoxby06.pdf.

Hsieh, C.-T., and M. Urquiola (2006): "The effects of generalized school choice on achievement and stratification: Evidence from Chile's voucher program," Journal of Public Economics, 90, 14771503.

Imbens, G., and K. Kalyanaraman (2010): "Optimal Bandwidth Choice for the Regression Discontinuity Estimator," CEMMAP Working paper CWP05/10.

Imberman, S. A., A. Kugler, and B. Sacerdote (2012): "Katrina's Children: Evidence on the Structure of Peer Effects from Hurrican Evacuees," forthcoming, American Economic Review.

JACKSON, K. (2010): "Do Students Benefit from Attending Better Schools? Evidence from RuleBased Student Assignments in Trinidad and Tobago," Economic Journal, 120, 1399-1429.

JAN, T. (2006): "Growing a Boston Latin in Brooklyn," Boston Globe, Local Desk, March 4. 
Kane, T. J., And D. O. Staiger (2002): "The Promise and Pitfalls of Using Imprecise School Accountability Measures," Journal of Economic Perspectives, 16(4), 91-114.

Kling, J. R., J. B. Liebman, and L. F. Katz (2007): "Expeirmental Analysis of Neighborhood Effects," Econometrica, pp. 83-119.

Lavy, V., O. Silva, and F. Weinhardt (2009): "The Good, The Bad, and the Average: Evidence on the Scale and Nature of Ability Peer Effects," NBER Working paper, No. 15600.

Lee, D., E. Moretti, And M. J. Butler (2004): "Do Voters Affect or Elect Policies? Evidence from the U.S. House," Quarterly Journal of Economics, 119(3), 807-860.

LEe, D. S. (2009): "Training, Wages, and Sample Selection: Estimating Sharp Bounds on Treatment Effects," RES, 76(3), 1071-1102.

Lee, D. S., and T. Lemieux (2010): "Regression Discontinuity Designs in Economics," Journal of Economic Literature, 48, 281-355.

LutTon, L. (2012): "Chicago will open more selective high schools," WBEZ, Schools on the Line, April 5.

MacLeod, B., and M. Urquiola (2009): "Anti-Lemons: School Reputation and Educational Quality," NBER Working Paper, 15112.

Pathak, P. A., and T. Sönmez (2008): "Leveling the Playing Field: Sincere and Sophisticated Players in the Boston Mechanism," American Economic Review, 98(4), 1636-1652.

(2011): "School Admissions Reform in Chicago and England: Comparing Mechanisms by their Vulnerability to Manipulation," forthcoming, American Economic Review.

Pop-Eleches, C., And M. Urquiola (2010): "Going to a Better School: Effects and Behavioral Responses," Working paper, Columbia University.

Porter, J. (2003): "Estimation in the Regression Discontinuity Model," Working paper, University of Wisconsin.

Rothstein, J. (2006): "Good Principals or Good Peers: Parental Valuation of School Characteristics, Tiebout Equilibrium, and the Incentive Effects of Competition Among Jurisdictions," American Economic Review, 96(4), 1333-1350.

Sanbonmatsu, L., J. Ludwig, L. Katz, L. A. Gennetian, G. J. Duncan, R. C. Kessler, E. A. T. W. McDade, and S. T. Lindau (2011): "Moving to Opportunity for Fair Housing Demonstration Program - Final Impacts Evaluation," US Department of Housing \& Urban Development, PD\&R.

Todd, P., And K. Wolpin (2003): "On the Specification and Estimation of the Production Function for Cognitive Achievement," Economic Journal, 113, F3-F33. 
VAZnis, J. (2009): "Exam School Explore Adding Grade 6," Boston Globe, Education Desk, June 9.

Zhang, H. (2010): "Magnet Schools and Student Achievement: Evidence from a Randomized Natural Experiment in China," Unpublished mimeo, Chinese University of Hong Kong. 


\section{Appendix for "The Elite Illusion: Achievement Effects at Boston and New York Exam Schools"}

\section{A Additional Results for Boston}

Information on Boston's exam school applicants compared to the BPS applicant population is contained in Table A1. Non-exam BPS students are mostly minority and poor enough to qualify for a subsidized lunch. Black and Hispanic students are somewhat under-represented among exam school applicants and students, but most exam school applicants are also poor. Not surprisingly, there are few special education students in an exam school, though many exam school applicants and students are classified as limited English proficient. Exam school applicants are clearly a self-selected group, with markedly higher baseline scores than other BPS students. For example, grade 7 applicants' 4th grade math scores are almost $0.8 \sigma$ higher than those of a typical BPS student. Offered students are even more positively selected, with a score gap of $1.4 \sigma$ in math and $1.3 \sigma$ in English. Similarly large gaps emerge for 9 th graders. Finally, note that there are many more exam school seats in grade 7 than grade 9. As a result, the probability an applicant is offered a seat is much lower for 9th grade applicants.

The figures and estimates with test outcomes were constructed from samples of students who apply to exam schools and for whom we have post-admissions test scores. Students near admissions cutoffs should be similar at the time of application if the regression discontinuity is to approximate an experimental design. Subsequent attrition may lead to differences in the follow-up sample, unless the attrition process is also random. In other words, a threat to our research design is differential and selective attrition by exam offer status. For instance, students just below the cutoff may be less likely to be found than students above the cutoff if students below the cutoff leave the public school system when they do not obtain an exam offer. Differential attrition generates selection bias which in turn may compromise the estimates. One simple test for selection bias is to look at the effect offers have on the likelihood that an applicant contributes MCAS scores to our sample. If differences in follow-up rates are small, then selection bias from differential attrition is also likely to be modest.

Table A2 reports the fraction of exam school applicants with follow-up scores in the discontinuity sample. Between 76-89\% of applicants have a follow-up score. This relatively high follow-up rate is likely due to the requirement that our applicant sample is limited to students who were enrolled in BPS at baseline. Follow-up differentials are estimated using both the parametric and nonparametric approach that parallels the estimates presented in Table 3. Most of the estimated differentials for math and English are small and not significantly different from zero using either the parametric or nonparametric method. While the follow up differential is $2.4-2.7 \%$ in the All Schools column, this difference seems unlikely to explain our findings as the most likely scenario is that relatively high achievers who miss the cutoff exit the public school system.

Another potential concern with our research design is that exam school offers are not the only variable that changes in a discontinuous manner at admissions cutoffs. If covariates other than the ranking of the applicant are used in the assignment mechanism, then these covariates may confound the interpretation of test score differences at cutoffs as being based solely on exam school offers. The fact 
that exam school admissions take place in the BPS central office suggest that it is unlikely that schools have much discretion in selecting which applicants obtain offers at particular schools. Nonetheless, discontinuities in the characteristics of applicants may arise in situations where the admissions process is compromised.

Table A3 briefly examines this possibility. This table shows estimates from models that parallel the reduced-form, but the dependent variables are covariates. There is little evidence of covariate balance across admissions cutoffs. Joint tests of significance of the coefficients suggest the few significant differences in covariates are chance findings.

Finally, Table A4 reports the analog of Table 3 for the sample of blacks and Hispanics in Boston. These results show no clear pattern, though, as noted in the text, there is reasonably strong evidence for a gain in 10th grade ELA scores. There are also some significant negative effects.

\section{B Additional Results for New York}

Information on NYC's exam school applicants compared to 8th graders in NYC public schools is reported in Table B1. As in Boston, New York exam school applicants are positively selected relative to the population of New York 8th graders. Applicants' baseline scores exceed those of other 8th graders by about $0.7-0.8 \sigma$, while the score gap for offered students is $1.7-1.8 \sigma$. Exam school applicants reflect the New York public school population in that a substantial fraction are eligible for a subsidized lunch. In contrast to Boston, however, only about 15\% of New York's offered students are black or Hispanic.

Table B2 reports estimates of NYC follow-up rates following Table A2. The follow-up rate is lowest for math since many applicants take these Regents exams before 9th grade. For the other subjects, the follow-up rates range from $79-87 \%$. For instance, $80 \%$ of students in at least one discontinuity sample have follow up Advanced Math scores, while 87\% have follow-up English scores. While some of the attrition differentials are significantly different from zero at school cutoffs, in the All Schools column, the differences are relatively small. For instance, the follow-up differential for English is about $2 \%$, a result which is only significant with the non-parametric method. Advanced Math and Global History have attrition differences of about 3-4\% in the All Schools model either with the parametric or non-parametric method with most of this difference driven by students from the Brooklyn Technical cutoff.

As in Boston, the NYC admissions process is run in the central office, suggesting limited scope for school discretion in making assignments. In Table B3, we report differences in covariates on either side of cutoffs which parallel those reported in Table A3. While students are more likely to be Hispanic and less likely to obtain a free lunch near the Stuyvesant cutoff, most of these differences are muted with the non-parametric estimates. Even though there are a few small differences at particular school cutoffs, the estimates from the All Schools model do not suggest discontinuous changes in covariates at offer cutoffs. The p-values from the joint test that all covariate discontinuities are significant supports this conclusion in the All Schools model.

New York's exam schools enroll fewer blacks and Hispanic students than in Boston's exam schools. About $7.6 \%$ of enrolled students are black and $6.7 \%$ are Hispanic in New York, compared to $24 \%$ and $15 \%$, respectively for 7 th graders in Boston. Unlike Boston, the NYC results for minorities in Table B4 do not support Regents achievement gains at exam schools. For instance, the impact on English for black or Hispanic students is $0.02 \sigma$ (with standard error 0.04). However, as in Boston, results for high baseline students in NYC offer no evidence of achievement gains for high achievers. 


\section{Boston Data Appendix}

Boston Public Schools is the source for four datasets: the exam school application file, the enrollment file which contains student demographic and school attendance information, the Massachusetts Comprehensive Assessment System (MCAS) test score file, the College Board test file which contains PSAT, SAT and AP scores, and data from the National Student Clearinghouse. This appendix describes these data sets and the procedures used to construct the analysis sample.

\section{C.1 Sources}

\section{Exam school application file}

Data description and sample restrictions

The exam school application file contains a record for each student consisting of a registration number, application year, grade, date of birth, preferences over three exam schools, and scores on the ISEE verbal, quantitative, reading and math sections. Each record also includes the rank of each student by the exam schools on their preference list and the school where the student receives an offer (if any). This dataset covers students in grades 7, 9, and 10 and application years 1997-2008. Since there are a small number of grade 10 applicants, we kept students applying for grades 7 and 9 only.

Table $\mathrm{C} 1$ indicates the steps involved in processing the exam application file. We excluded duplicate observations, applicants from private schools and those who did not rank or were not ranked by any exam school. We also dropped students who obtained an offer at an exam school that is not on their preference list.

Coding the offer variable

For each applicant, the exam school application file indicates whether the student receives an offer at one school on their preference list. For a given application year, grade, and school, we computed the lowest-ranked student to obtain an offer from that school. Each student is then coded as obtaining an offer at an exam school if her score is above this minimum cutoff for any school that is on her preference list.

\section{Enrollment file}

\section{Data description}

The BPS enrollment file spans school years 1995-1996 through 2008-2009. Each record contains an end-of-year (June) snapshot for each student enrolled in Boston Public Schools, with unique student identifier (the BPS ID), the student's grade and school, and demographic information.

\section{Coding of demographics and attendance}

The variables of interest in the enrollment file are grade, year, date of birth, sex, race, special education (SPED) and limited English proficiency (LEP) status, subsidized lunch eligibility, and school. Students are coded as attending an exam school if their year-end enrollment is at an exam school. Years at an exam school is the total number of years where a student is at an exam school at the end of the year. We transformed the enrollment file into a wide-format layout for each student where we compute the grade and exam school years attended for a given year. Finally, we kept only students that attend Boston Public Schools in 6th or 8th grade and use their demographic information from that year. 


\section{MCAS test file}

\section{Data description and sample restrictions}

Each record in the MCAS test file contains a student identifier (BPS ID) and scores on MCAS tests in a given year. We used data from school years 1999-2000 through 2008-2009. The scores we look at are math and English Language Arts (ELA) for grades 4-10. The MCAS test file contains raw scores for all BPS test takers for math, English Language Arts, Writing, and Science. As shown in Table C2, the number of grades tested has increased over time. MCAS Math for grade 8 was the first examination offered in 1999. By the end of our data, there are tests for math and English tests at grade 7, 8, and 10. Baseline scores for grade 7 applicants are from 4 th grade MCAS exams. For 9th grade applicants, baseline math is from 8th grade math and baseline English is from 7th grade English, since the 8th grade English exam is first offered in 2006.

We standardized scores to have mean zero and standard deviation one within a subject-grade-year among all test-takers in Boston Public Schools. When there is more than one test score for a student for a particular subject, we used the first available score. Boston exam offers appear to boost grade repetition at some schools and cohorts, though not consistently. In any case, increased repetition seems likely to boost scores if anything since repetition increases age at test.

\section{College Board test file}

\section{Data description and sample restrictions}

The College Board provides BPS with reports on the test performance of all BPS test-takers from 2004-2005 through 2009-2010. These files come with the name, date of birth, address, gender, school of test, and test year for each exam. BPS matched the PSAT file for October 2004 and October 2005, the SAT file which is available from 2005-2009, and the Advanced Placement test file, available from 2005-2009. The timing of these tests for our applicant cohorts is shown in Table C2.

The PSAT file is not matched to BPS student IDs for years 2006-2009, so we had to link College Board files to BPS files for these years. The address information in the College Board file is entered by the test-taker and does not immediately concord with the BPS address system. There also appear to be small errors in the date of birth in the College Board file for similar reasons. Our procedure to match these files to the BPS registration files is as follows. First, we take all unique year, date of birth, gender, school of test, and zip code matches between the BPS registration file and the College Board PSAT file. Among the remaining unmatched PSAT records, we take all unique year, date of birth, gender, and school of test matches between the two files. Finally, for the remaining unmatched PSAT test records, we hand-matched the records for these four years to the closest record in the registration file, attempting to correct mismatches due to address misspellings or typos in the date of birth.

BPS students take AP exams across a range of subjects. The tests with $500+$ or more takers are Calculus AB, Statistics, Biology, Chemistry, Physics B, English Language and Composition, English Literature and Composition, European History, US Government and Politics, US History, Microeconomics, Macroeconomics, and Spanish Language. The other tests are Art History, Art: Drawing, Art: 2D Design, Art: 3D design, Chinese Language and Culture, Computer Science A, Computer Science AB, Environmental Science, French Language, French Literature, German Language, Comparative Government and Politics, Latin: Vergil, Latin: Literature, Calculus BC, Music Theory, Physics C: Mechanics, Physics C: Electricity and Magnetism, Spanish Literature, and World History.

We standardized the PSAT and SAT scores to have mean zero and standard deviation one within a year among all test-takers in Boston Public Schools. When there is more than one test score for a student, we used the earliest available one. We only use applicant cohorts for whom we might expect to observe PSAT, SAT or AP exams; these are summarized in Table C2. 


\section{National Student Clearinghouse}

Data description and sample restrictions

BPS matches data on seniors to National Student Clearinghouse (NSC) files, which record information on enrollment at over 90 percent of American 4-year colleges and universities. We match these files to the Barron's Profile of American Colleges, provided to us by David Deming in electronic form, to form our list of competitiveness. The most common colleges attended in our sample are Bunker Hill Community College, University of Massachusetts Boston, University of Massachusetts Amherst, Roxbury Community College, Boston University, Massachusetts Bay Community College, Suffolk University, Boston College, Salem State University, and Northeastern University. Table C5 shows the number of applicants we observe with NSC outcomes relative to the number of students we expect (defined as those enrolled in BPS in grade 12).

\section{C.2 Matching Data Sets}

\section{Match from the MCAS test file to the enrollment file}

\section{Match criteria}

The MCAS test file and enrollment files are merged by grade, year, and BPS ID. Any test record that is not be matched to the enrollment file is dropped.

The exam applicant file is matched to the enrollment/MCAS file using an auxiliary table that links exam registration number to BPS ID. This table provides a BPS ID for each exam registration number. For a small number of cases, an exam registration number is matched to more than one BPS ID. In these cases, we matched to the registration number to the BPS ID where the date of birth is the same between the exam applicant and enrollment file.

\section{Match rates}

Table C3 reports match rates from exam applicant file to the enrollment/MCAS file. The overall match rate is 96.6 percent $(13,730$ out of 14,212$)$ for grade 7 applicants and $99.6(6,155$ out of 6,181$)$ for grade 9 applicants. The match rate for offered students in grade 7 is $96.9 \%$, while the match rate for students who were not offered is $96.3 \%$. The lower match rates come from earlier application years 1997-2000. The match rate for not offered is larger than for offered for three of these years, and the differences in match rates are small. For grade 9, where the application cohorts start in 2001, the match rate for offered students is $99.9 \%$, while for non-offered it is $99.5 \%$. Applicants who are not matched to the enrollment file at baseline are dropped as are applicants who enrolled in an exam school before application. This latter restriction only impacts grade 9 applicants, as can be seen comparing columns (7) and (8) of Table C1.

\section{C.3 Construction of the Analysis Sample}

The size of the final analysis sample is presented in column (8) of Table C1.

\section{Stacking grades}

Some of the analysis stacks grades and includes multiple test scores for individual students. For each student in an application year, Table $\mathrm{C} 4$ reports the number of students with at least one follow up test score (column (2)). It also presents the number of test scores expected for each cohort and the number of test scores observed for both math and English. For example, a 7th grade applicant 
for the 2005-2006 school year contributes math scores in grade 7 (Spring 2006), 8 (Spring 2007), and 10 (Spring 2009). Hence, we expect 3,285 math scores from the 1,095 applicants for this cohort, and we observe at least one score for 1,001 students, which corresponds to a total of 2,650 student-score observations. On the other hand, a 7 th grade applicant for the previous school year contributes one fewer test score (no grade 7 math). Table C5 shows a related analysis of expected follow up for PSAT, SAT and AP scores, and the NSC outcomes.

\section{New York Data Appendix}

The New York City Department of Education is the source for three datasets: the exam school application and Student Enrollment Office (formerly, OSEPO) files which contains demographic information, the registration file which contains school attendance information, and the NYSED and Regents test score file. This appendix describes these data sets and details the procedures used to construct the analysis sample.

\section{D.1 Sources}

\section{Exam school application and Enrollment Office files}

\section{Data description and sample restrictions}

The exam school application file is maintained by the Enrollment Office, which runs high school admissions. All applicants must take the Specialized High School Admissions Test (SHSAT) to apply to an exam school. On test day, students also submit a ranking of exam schools. At a later date, students are also required complete a New York City Public High School Admissions Application and submit it to their guidance counselor.

Several Enrollment Office files are used in the analysis. The first contains a record for each student indexed by their ID number (OSISID) and their score on the SHSAT. For each student, the exam school offer file contains a list of the schools ranked and an indicator for the school at which the student obtains an offer (if any). The Enrollment Office student file has demographic information such as grade, sex, race, home language code, and borough of residence for each student. There are also separate files indicating special education and limited English proficiency for each student. Each file for a given application year contains an OSISID number for each student, which allows us to merge the files together.

\section{Registration and enrollment files}

\section{Data description and sample restrictions}

The NYC registration file is from the Office of School Performance and Accountability and is available as part of data underlying school progress reports. The registration and enrollment cover all public school students in grades 9 to 12 for school years 2002-2003 through 2008-2009. This data set includes each student's NYC ID, grade, and current school as of October in the school year. The registration data are used to determine whether and for how many years a student enrolls in an exam school, where a student who is enrolled in October is counted as enrolling for the entire year. Starting in 2004-2005, there is a separate file which contains a list of all students who obtain a subsidized school lunch in that year. This variable is used to code subsidized lunch status for applicants using the application year. For applicants in 2003-2004, 2004-2005, and 2005-2006, we used the lunch status record from 2004-2005. For application cohort in 2006-2007, we used the lunch status record from 2005-2006. 
Table D1 indicates the steps involved in processing the exam application file and merging it with the Student Enrollment files. From the file of exam applicants, we eliminated private school applicants (based on whether their OSISID starts with the letter "A") and those who do not submit a New York City Public School Admissions Application (based on the Round 1 HS ranking file). The 4,000-5,000 private school applicants are excluded because these students do not have a NYC ID at the time of application, they do not have baseline information, and the relevant counterfactual for this population is unlikely to be a regular NYC public high school. We also excluded students who did not rank at least one of the three original academic exam schools: Bronx Science, Brooklyn Technical, and Stuyvesant.

\section{Baseline test files}

\section{Data description and sample restrictions}

The NYC Department of Education also provided us with NYSED grade 8 standardized exams in math and English Language Arts for all public school students for years 2002-2003 through 2007-2008. These tests are taken in the winter of grade 8 and are required of all public school students in the state. These tests serve as our baseline math and English scores.

\section{Regents test file}

\section{Data description and sample restrictions}

The NYC Regents test file contains the date and raw score for each tested student. Regents exams are mandatory state examinations where performance determines whether a student is eligible for a high school diploma in New York. There are Regents examinations in English, Global History, US History, and multiple exams in math and Science. A Regents exam typically has a multiple choice section and a long answer or essay component, and each exam usually lasts for three hours. The English exam, however, consists of two three-hour pieces over two days. The exam has a locally graded component and Dee, Jacob, McCrary, and Rockoff (2011) illustrate how test scores bunch near performance thresholds.

The New York State Board of Regents governs and designs the Regents exams. Starting in 2005, they started to modify the math exams. At the beginning of our sample, the two math exams were Elementary Algebra and Planar Geometry (Math A) and Intermediate Algebra and Trigonometry (Math B). Two new math exams, Integrated Algebra I (Math E) and Geometry (Math G), have since been phased in. Since students typically either take Math A or Math E, we focus on the score on the test taken first, taking the Math A score when both are contemporaneous. Likewise, students typically either take Math B or Math G, so we focus on the score which comes first, taking the Math B score when both are contemporaneous. We denote the first test outcome as 'Math' and the second outcome as 'Advanced Math'. There are Regents science exams in Earth Science, Living Environment, Chemistry, and Physics. The science outcome we focus on is Living Environment because it is the only Regents science exam required to obtain a state high school diploma.

In Table D3, for each test, we report the number of applicants and the number of test scores we observe. English and U.S. History Regents exams are typically taken in 11th grade. For the 2006-2007 applicants, we expect to observe these scores in the 2009-2010, a year after the Regents test score file's last date. Even though there are a small number of students who take these exams before the 11th grade, we do not examine Regents English and U.S. History outcomes for the 2006-2007 applicant cohort, since the vast majority do not.

Since students may take Regents exams multiple times, there can be multiple test scores per student in the Regents test file. Table D3 presents the number of students who have taken each exam 
more than once among the exam applicant sample. This fraction is about $10 \%$, with slightly higher retake rates for math and Global History. Some students may also take Regents exams before exam school enrollment. Table D3 shows the fraction of students who take exams before enrolling in an exam school. A large fraction of exam school applicants take math before enrolling. Most Regents exams are offered in January, June, and August, with most students usually taking tests in June.

For some subjects, such as Global History, most applicants take the test at the end of 10th grade. For other tests, such as math (Math A or E), many students take the exam before entering high school and some students take the exam multiple times. The exact number of students who take the exam before 9 th grade, the number who take the exam more than once after 9th grade, and the number who take the exam on a date other than the most common date are presented in Table D3. For each test where there is a re-take, we only use the first test outcome. New York exam offers do not consistently boost grade repetition.

For each test, students who have scores before the 9th grade are omitted because they tested prior to potential exam enrollment. If a student takes the test more than once after 9th grade, we used the test score from the earliest date. There are a small number of cases where there is more than one score on the same date, and this date is the first date after entering 9 th grade. In some of these cases, there are two different test codes, where one code ends with a "2." We used the score corresponding to the test that does not end with a "2." Otherwise, we treated the score as missing.

For each subject, we standardized scores to have mean zero and standard deviation one within year-semester-subject among the universe of students: 8th graders from public school who participated in Round 1 of the HS Admissions process, have valid demographic information, and did not take the SHSAT test in a previous year.

\section{D.2 Matching Data Sets}

\section{Match between Exam Applicant file and Enrollment Office student file}

We matched the exam application to the student file using the OSISID. Table D2 shows the match rates. Nearly every student who has applied to an exam school can be matched to the corresponding Enrollment Office student file. The student file allows us to identify whether an applicant is in grade 8 or 9 . Since there are a limited number of 9 th grade applicants for grade 10 spots, we kept only students applying for grade 9. Finally, our sample is limited to first-time SHSAT takers.

\section{Coding the offer variable}

For each exam school and applicant year, the exam school offer file indicates the school at which a student obtains an offer (if any). The offered school is the student's most preferred school where a student has a high enough SHSAT score. For each school, we computed the minimum score needed to obtain an offer at each exam school. We coded anyone with an SHSAT score above the lowest score offered as having received an offer.

\section{Coding Attendance}

Students are coded as attending an exam school if they are enrolled at an exam school in the registration file.

\section{D.3 Construction of the Analysis Sample}

After processing the exam application file, we next matched it to the registration file for grade 9. An exam applicant may not match to the registration file if she leaves New York City's Public Schools following application. Such an applicant would not contribute any follow up scores. 
To generate the final analysis dataset, we merged the student registration and test file with the exam application file. The exam application file contains the NYC ID, a list of exam schools that students have ranked, and the student's raw SHSAT test score. This data spans four cycles of admissions years: 2003-04 through 2006-07.

Next, we merged baseline scores for students for whom they are available. Finally, we merged the dataset of cleaned Regents outcome scores. For each test, we compute the implied years of exam school attendance based on the test date and enrollment status. If a student took a Regents test in the fall semester, we computed years assuming the exam date is January 31st. Otherwise, we compute years assuming the exam date is June 1st. The resulting file is our analysis sample. An applicant who is matched to the registration file for grade 9 may not contribute follow up scores if the applicant leaves New York City's Public Schools before taking a Regents exam. The last column of Table D1 indicates the sample of students who contribute at least one follow up score. 


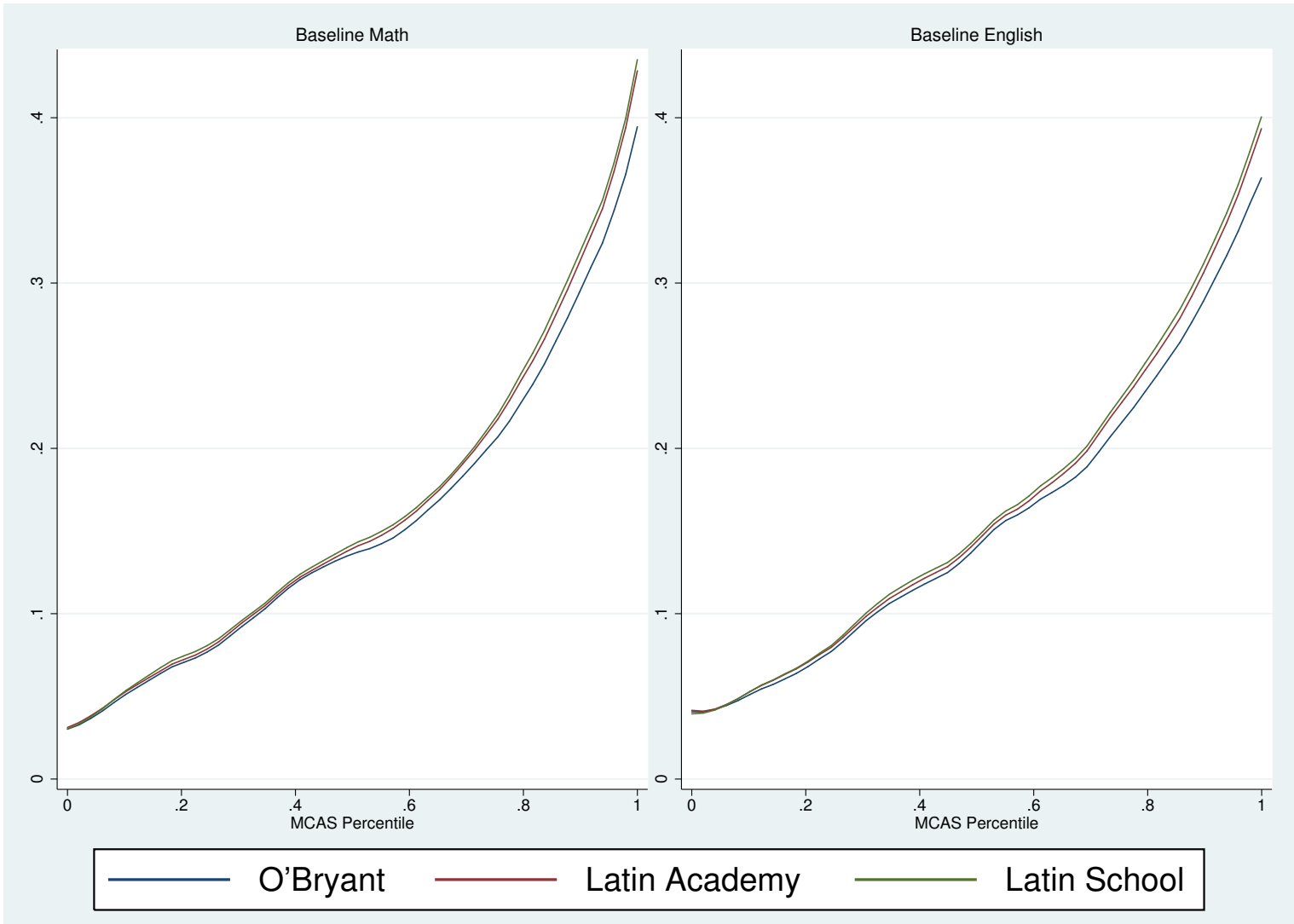

Figure A1: Probability of Applying to Exam School Conditional on Baseline Score (Middle School)

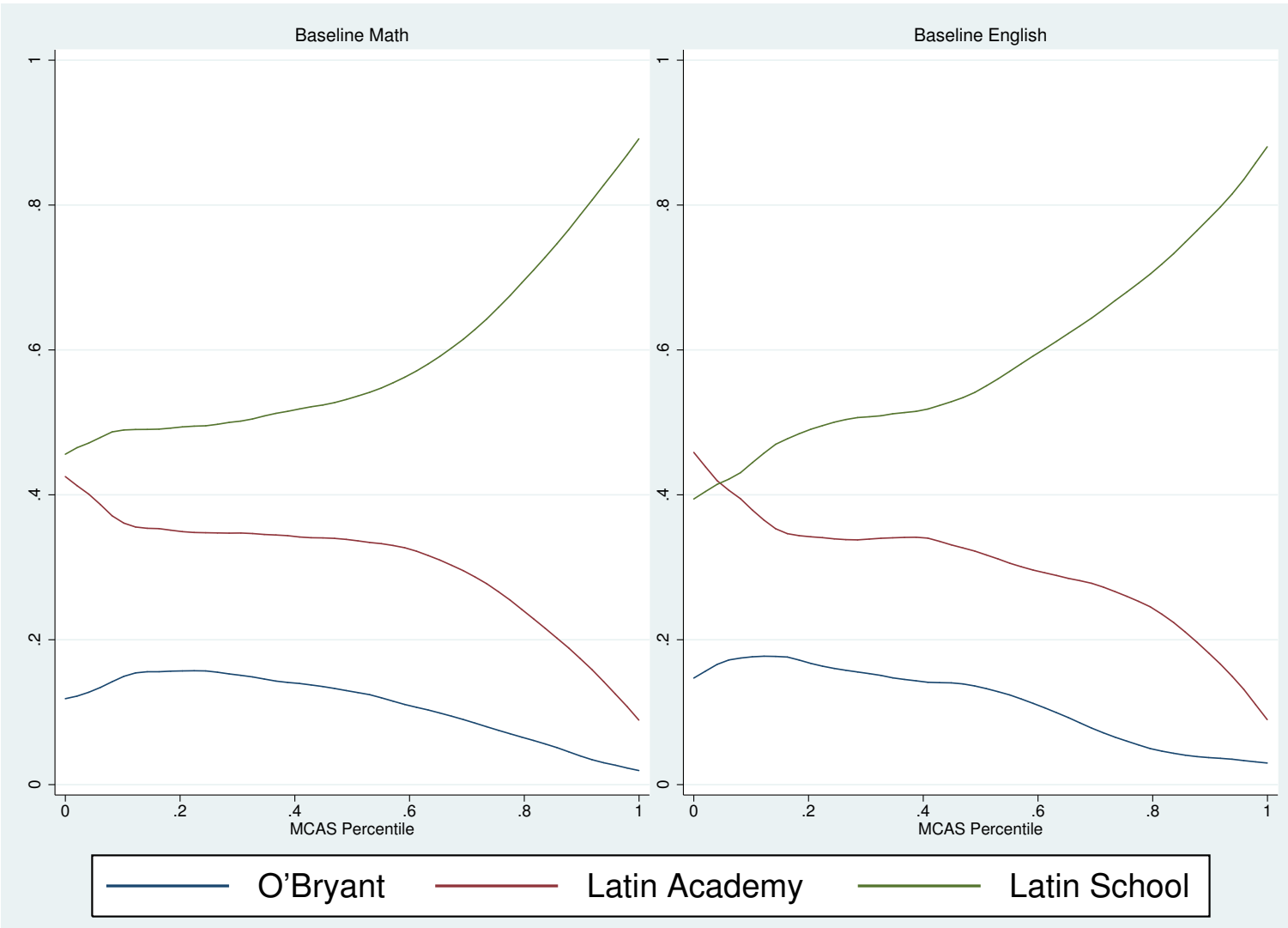

Figure A2: Probability Applicant Ranks Exam School First Conditional on Baseline Score (Middle School) 
Table A1. Descriptive Statistics for Boston Exam School Applicants

\begin{tabular}{|c|c|c|c|c|c|c|c|c|}
\hline & \multicolumn{4}{|c|}{ 7th Grade } & \multicolumn{4}{|c|}{ 9th Grade } \\
\hline & $\begin{array}{c}\text { All } \\
\text { Boston } \\
(1)\end{array}$ & $\begin{array}{c}\text { Exam } \\
\text { Applicants } \\
(2)\end{array}$ & $\begin{array}{c}\text { Offered } \\
\text { Students } \\
(3) \\
\end{array}$ & $\begin{array}{c}\text { Enrolled } \\
\text { Students } \\
(4) \\
\end{array}$ & $\begin{array}{c}\text { All } \\
\text { Boston } \\
(5) \\
\end{array}$ & $\begin{array}{c}\text { Exam } \\
\text { Applicants } \\
(6) \\
\end{array}$ & $\begin{array}{c}\text { Offered } \\
\text { Students } \\
(7) \\
\end{array}$ & $\begin{array}{c}\text { Enrolled } \\
\text { Students } \\
(8) \\
\end{array}$ \\
\hline \multicolumn{9}{|c|}{ A. Demographics } \\
\hline Female & 0.478 & 0.539 & 0.563 & 0.565 & 0.476 & 0.540 & 0.614 & 0.602 \\
\hline Black & 0.476 & 0.376 & 0.240 & 0.237 & 0.505 & 0.493 & 0.361 & 0.367 \\
\hline Hispanic & 0.308 & 0.207 & 0.163 & 0.155 & 0.331 & 0.243 & 0.233 & 0.215 \\
\hline Free Lunch & 0.715 & 0.706 & 0.618 & 0.616 & 0.762 & 0.805 & 0.783 & 0.799 \\
\hline LEP & 0.200 & 0.141 & 0.113 & 0.113 & 0.181 & 0.130 & 0.117 & 0.133 \\
\hline SPED $^{¥}$ & 0.230 & 0.044 & 0.008 & 0.008 & 0.250 & 0.079 & 0.019 & 0.015 \\
\hline $\mathrm{N}$ & 51480 & 11464 & 5441 & 4807 & 30484 & 5540 & 1461 & 1095 \\
\hline \multicolumn{9}{|c|}{ B. Baseline Scores* } \\
\hline Math & -0.017 & 0.758 & 1.399 & 1.436 & -0.313 & 0.227 & 1.036 & 1.058 \\
\hline English & -0.020 & 0.725 & 1.286 & 1.315 & -0.246 & 0.275 & 0.835 & 0.824 \\
\hline $\mathrm{N}$ & 37779 & 9423 & 4577 & 4055 & 27505 & 5461 & 1436 & 1081 \\
\hline
\end{tabular}

Notes: This table reports sample means for 1999-2008. The All Boston sample includes 6th and 8th grade students in Boston public schools who had not previously enrolled in any exam school. Exam Applicants are students with a valid application; offered students are applicants who receive an offer at any exam school; enrolled students are applicants who enrolled at any exam school in the following school year. Baseline Math and English scores for 7th grade applicants are from 4th grade. Baseline scores for 9th grade applicants are from middle school. LEP means Limited English Proficient. SPED means Special Education. $\mathrm{N}$ is the number of observations with at least one non-missing value for the variable listed.

${ }^{*}$ SPED only available for years 1999-2004.

* Baseline scores available from 2000 onward for 6th grade and from 2002 onward for grade 8. 
Table A2. Boston Attrition Differentials

\begin{tabular}{|c|c|c|c|c|c|c|c|c|c|c|}
\hline \multirow[b]{2}{*}{$\begin{array}{l}\text { Application } \\
\text { Grade }\end{array}$} & \multirow[b]{2}{*}{$\begin{array}{l}\text { Test } \\
\text { Grade }\end{array}$} & \multirow[b]{2}{*}{$\begin{array}{l}\text { Fraction with } \\
\text { Follow Up }\end{array}$} & \multicolumn{4}{|c|}{ Parametric Estimates } & \multicolumn{4}{|c|}{ Non-parametric (DM) Estimates } \\
\hline & & & $\begin{array}{c}\text { O'Bryant } \\
\text { (1) }\end{array}$ & $\begin{array}{c}\text { Latin } \\
\text { Academy } \\
(2) \\
\end{array}$ & $\begin{array}{c}\text { Latin } \\
\text { School } \\
(3) \\
\end{array}$ & $\begin{array}{c}\text { All } \\
\text { Schools } \\
(4) \\
\end{array}$ & $\begin{array}{c}\text { O'Bryant } \\
(5)\end{array}$ & $\begin{array}{c}\text { Latin } \\
\text { Academy } \\
(6)\end{array}$ & $\begin{array}{c}\text { Latin } \\
\text { School } \\
(7)\end{array}$ & $\begin{array}{c}\text { All } \\
\text { Schools } \\
(8) \\
\end{array}$ \\
\hline \multirow{3}{*}{7 th } & & & & & & A. Math & & & & \\
\hline & 7th and 8th & 0.875 & $\begin{array}{c}0.049 \\
(0.042)\end{array}$ & $\begin{array}{c}0.058 \\
(0.036)\end{array}$ & $\begin{array}{l}-0.021 \\
(0.035)\end{array}$ & $\begin{array}{c}0.031 \\
(0.026)\end{array}$ & $\begin{array}{c}0.036 \\
(0.024)\end{array}$ & $\begin{array}{c}0.026 \\
(0.020)\end{array}$ & $\begin{array}{c}0.031 \\
(0.022)\end{array}$ & $\begin{array}{l}0.031^{* *} \\
(0.014)\end{array}$ \\
\hline & & 9493 & 4773 & 4842 & 4183 & 13798 & 4249 & 4606 & 3389 & 12244 \\
\hline \multirow[t]{2}{*}{ 7th and 9th } & 10th & 0.759 & $\begin{array}{c}0.078 \\
(0.050)\end{array}$ & $\begin{array}{l}-0.013 \\
(0.056)\end{array}$ & $\begin{array}{c}0.004 \\
(0.055)\end{array}$ & $\begin{array}{c}0.032 \\
(0.031)\end{array}$ & $\begin{array}{c}0.025 \\
(0.029)\end{array}$ & $\begin{array}{l}-0.005 \\
(0.035)\end{array}$ & $\begin{array}{c}0.052 \\
(0.035)\end{array}$ & $\begin{array}{c}0.023 \\
(0.019)\end{array}$ \\
\hline & & 7770 & 4652 & 3613 & 3058 & 11323 & 4243 & 2673 & 2254 & 9170 \\
\hline \multirow[t]{2}{*}{ 7th and 9th } & 7th, 8th, and 10th & 0.823 & $\begin{array}{l}0.063^{*} \\
(0.033)\end{array}$ & $\begin{array}{c}0.027 \\
(0.032)\end{array}$ & $\begin{array}{l}-0.011 \\
(0.031)\end{array}$ & $\begin{array}{c}0.031 \\
(0.023)\end{array}$ & $\begin{array}{c}0.030 \\
(0.019)\end{array}$ & $\begin{array}{c}0.016 \\
(0.017)\end{array}$ & $\begin{array}{l}0.039^{* *} \\
(0.019)\end{array}$ & $\begin{array}{l}0.027^{* *} \\
(0.014)\end{array}$ \\
\hline & & 17263 & 9425 & 8455 & 7241 & 25121 & 8492 & 7279 & 5643 & 21414 \\
\hline 7 th & 7th and 8th & $\begin{array}{l}0.891 \\
9473\end{array}$ & $\begin{array}{c}0.051 \\
(0.039) \\
4784\end{array}$ & $\begin{array}{c}0.070^{* *} \\
(0.035) \\
4880\end{array}$ & $\begin{array}{c}-0.008 \\
(0.032) \\
4160\end{array}$ & $\begin{array}{c}\text { English } \\
0.040 \\
(0.026) \\
13824\end{array}$ & $\begin{array}{c}0.030 \\
(0.022) \\
4531\end{array}$ & $\begin{array}{c}0.035^{*} \\
(0.020) \\
4242\end{array}$ & $\begin{array}{c}0.017 \\
(0.018) \\
3856\end{array}$ & $\begin{array}{c}0.027^{* *} \\
(0.014) \\
12629\end{array}$ \\
\hline \multirow[t]{2}{*}{ 7th and 9th } & 10th & 0.761 & $\begin{array}{l}0.086^{*} \\
(0.050)\end{array}$ & $\begin{array}{l}-0.039 \\
(0.056)\end{array}$ & $\begin{array}{c}0.019 \\
(0.055)\end{array}$ & $\begin{array}{c}0.031 \\
(0.031)\end{array}$ & $\begin{array}{c}0.029 \\
(0.028)\end{array}$ & $\begin{array}{l}-0.029 \\
(0.037)\end{array}$ & $\begin{array}{c}0.051 \\
(0.034)\end{array}$ & $\begin{array}{r}0.020 \\
(0.019)\end{array}$ \\
\hline & & 7770 & 4652 & 3613 & 3058 & 11323 & 4515 & 2351 & 2361 & 9227 \\
\hline \multirow[t]{2}{*}{ 7th and 9th } & 7th, 8th, and 10th & 0.833 & $\begin{array}{l}0.068^{* *} \\
(0.032)\end{array}$ & $\begin{array}{c}0.022 \\
(0.032)\end{array}$ & $\begin{array}{c}0.003 \\
(0.029)\end{array}$ & $\begin{array}{c}0.036 \\
(0.022)\end{array}$ & $\begin{array}{l}0.029^{*} \\
(0.018)\end{array}$ & $\begin{array}{c}0.012 \\
(0.019)\end{array}$ & $\begin{array}{l}0.029^{*} \\
(0.016)\end{array}$ & $\begin{array}{l}0.024^{*} \\
(0.013)\end{array}$ \\
\hline & & 17243 & 9436 & 8493 & 7218 & 25147 & 9046 & 6593 & 6217 & 21856 \\
\hline
\end{tabular}

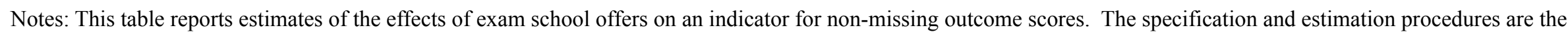

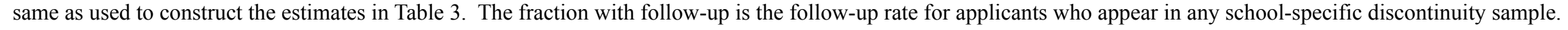

* significant at $10 \% ; *$ significant at $5 \%$; ** significant at $1 \%$ 
Table A3. Boston Covariate Discontinuities

\begin{tabular}{|c|c|c|c|c|c|c|c|c|c|}
\hline \multirow[b]{2}{*}{ Covariate } & \multirow[b]{2}{*}{ Mean } & \multicolumn{3}{|c|}{ Parametric Estimates } & \multirow[b]{2}{*}{$\begin{array}{c}\text { All } \\
\text { Schools } \\
(5) \\
\end{array}$} & \multicolumn{4}{|c|}{ Non-parametric (DM) Estimates } \\
\hline & & $\begin{array}{c}\text { O'Bryant } \\
(1)\end{array}$ & $\begin{array}{c}\text { Latin } \\
\text { Academy } \\
(2)\end{array}$ & $\begin{array}{c}\text { Latin } \\
\text { School } \\
(3)\end{array}$ & & $\begin{array}{c}\text { O'Bryant } \\
(5)\end{array}$ & $\begin{array}{c}\text { Latin } \\
\text { Academy } \\
(6)\end{array}$ & $\begin{array}{c}\text { Latin } \\
\text { School } \\
(7)\end{array}$ & $\begin{array}{c}\text { All } \\
\text { Schools } \\
(8)\end{array}$ \\
\hline & \multicolumn{9}{|c|}{ A. 7th Grade Applicants } \\
\hline \multirow[t]{3}{*}{ Female } & 0.567 & -0.055 & -0.029 & -0.023 & -0.037 & -0.023 & 0.054 & 0.054 & 0.022 \\
\hline & & $(0.061)$ & $(0.065)$ & $(0.070)$ & $(0.037)$ & $(0.036)$ & $(0.041)$ & $(0.043)$ & $(0.024)$ \\
\hline & 7317 & 3694 & 3725 & 3232 & 10651 & 3367 & 2755 & 2441 & 8563 \\
\hline \multirow[t]{3}{*}{ Black } & 0.312 & 0.060 & 0.024 & 0.009 & 0.033 & -0.025 & 0.042 & 0.026 & 0.016 \\
\hline & & $(0.058)$ & $(0.060)$ & $(0.056)$ & $(0.034)$ & $(0.036)$ & $(0.031)$ & $(0.030)$ & $(0.019)$ \\
\hline & 7309 & 3693 & 3722 & 3225 & 10640 & 3264 & 3722 & 3225 & 10211 \\
\hline \multirow[t]{3}{*}{ Hispanic } & 0.195 & -0.051 & -0.061 & -0.074 & $-0.061 * *$ & -0.012 & -0.038 & -0.023 & -0.024 \\
\hline & & $(0.051)$ & $(0.054)$ & $(0.053)$ & $(0.030)$ & $(0.028)$ & $(0.029)$ & $(0.031)$ & $(0.017)$ \\
\hline & 7309 & 3693 & 3722 & 3225 & 10640 & 3693 & 3722 & 2971 & 10386 \\
\hline \multirow[t]{3}{*}{ Free Lunch } & 0.682 & 0.013 & $-0.130 * *$ & $-0.123 *$ & $-0.074 * *$ & 0.011 & $-0.078 * * *$ & -0.043 & $-0.035 * *$ \\
\hline & & $(0.049)$ & $(0.056)$ & $(0.064)$ & $(0.031)$ & $(0.027)$ & $(0.030)$ & $(0.035)$ & $(0.018)$ \\
\hline & 7317 & 3694 & 3725 & 3232 & 10651 & 3694 & 3725 & 3232 & 10651 \\
\hline \multirow[t]{3}{*}{$\mathrm{LEP}^{\mp}$} & 0.126 & -0.015 & -0.023 & $-0.138 * * *$ & $-0.054 * *$ & 0.017 & -0.025 & $-0.077 * * *$ & $-0.023 *$ \\
\hline & & $(0.042)$ & $(0.043)$ & $(0.037)$ & $(0.024)$ & $(0.023)$ & $(0.026)$ & $(0.021)$ & $(0.014)$ \\
\hline & 7317 & 3694 & 3725 & 3232 & 10651 & 3694 & 2856 & 3087 & 9637 \\
\hline \multirow[t]{3}{*}{ SPED $^{*}$} & 0.015 & -0.018 & -0.014 & -0.004 & -0.012 & -0.017 & -0.004 & 0.010 & -0.004 \\
\hline & & $(0.029)$ & $(0.015)$ & $(0.018)$ & $(0.013)$ & $(0.014)$ & $(0.008)$ & $(0.008)$ & $(0.006)$ \\
\hline & 4493 & 2311 & 2249 & 1982 & 6542 & 2226 & 2249 & 1982 & 6457 \\
\hline \multirow[t]{2}{*}{ Joint p-value } & & 0.758 & 0.228 & 0.003 & 0.028 & 0.756 & 0.037 & 0.004 & 0.169 \\
\hline & \multicolumn{9}{|c|}{ B. 9th Grade Applicants } \\
\hline \multirow[t]{3}{*}{ Female } & 0.602 & -0.049 & -0.017 & 0.009 & -0.032 & 0.035 & -0.064 & -0.034 & -0.005 \\
\hline & & $(0.084)$ & $(0.116)$ & $(0.169)$ & $(0.064)$ & $(0.049)$ & $(0.064)$ & $(0.099)$ & $(0.036)$ \\
\hline & 2525 & 1978 & 978 & 754 & 3710 & 1875 & 978 & 501 & 3354 \\
\hline \multirow[t]{3}{*}{ Black } & 0.415 & 0.040 & 0.054 & -0.066 & 0.029 & 0.003 & 0.029 & -0.096 & -0.006 \\
\hline & & $(0.084)$ & $(0.111)$ & $(0.130)$ & $(0.061)$ & $(0.045)$ & $(0.087)$ & $(0.080)$ & $(0.036)$ \\
\hline & 2522 & 1975 & 975 & 751 & 3701 & 1975 & 491 & 489 & 2955 \\
\hline \multirow[t]{3}{*}{ Hispanic } & 0.232 & -0.074 & 0.075 & -0.069 & -0.031 & -0.005 & 0.047 & 0.032 & 0.013 \\
\hline & & $(0.071)$ & $(0.101)$ & $(0.134)$ & $(0.054)$ & $(0.043)$ & $(0.066)$ & $(0.090)$ & $(0.033)$ \\
\hline & 2522 & 1975 & 975 & 751 & 3701 & 1787 & 651 & 402 & 2840 \\
\hline \multirow[t]{3}{*}{ Free Lunch } & 0.789 & -0.056 & 0.020 & $-0.309 * *$ & -0.069 & -0.001 & 0.076 & -0.011 & 0.026 \\
\hline & & $(0.069)$ & $(0.085)$ & $(0.147)$ & $(0.051)$ & $(0.045)$ & $(0.050)$ & $(0.092)$ & $(0.031)$ \\
\hline & 2525 & 1978 & 978 & 754 & 3710 & 1561 & 978 & 396 & 2935 \\
\hline \multirow[t]{3}{*}{ LEP } & 0.118 & 0.000 & -0.087 & 0.027 & -0.021 & 0.023 & -0.020 & 0.029 & 0.011 \\
\hline & & $(0.057)$ & $(0.074)$ & $(0.092)$ & $(0.042)$ & $(0.033)$ & $(0.043)$ & $(0.054)$ & $(0.024)$ \\
\hline & 2525 & 1978 & 978 & 754 & 3710 & 1899 & 903 & 389 & 3191 \\
\hline \multirow[t]{3}{*}{ SPED $^{*}$} & 0.026 & 0.028 & -0.002 & -0.068 & 0.007 & -0.002 & -0.008 & -0.013 & -0.005 \\
\hline & & $(0.038)$ & $(0.027)$ & $(0.046)$ & $(0.024)$ & $(0.021)$ & $(0.013)$ & $(0.035)$ & $(0.015)$ \\
\hline & 1364 & 1045 & 537 & 427 & 2009 & 1045 & 349 & 368 & 1762 \\
\hline Joint p-value & & 0.827 & 0.894 & 0.304 & 0.872 & 0.985 & 0.602 & 0.907 & 0.985 \\
\hline
\end{tabular}

Notes: This table reports estimated discontinuities in covariates using models like those used to construct the reduced form estimates in Table 3 . The joint p-value is from a F-test looking at all covariate discontinuities at once.

${ }^{*}$ SPED only available for years 1999-2004.

* significant at $10 \% ; *$ significant at $5 \%$;** significant at $1 \%$ 
Table A4. Boston Reduced Form Estimates for Blacks and Hispanics: MCAS Math and English

\begin{tabular}{|c|c|c|c|c|c|c|c|c|c|}
\hline \multirow[b]{2}{*}{$\begin{array}{l}\text { Application } \\
\text { Grade }\end{array}$} & \multirow[b]{2}{*}{$\begin{array}{l}\text { Test } \\
\text { Grade }\end{array}$} & \multicolumn{4}{|c|}{ Parametric Estimates } & \multicolumn{4}{|c|}{ Non-parametric (DM) Estimates } \\
\hline & & $\begin{array}{c}\text { O'Bryant } \\
\text { (1) }\end{array}$ & $\begin{array}{c}\text { Latin } \\
\text { Academy } \\
(2)\end{array}$ & $\begin{array}{c}\text { Latin } \\
\text { School } \\
(3)\end{array}$ & $\begin{array}{c}\text { All } \\
\text { Schools } \\
(4)\end{array}$ & $\begin{array}{c}\text { O'Bryant } \\
(5)\end{array}$ & $\begin{array}{c}\text { Latin } \\
\text { Academy } \\
(6)\end{array}$ & $\begin{array}{c}\text { Latin } \\
\text { School } \\
(7)\end{array}$ & $\begin{array}{c}\text { All } \\
\text { Schools } \\
(8)\end{array}$ \\
\hline 7th & 7th and 8th & $\begin{array}{c}-0.250^{* *} \\
(0.127) \\
2580\end{array}$ & $\begin{array}{c}-0.120 \\
(0.110) \\
2211\end{array}$ & $\begin{array}{c}-0.129 \\
(0.164) \\
1308\end{array}$ & $\begin{array}{r}\text { Pane } \\
-0.178^{* *} \\
(0.075) \\
6099\end{array}$ & $\begin{array}{c}\text { Math } \\
-0.143 * \\
(0.077) \\
2206\end{array}$ & $\begin{array}{c}-0.110 \\
(0.084) \\
1986\end{array}$ & $\begin{array}{c}-0.042 \\
(0.089) \\
1291\end{array}$ & $\begin{array}{c}-0.108 * * \\
(0.044) \\
5483\end{array}$ \\
\hline 7th and 9th & 10th & $\begin{array}{c}0.046 \\
(0.097) \\
2234\end{array}$ & $\begin{array}{c}-0.178 \\
(0.111) \\
1444\end{array}$ & $\begin{array}{c}-0.048 \\
(0.074) \\
903\end{array}$ & $\begin{array}{c}-0.042 \\
(0.068) \\
4581\end{array}$ & $\begin{array}{c}0.029 \\
(0.065) \\
1806\end{array}$ & $\begin{array}{c}-0.118^{*} \\
(0.068) \\
1087\end{array}$ & $\begin{array}{c}-0.084 * \\
(0.048) \\
672\end{array}$ & $\begin{array}{c}-0.038 \\
(0.044) \\
3565\end{array}$ \\
\hline 7th and 9th & 7th, 8th, and 10th & $\begin{array}{c}-0.112 \\
(0.089) \\
4814\end{array}$ & $\begin{array}{c}-0.144 * \\
(0.082) \\
3655\end{array}$ & $\begin{array}{c}-0.099 \\
(0.114) \\
2211\end{array}$ & $\begin{array}{c}-0.120^{* *} \\
(0.055) \\
10680\end{array}$ & $\begin{array}{c}-0.068 \\
(0.059) \\
4012\end{array}$ & $\begin{array}{c}-0.113 * * \\
(0.053) \\
3073\end{array}$ & $\begin{array}{c}-0.056 \\
(0.068) \\
1963\end{array}$ & $\begin{array}{c}-0.081 * * * \\
(0.031) \\
9048\end{array}$ \\
\hline 7th & 7th and 8th & $\begin{array}{c}-0.053 \\
(0.090) \\
2640\end{array}$ & $\begin{array}{c}-0.175^{* *} \\
(0.089) \\
2260\end{array}$ & $\begin{array}{c}-0.255^{* *} \\
(0.102) \\
1312\end{array}$ & $\begin{array}{r}\text { Panel } \\
-0.141^{* *} \\
(0.059) \\
6212\end{array}$ & $\begin{array}{l}\text { English } \\
-0.049 \\
(0.048) \\
2544\end{array}$ & $\begin{array}{c}-0.015 \\
(0.062) \\
2204\end{array}$ & $\begin{array}{c}-0.124^{* *} \\
(0.054) \\
1312\end{array}$ & $\begin{array}{c}-0.055 \\
(0.034) \\
6060\end{array}$ \\
\hline 7th and 9th & 10th & $\begin{array}{c}0.150 \\
(0.100) \\
2244\end{array}$ & $\begin{array}{c}0.240^{* *} \\
(0.109) \\
1446\end{array}$ & $\begin{array}{c}-0.095 \\
(0.133) \\
904\end{array}$ & $\begin{array}{c}0.136^{*} \\
(0.073) \\
4594\end{array}$ & $\begin{array}{c}0.180^{* * *} \\
(0.059) \\
2101\end{array}$ & $\begin{array}{c}0.218 * * * \\
(0.076) \\
955\end{array}$ & $\begin{array}{c}0.046 \\
(0.083) \\
675\end{array}$ & $\begin{array}{c}0.166^{* * *} \\
(0.043) \\
3731\end{array}$ \\
\hline 7th and 9th & 7th, 8th, and 10th & $\begin{array}{c}0.041 \\
(0.076) \\
4884\end{array}$ & $\begin{array}{c}-0.006 \\
(0.084) \\
3706\end{array}$ & $\begin{array}{c}-0.198 * * \\
(0.093) \\
2216\end{array}$ & $\begin{array}{c}-0.024 \\
(0.055) \\
10806\end{array}$ & $\begin{array}{c}0.051 \\
(0.042) \\
4645\end{array}$ & $\begin{array}{c}0.055 \\
(0.058) \\
3159\end{array}$ & $\begin{array}{c}-0.072 \\
(0.051) \\
1987\end{array}$ & $\begin{array}{c}0.026 \\
(0.031) \\
9791\end{array}$ \\
\hline
\end{tabular}

Notes: This table reports estimates of the effects of exam school offers on MCAS scores. The sample covers students within 20 standardized units of offer cutoffs. Parametric models include a cubic function of the running variable, allowed to differ on either side of offer cutoffs. Non-parametric estimates use the edge kernel, with bandwidth computed following DesJardins \& McCall (2008). Optimal bandwidths were computed separately for each school. Robust standard errors, clustered on year and school are shown in parentheses. Standard errors for all school estimates and for those pooling outcomes also cluster on student. The number of observations is reported below standard errors.

* significant at $10 \% ; *$ significant at $5 \% ; * *$ significant at $1 \%$ 
Table B1. Descriptive Statistics for NYC Exam School Applicants

\begin{tabular}{|c|c|c|c|c|c|c|c|}
\hline & \multirow[b]{2}{*}{$\begin{array}{c}\text { All } \\
\text { NYC } \\
(1)\end{array}$} & \multicolumn{3}{|c|}{ Any Exam } & \multicolumn{3}{|c|}{ Enrolled in } \\
\hline & & $\begin{array}{c}\text { Exam } \\
\text { Applicants } \\
\text { (2) }\end{array}$ & $\begin{array}{c}\text { Offered } \\
\text { Students } \\
(3)\end{array}$ & $\begin{array}{c}\text { Enrolled } \\
\text { Students } \\
(4)\end{array}$ & $\begin{array}{c}\text { Brooklyn } \\
\text { Tech } \\
(5)\end{array}$ & $\begin{array}{c}\text { Bronx } \\
\text { Science } \\
(6)\end{array}$ & $\begin{array}{c}\text { Stuyvesant } \\
\text { (7) }\end{array}$ \\
\hline & \multicolumn{7}{|c|}{ A. Demographics } \\
\hline Female & 0.487 & 0.503 & 0.456 & 0.426 & 0.415 & 0.443 & 0.429 \\
\hline Black & 0.336 & 0.299 & 0.078 & 0.076 & 0.133 & 0.040 & 0.019 \\
\hline Hispanic & 0.377 & 0.248 & 0.073 & 0.067 & 0.089 & 0.070 & 0.030 \\
\hline Free Lunch \# & 0.667 & 0.685 & 0.671 & 0.681 & 0.664 & 0.682 & 0.706 \\
\hline LEP & 0.125 & 0.039 & 0.004 & 0.005 & 0.007 & 0.003 & 0.003 \\
\hline SPED & 0.089 & 0.006 & 0.000 & 0.000 & 0.000 & 0.000 & 0.000 \\
\hline \multirow[t]{2}{*}{$\mathrm{N}$} & 453233 & 84539 & 11914 & 9364 & 4255 & 2405 & 2704 \\
\hline & \multicolumn{7}{|c|}{ B. Baseline Scores } \\
\hline Math & -0.004 & 0.779 & 1.780 & 1.802 & 1.619 & 1.771 & 2.119 \\
\hline English & -0.005 & 0.709 & 1.714 & 1.667 & 1.426 & 1.666 & 2.047 \\
\hline $\mathrm{N}$ & 349817 & 82527 & 11841 & 9312 & 4231 & 2397 & 2684 \\
\hline
\end{tabular}

Notes: This table reports sample means for 2004-2007. The All NYC sample includes 8th graders in NYC public schools. Exam applicants are students who applied to Brooklyn Tech, Bronx Science, or Stuyvesant. Offered students are applicants offered a seat at any of these schools. Enrolled students are applicants who register at one of these schools in the year following application. Baseline scores are from 8th grade NYSED Math and Reading.

\# For applicants in 2004 and 2005, free lunch status is from school year 2004-2005 (after assignment), while for applicants in 2006 and 2007, free lunch status is from school year 2004-2005 and 2005-2006 (before assignment). 
Table B2. New York Attrition Differentials

\begin{tabular}{|c|c|c|c|c|c|c|c|c|c|}
\hline & \multirow[b]{2}{*}{$\begin{array}{l}\text { Fraction with } \\
\text { Follow Up }\end{array}$} & \multicolumn{4}{|c|}{ Parametric Estimates } & \multicolumn{4}{|c|}{ Non-parametric (DM) Estimates } \\
\hline & & $\begin{array}{c}\text { Brooklyn } \\
\text { Tech } \\
(1) \\
\end{array}$ & $\begin{array}{c}\text { Bronx } \\
\text { Science } \\
(2)\end{array}$ & $\begin{array}{c}\text { Stuyvesant } \\
\text { (3) }\end{array}$ & $\begin{array}{l}\text { All Schools } \\
(4) \\
\end{array}$ & $\begin{array}{c}\text { Brooklyn } \\
\text { Tech } \\
(5) \\
\end{array}$ & $\begin{array}{c}\text { Bronx } \\
\text { Science } \\
(6)\end{array}$ & $\begin{array}{c}\text { Stuyvesant } \\
(7) \\
\end{array}$ & $\begin{array}{c}\text { All } \\
\text { Schools } \\
(8)\end{array}$ \\
\hline \multirow[t]{3}{*}{ Math } & 0.535 & -0.068 & 0.04 & 0.042 & 0.005 & 0.016 & 0.016 & $0.053 *$ & $0.026^{*}$ \\
\hline & & $(0.043)$ & $(0.045)$ & $(0.043)$ & $(0.025)$ & $(0.026)$ & $(0.023)$ & $(0.029)$ & $(0.015)$ \\
\hline & 18782 & 9181 & 8192 & 8434 & 25807 & 7126 & 8192 & 5757 & 21075 \\
\hline \multirow[t]{3}{*}{ Advanced Math } & 0.799 & $0.101 * * *$ & 0.038 & -0.027 & $0.036^{*}$ & $0.074 * * *$ & 0.022 & 0.008 & $0.033 * * *$ \\
\hline & & $(0.039)$ & $(0.035)$ & $(0.030)$ & $(0.020)$ & $(0.024)$ & $(0.018)$ & $(0.019)$ & $(0.012)$ \\
\hline & 18782 & 9181 & 8192 & 8434 & 25807 & 6586 & 8192 & 6141 & 20919 \\
\hline \multirow[t]{3}{*}{ English } & 0.871 & 0.014 & 0.054 & 0.016 & 0.027 & 0.026 & 0.02 & $0.026^{*}$ & $0.024 * *$ \\
\hline & & $(0.035)$ & $(0.033)$ & $(0.029)$ & $(0.018)$ & $(0.018)$ & $(0.018)$ & $(0.015)$ & $(0.010)$ \\
\hline & 13897 & 7032 & 6335 & 6309 & 19676 & 7032 & 6335 & 6309 & 19676 \\
\hline \multirow[t]{3}{*}{ Global History } & 0.862 & $0.064 *$ & $0.052 *$ & 0.022 & $0.045^{* * *}$ & $0.059 * * *$ & 0.017 & 0.019 & $0.031 * * *$ \\
\hline & & $(0.034)$ & $(0.030)$ & $(0.026)$ & $(0.017)$ & $(0.018)$ & $(0.015)$ & $(0.016)$ & $(0.010)$ \\
\hline & 18782 & 9181 & 8192 & 8434 & 25807 & 8407 & 8192 & 6506 & 23105 \\
\hline \multirow[t]{3}{*}{ US History } & 0.810 & 0.029 & 0.06 & -0.016 & 0.023 & $0.044^{*}$ & 0.031 & 0.009 & $0.029 * *$ \\
\hline & & $(0.042)$ & $(0.040)$ & $(0.033)$ & $(0.022)$ & $(0.026)$ & $(0.021)$ & $(0.021)$ & $(0.013)$ \\
\hline & 13897 & 7032 & 6335 & 6309 & 19676 & 5121 & 6335 & 4472 & 15928 \\
\hline \multirow[t]{3}{*}{ Living Environment } & 0.794 & -0.015 & 0.041 & 0.035 & 0.020 & $0.032 *$ & 0.012 & 0.004 & 0.016 \\
\hline & & $(0.037)$ & $(0.035)$ & $(0.033)$ & $(0.020)$ & $(0.019)$ & $(0.020)$ & $(0.016)$ & $(0.011)$ \\
\hline & 18782 & 9181 & 8192 & 8434 & 25807 & 9181 & 7017 & 8434 & 24632 \\
\hline
\end{tabular}

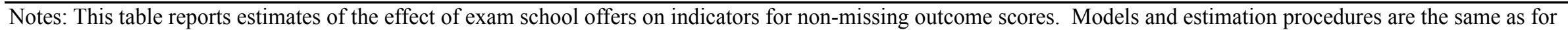

Table 8. The fraction with follow-up is the follow-up rate for applicants who appear in any school-specific discontinuity sample.

*significant at $10 \% ; * *$ significant at $5 \% ; * * *$ significant at $1 \%$. 
Table B3. New York Covariate Discontinuities

\begin{tabular}{|c|c|c|c|c|c|c|c|c|c|}
\hline & \multirow[b]{2}{*}{$\begin{array}{l}\text { Mean of } \\
\text { Variable }\end{array}$} & \multicolumn{4}{|c|}{ Parametric Estimates } & \multicolumn{4}{|c|}{ Non-parametric (DM) Estimates } \\
\hline & & $\begin{array}{c}\text { Brooklyn Tech } \\
(1) \\
\end{array}$ & $\begin{array}{c}\text { Bronx Science } \\
(2) \\
\end{array}$ & $\begin{array}{c}\text { Stuyvesant } \\
\text { (3) } \\
\end{array}$ & $\begin{array}{l}\text { All Schools } \\
(4) \\
\end{array}$ & $\begin{array}{c}\text { Brooklyn Tech } \\
(5) \\
\end{array}$ & $\begin{array}{c}\text { Bronx Science } \\
(6) \\
\end{array}$ & $\begin{array}{c}\text { Stuyvesant } \\
(7) \\
\end{array}$ & $\begin{array}{c}\text { All Schools } \\
(8) \\
\end{array}$ \\
\hline \multirow[t]{3}{*}{ Female } & 0.469 & -0.005 & -0.003 & 0.012 & 0.002 & -0.006 & -0.013 & -0.018 & -0.012 \\
\hline & & $(0.044)$ & $(0.045)$ & $(0.043)$ & $(0.025)$ & $(0.022)$ & $(0.027)$ & $(0.022)$ & $(0.014)$ \\
\hline & 18782 & 9181 & 8192 & 8434 & 25807 & 9181 & 6768 & 8434 & 24383 \\
\hline \multirow[t]{3}{*}{ Black } & 0.109 & -0.046 & -0.002 & 0.023 & -0.008 & $-0.033 *$ & -0.002 & 0.014 & -0.006 \\
\hline & & $(0.032)$ & $(0.028)$ & $(0.021)$ & $(0.016)$ & $(0.018)$ & $(0.015)$ & $(0.011)$ & $(0.009)$ \\
\hline & 18782 & 9181 & 8192 & 8434 & 25807 & 7699 & 8192 & 7667 & 23558 \\
\hline \multirow[t]{3}{*}{ Hispanic } & 0.107 & 0.030 & -0.012 & $0.055 * * *$ & 0.025 & $0.032 * *$ & -0.013 & 0.005 & 0.008 \\
\hline & & $(0.031)$ & $(0.028)$ & $(0.020)$ & $(0.015)$ & $(0.016)$ & $(0.014)$ & $(0.011)$ & $(0.009)$ \\
\hline & 18782 & 9181 & 8192 & 8434 & 25807 & 9181 & 8192 & 7786 & 25159 \\
\hline \multirow[t]{3}{*}{ Free Lunch ${ }^{\#}$} & 0.669 & -0.013 & 0.058 & $-0.091 * *$ & -0.018 & -0.008 & $0.042 *$ & -0.034 & 0.001 \\
\hline & & $(0.041)$ & $(0.042)$ & $(0.040)$ & $(0.024)$ & $(0.022)$ & $(0.022)$ & $(0.022)$ & $(0.013)$ \\
\hline & 18782 & 9181 & 8192 & 8434 & 25807 & 9139 & 8192 & 7944 & 25275 \\
\hline \multirow[t]{3}{*}{ LEP } & 0.005 & $0.012 * *$ & -0.002 & 0.001 & 0.004 & 0.000 & -0.003 & -0.002 & -0.002 \\
\hline & & $(0.006)$ & $(0.004)$ & $(0.005)$ & $(0.003)$ & $(0.003)$ & $(0.003)$ & $(0.002)$ & $(0.002)$ \\
\hline & 18782 & 9181 & 8192 & 8434 & 25807 & 8703 & 6675 & 8434 & 23812 \\
\hline \multicolumn{10}{|l|}{ Joint test: } \\
\hline p-value & & 0.228 & 0.775 & 0.016 & 0.393 & 0.262 & 0.316 & 0.384 & 0.722 \\
\hline
\end{tabular}

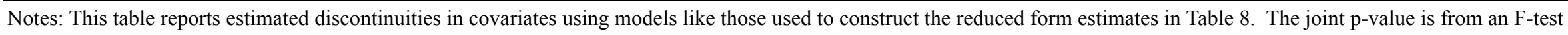
looking at all covariate discontinuities at once.

* significant at $10 \%$; ** significant at $5 \%$; ** significant at $1 \%$. 
Table B4. New York Reduced Form Estimates for Subgroups

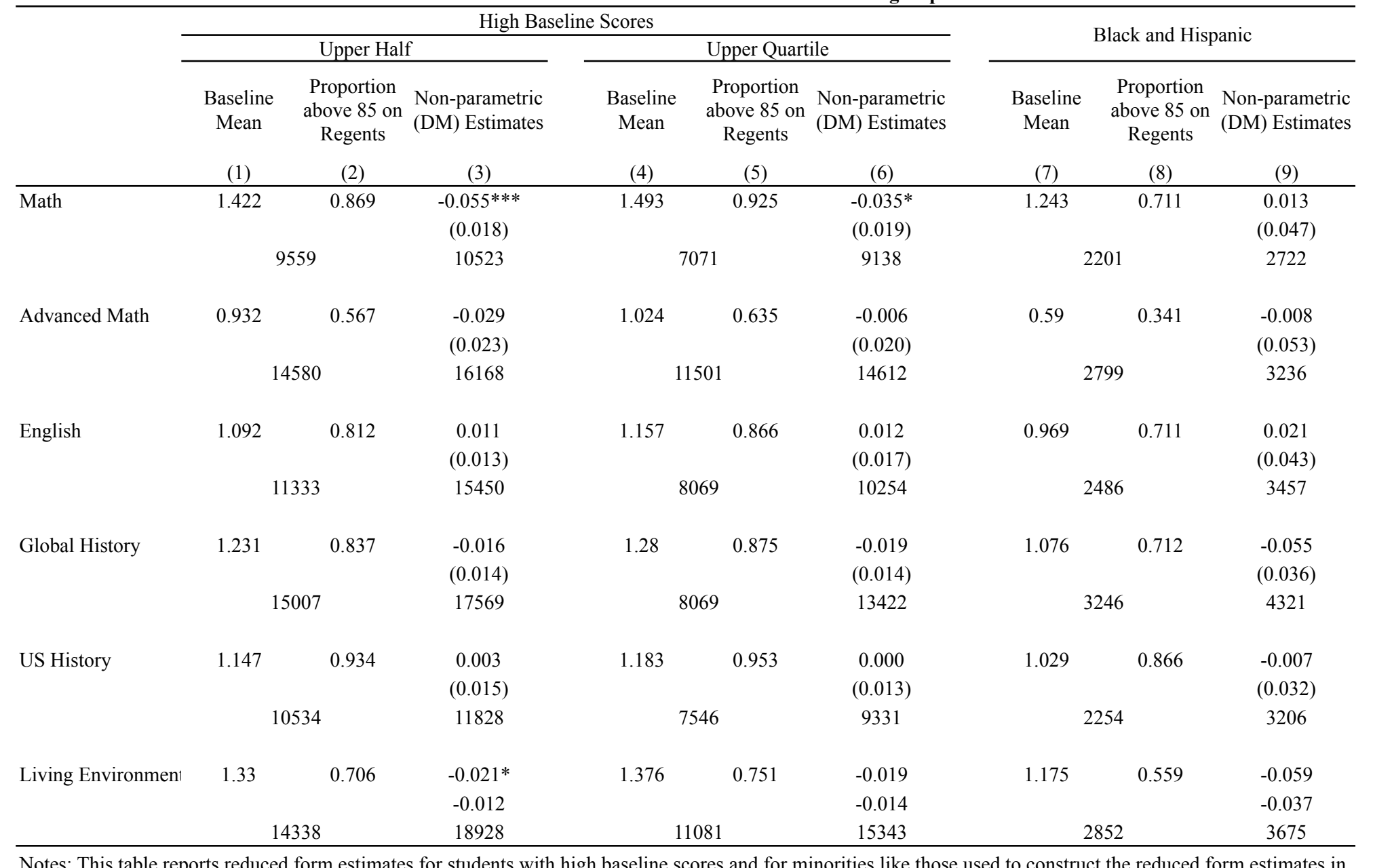

Notes: This table reports reduced form estimates for students with high baseline scores and for minorities like those used to construct the reduced form estimates in Table 8. Baseline means and the proportion of applicants above 85 are computed for those who belong to at least one discontinuity sample. Math scores are from either Regents Math A (Elementary Algebra and Planar Geometry) or Integrated Algebra I. Advanced Math scores are from either Regents Math B (Intermediate Algebra and Trigonometry) or Geometry.

* significant at $10 \% ; *$ significant at $5 \% ; * *$ significant at $1 \%$ 
Table C1. Processing of Boston Exam School Application Data

\begin{tabular}{|c|c|c|c|c|c|c|c|c|c|}
\hline $\begin{array}{c}\text { Application } \\
\text { Year }\end{array}$ & $\begin{array}{c}\text { Total number } \\
\text { of records } \\
\text { (1) }\end{array}$ & $\begin{array}{l}\text { Excluding } \\
\text { duplicate } \\
\text { observations } \\
\text { (2) }\end{array}$ & $\begin{array}{l}\text { Excluding } \\
\text { applicants } \\
\text { from private } \\
\text { schools } \\
\text { (3) }\end{array}$ & $\begin{array}{c}\text { Excluding } \\
\text { students who } \\
\text { did not rank an } \\
\text { exam school } \\
\text { (4) }\end{array}$ & $\begin{array}{c}\text { Excluding } \\
\text { students who } \\
\text { are not ranked } \\
\text { by an exam } \\
\text { school } \\
(5)\end{array}$ & $\begin{array}{c}\text { Excluding } \\
\text { students who } \\
\text { obtain an offer } \\
\text { at a school } \\
\text { they do not } \\
\text { rank } \\
(6)\end{array}$ & $\begin{array}{c}\text { Excluding } \\
\text { students not } \\
\text { matched to } \\
\text { Boston Public } \\
\text { Schools at } \\
\text { baseline } \\
(7)\end{array}$ & $\begin{array}{l}\text { Excluding } \\
\text { students } \\
\text { previously } \\
\text { enrolled in } \\
\text { exam school } \\
\text { (8) }\end{array}$ & $\begin{array}{c}\text { Excluding } \\
\text { students with } \\
\text { no observed } \\
\text { outcome } \\
\text { MCAS test } \\
\text { scores } \\
(9) \\
\end{array}$ \\
\hline & \multicolumn{9}{|c|}{ A. 7th Grade Applicants } \\
\hline 1999 & 2353 & 2353 & 1353 & 1307 & 1307 & 1307 & 1180 & 1180 & 1000 \\
\hline 2000 & 2283 & 2283 & 1252 & 1165 & 1165 & 1165 & 1125 & 1125 & 1032 \\
\hline 2001 & 2317 & 2317 & 1299 & 1196 & 1196 & 1196 & 1193 & 1193 & 1100 \\
\hline 2002 & 2365 & 2365 & 1304 & 1237 & 1236 & 1236 & 1235 & 1235 & 1118 \\
\hline 2003 & 2494 & 2494 & 1386 & 1251 & 1251 & 1251 & 1240 & 1240 & 1127 \\
\hline 2004 & 2217 & 2217 & 1206 & 1174 & 1174 & 1174 & 1172 & 1172 & 1083 \\
\hline 2005 & 2062 & 2062 & 1116 & 1105 & 1105 & 1099 & 1095 & 1095 & 1001 \\
\hline 2006 & 2079 & 2079 & 1184 & 1166 & 1166 & 1161 & 1158 & 1158 & 1052 \\
\hline 2007 & 1992 & 1992 & 1086 & 1081 & 1080 & 1073 & 1068 & 1068 & 974 \\
\hline 2008 & 1874 & 1874 & 1050 & 1049 & 1040 & 1036 & 998 & 998 & 898 \\
\hline \multirow[t]{2}{*}{ All Years } & 22036 & 22036 & 12236 & 11731 & 11720 & 11698 & 11464 & 11464 & 10385 \\
\hline & \multicolumn{9}{|c|}{ B. 9th Grade Applicants } \\
\hline 2001 & 1520 & 1520 & 863 & 787 & 787 & 787 & 783 & 680 & 496 \\
\hline 2002 & 1607 & 1607 & 876 & 829 & 828 & 828 & 826 & 755 & 553 \\
\hline 2003 & 1750 & 1750 & 951 & 812 & 812 & 812 & 809 & 727 & 546 \\
\hline 2004 & 1723 & 1723 & 936 & 918 & 918 & 918 & 912 & 815 & 631 \\
\hline 2005 & 1630 & 1630 & 936 & 924 & 924 & 924 & 918 & 832 & 642 \\
\hline 2006 & 1729 & 1729 & 992 & 981 & 981 & 981 & 977 & 889 & 677 \\
\hline 2007 & 1684 & 1683 & 945 & 936 & 931 & 931 & 930 & 842 & 612 \\
\hline All Years & 11643 & 11642 & 6499 & 6187 & 6181 & 6181 & 6155 & 5540 & 4157 \\
\hline
\end{tabular}

Notes: This table summarizes the steps going from the raw application data to the analysis sample. 
Table C2. Data Structure and Test Outcomes for Boston

\begin{tabular}{|c|c|c|c|c|c|c|c|c|c|}
\hline $\begin{array}{c}\text { Application } \\
\text { Year }\end{array}$ & $\begin{array}{c}\text { Math } 7 \\
\text { (1) }\end{array}$ & $\begin{array}{c}\text { Math } 8 \\
\text { (2) }\end{array}$ & $\begin{array}{l}\text { Math } 10 \\
\text { (3) }\end{array}$ & $\begin{array}{c}\text { English } 7 \\
\text { (4) }\end{array}$ & $\begin{array}{c}\text { English } 8 \\
(5)\end{array}$ & $\begin{array}{c}\text { English } 10 \\
(6)\end{array}$ & $\begin{array}{l}\text { PSAT } \\
(7)\end{array}$ & $\begin{array}{l}\text { SAT } \\
(8)\end{array}$ & $\begin{array}{l}\text { AP } \\
(9)\end{array}$ \\
\hline \multicolumn{10}{|c|}{ A. 7th Grade Applicants } \\
\hline 1999 & & 2001 & 2003 & & & 2003 & & & 2005 \\
\hline 2000 & & 2002 & 2004 & 2001 & & 2004 & 2004 & 2006 & 2006 \\
\hline 2001 & & 2003 & 2005 & 2002 & & 2005 & 2005 & 2007 & 2007 \\
\hline 2002 & & 2004 & 2006 & 2003 & & 2006 & 2006 & 2008 & 2008 \\
\hline 2003 & & 2005 & 2007 & 2004 & & 2007 & 2007 & 2009 & 2009 \\
\hline 2004 & & 2006 & 2008 & 2005 & 2006 & 2008 & 2008 & 2010 & 2010 \\
\hline 2005 & 2006 & 2007 & 2009 & 2006 & 2007 & 2009 & 2009 & & \\
\hline 2006 & 2007 & 2008 & & 2007 & 2008 & & & & \\
\hline 2007 & 2008 & 2009 & & 2008 & 2009 & & & & \\
\hline 2008 & 2009 & & & 2009 & & & & & \\
\hline \multicolumn{10}{|c|}{ B. 9th Grade Applicants } \\
\hline 2001 & & & 2003 & & & 2003 & & 2005 & 2005 \\
\hline 2002 & & & 2004 & & & 2004 & 2004 & 2006 & 2006 \\
\hline 2003 & & & 2005 & & & 2005 & 2005 & 2007 & 2007 \\
\hline 2004 & & & 2006 & & & 2006 & 2006 & 2008 & 2008 \\
\hline 2005 & & & 2007 & & & 2007 & 2007 & 2009 & 2009 \\
\hline 2006 & & & 2008 & & & 2008 & 2008 & 2010 & 2010 \\
\hline 2007 & & & 2009 & & & 2009 & 2009 & & \\
\hline
\end{tabular}

Notes: This table reports the applicant cohorts and test year outcomes. Application year refers to the fall of application year, while test outcome year refers to the spring of year. Test outcomes are available based on the schedule of the MCAS and availability of SAT, PSAT and AP score outcomes. 
Table C3. Match from Boston Exam Application to Enrollment Data

\begin{tabular}{ccccc}
\hline & Number of & \multicolumn{3}{c}{ Fraction with Match } \\
\cline { 3 - 5 } Application & Students & Total & Offered & Not Offered \\
Year & $(1)$ & $(2)$ & $(3)$ & $(4)$ \\
\hline & & A. 7 th Grade Applicants & \\
1999 & 1307 & 0.903 & 0.919 & 0.890 \\
2000 & 1165 & 0.966 & 0.958 & 0.972 \\
2001 & 1196 & 0.997 & 0.996 & 0.998 \\
2002 & 1236 & 0.999 & 1.000 & 0.999 \\
2003 & 1251 & 0.991 & 0.996 & 0.987 \\
2004 & 1174 & 0.998 & 1.000 & 0.997 \\
2005 & 1099 & 0.996 & 0.996 & 0.996 \\
2006 & 1161 & 0.997 & 0.995 & 1.000 \\
2007 & 1073 & 0.995 & 1.000 & 0.991 \\
2008 & 1036 & 0.963 & 0.980 & 0.946 \\
All Years & 14212 & 0.966 & 0.969 & 0.963 \\
& & & & \\
2001 & & B.9th Grade Applicants & \\
2002 & 787 & 0.995 & 1.000 & 0.993 \\
2003 & 828 & 0.998 & 1.000 & 0.997 \\
2004 & 812 & 0.996 & 1.000 & 0.995 \\
2005 & 918 & 0.993 & 1.000 & 0.992 \\
2006 & 924 & 0.994 & 0.992 & 0.994 \\
2007 & 981 & 0.996 & 1.000 & 0.994 \\
All Years & 931 & 0.999 & 1.000 & 0.999 \\
\hline & 6181 & 0.996 & 0.999 & 0.995 \\
\hline
\end{tabular}

Notes: This table provides summary statistics on the match between the exam school application data and the Boston Public School enrollment file. The sample in column (1) is the sample in column (6) of Table $\mathrm{C} 1$. 
Table C4. Test Outcome Data for Boston Exam School Applicants

\begin{tabular}{|c|c|c|c|c|c|c|}
\hline Application Year & $\begin{array}{l}\text { Number of } \\
\text { students } \\
\text { (1) }\end{array}$ & $\begin{array}{l}\text { Number with an } \\
\text { observed test } \\
\text { score } \\
\text { (2) }\end{array}$ & $\begin{array}{c}\text { Number of Math } \\
\text { test scores } \\
\text { expected } \\
\text { (3) }\end{array}$ & $\begin{array}{l}\text { Math test scores } \\
\text { observed } \\
\text { (4) }\end{array}$ & $\begin{array}{c}\text { Number of } \\
\text { English test scores } \\
\text { expected } \\
\text { (5) }\end{array}$ & $\begin{array}{c}\text { English test scores } \\
\text { observed } \\
(6)\end{array}$ \\
\hline & \multicolumn{6}{|c|}{ 7th Grade } \\
\hline 1999 & 1180 & 1000 & 2360 & 1765 & 1180 & 800 \\
\hline 2000 & 1125 & 1032 & 2250 & 1776 & 2250 & 1792 \\
\hline 2001 & 1193 & 1100 & 2386 & 1843 & 2386 & 1897 \\
\hline 2002 & 1235 & 1118 & 2470 & 1894 & 2470 & 1945 \\
\hline 2003 & 1240 & 1127 & 2480 & 1897 & 2480 & 2006 \\
\hline 2004 & 1172 & 1083 & 2344 & 1842 & 3516 & 2890 \\
\hline 2005 & 1095 & 1001 & 3285 & 2650 & 3285 & 2650 \\
\hline 2006 & 1158 & 1052 & 2316 & 2039 & 2316 & 2038 \\
\hline 2007 & 1068 & 974 & 2136 & 1884 & 2136 & 1879 \\
\hline 2008 & 998 & 898 & 998 & 895 & 998 & 897 \\
\hline \multirow[t]{2}{*}{ All Years } & 11464 & 10385 & 23025 & 18485 & 23017 & 18794 \\
\hline & \multicolumn{6}{|c|}{ 9th Grade } \\
\hline 2001 & 680 & 496 & 680 & 496 & 680 & 495 \\
\hline 2002 & 755 & 553 & 755 & 551 & 755 & 550 \\
\hline 2003 & 727 & 546 & 727 & 545 & 727 & 543 \\
\hline 2004 & 815 & 631 & 815 & 621 & 815 & 630 \\
\hline 2005 & 832 & 642 & 832 & 630 & 832 & 636 \\
\hline 2006 & 889 & 677 & 889 & 662 & 889 & 673 \\
\hline 2007 & 842 & 612 & 842 & 603 & 842 & 610 \\
\hline All Years & 5540 & 4157 & 5540 & 4108 & 5540 & 4137 \\
\hline
\end{tabular}

Notes: This table summarizes the observed test score outcomes for exam school applicants. The sample is restricted to students in column (8) of Table C1. 
Table C5. Matching of College Board Test Outcome Data for Boston Applicants

\begin{tabular}{|c|c|c|c|c|c|c|c|c|c|}
\hline $\begin{array}{c}\text { Application } \\
\text { Year }\end{array}$ & $\begin{array}{l}\text { Number of } \\
\text { applicants } \\
\text { (1) }\end{array}$ & $\begin{array}{c}\text { Number with an } \\
\text { observed PSAT } \\
\text { test score } \\
\text { (2) }\end{array}$ & $\begin{array}{l}\text { Number with an } \\
\text { expected PSAT } \\
\text { test score } \\
\text { (enrolled as of } \\
\text { grade 11) } \\
\text { (3) }\end{array}$ & $\begin{array}{l}\text { Number with an } \\
\text { observed SAT } \\
\text { test score } \\
\text { (4) }\end{array}$ & $\begin{array}{l}\text { Number with an } \\
\text { expected SAT } \\
\text { test score } \\
\text { (enrolled as of } \\
\text { grade 11) } \\
(5)\end{array}$ & $\begin{array}{l}\text { Number with an } \\
\text { observed AP test } \\
\text { score } \\
(6)\end{array}$ & $\begin{array}{c}\text { Number with an } \\
\text { expected AP test } \\
\text { score (enrolled } \\
\text { as of grade 12) } \\
(7)\end{array}$ & $\begin{array}{l}\text { Number with } \\
\text { observed NSC } \\
\text { outcomes } \\
\text { (8) }\end{array}$ & $\begin{array}{l}\text { Number with } \\
\text { expected NSC } \\
\text { outcomes } \\
\text { (enrolled as of } \\
\text { grade 12) } \\
(9)\end{array}$ \\
\hline & & & & & A. 7th Grade & & & & \\
\hline 1999 & 1,180 & 50 & 0 & 640 & 0 & 291 & 1,180 & 840 & 1,180 \\
\hline 2000 & 1,125 & 707 & 1,125 & 647 & 1,125 & 341 & 1,125 & 879 & 1,125 \\
\hline 2001 & 1,193 & 826 & 1,193 & 710 & 1,193 & 432 & 1,193 & 959 & 1,193 \\
\hline 2002 & 1,235 & 834 & 1,235 & 683 & 1,235 & 427 & 1,235 & 1053 & 1,235 \\
\hline 2003 & 1,240 & 844 & 1,240 & 687 & 1,240 & 481 & 1,240 & 1059 & 1,240 \\
\hline 2004 & 1,172 & 788 & 1,172 & 679 & 1,172 & 499 & 1,172 & 949 & 1,172 \\
\hline 2005 & 1,095 & 664 & 1,095 & 3 & 0 & 345 & 0 & 202 & 0 \\
\hline 2006 & 1,158 & 10 & 0 & 0 & 0 & 14 & 0 & 137 & 0 \\
\hline 2007 & 1,068 & 0 & 0 & 0 & 0 & 0 & 0 & 115 & 0 \\
\hline 2008 & 998 & 0 & 0 & 0 & 0 & 0 & 0 & 0 & 0 \\
\hline \multirow[t]{2}{*}{ All Years } & 11,464 & 4,723 & 7,060 & 4,049 & 5,965 & 2,830 & 7,145 & 6,193 & 7,145 \\
\hline & & & & & B. 9th Grade & & & & \\
\hline 2001 & 680 & 22 & 0 & 374 & 680 & 113 & 680 & 522 & 680 \\
\hline 2002 & 755 & 462 & 755 & 413 & 755 & 159 & 755 & 602 & 755 \\
\hline 2003 & 727 & 520 & 727 & 426 & 727 & 177 & 727 & 618 & 727 \\
\hline 2004 & 815 & 635 & 815 & 478 & 815 & 235 & 815 & 786 & 815 \\
\hline 2005 & 832 & 598 & 832 & 454 & 832 & 255 & 832 & 805 & 832 \\
\hline 2006 & 889 & 612 & 889 & 481 & 889 & 290 & 889 & 797 & 889 \\
\hline 2007 & 842 & 528 & 842 & 2 & 0 & 142 & 0 & 201 & 0 \\
\hline All Years & 5,540 & 3,377 & 4,860 & 2,628 & 4,698 & 1,371 & 4,698 & 4,331 & 4,698 \\
\hline
\end{tabular}

Notes: This table summarizes the observed College Board test score outcomes for exam school applicants. The sample is restricted to students in column (8) of Table C1. 
Table D1. Processing of NYC Exam School Application Data

\begin{tabular}{|c|c|c|c|c|}
\hline \multirow[t]{2}{*}{ Application Year } & Total number of records & $\begin{array}{l}\text { Excluding applicants from } \\
\text { private schools }\end{array}$ & $\begin{array}{l}\text { Excluding applicants not } \\
\text { in Round } 1 \text { of the } \\
\text { application process }\end{array}$ & $\begin{array}{c}\text { Excluding students who } \\
\text { did not rank an exam } \\
\text { school }\end{array}$ \\
\hline & $(1)$ & $(2)$ & $(3)$ & $(4)$ \\
\hline 2003-04 & 28,136 & 23,637 & 22,293 & 22,287 \\
\hline 2004-05 & 28,279 & 24,123 & 22,894 & 22,859 \\
\hline $2005-06$ & 28,442 & 23,971 & 22,810 & 22,810 \\
\hline 2006-07 & 26,616 & 22,377 & 21,278 & 21,278 \\
\hline All Years & 111,473 & 94,108 & 89,275 & 89,234 \\
\hline \multirow[t]{2}{*}{ Application Year } & $\begin{array}{l}\text { Excluding students not } \\
\text { matched to student file }\end{array}$ & Excluding 9th graders & $\begin{array}{c}\text { Excluding students who } \\
\text { took SHSAT in previous } \\
\text { years }\end{array}$ & $\begin{array}{l}\text { Excluding students without } \\
\text { post-assignment numeric } \\
\text { outcome test scores at all }\end{array}$ \\
\hline & $(6)$ & $(7)$ & $(8)$ & $(9)$ \\
\hline 2003-04 & 22,108 & 21,091 & 21,091 & 18,361 \\
\hline 2004-05 & 22,776 & 21,883 & 21,880 & 19,106 \\
\hline 2005-06 & 22,376 & 21,448 & 21,446 & 18,842 \\
\hline $2006-07$ & 20,824 & 20,124 & 20,122 & 17,431 \\
\hline All Years & 88,084 & 84,546 & 84,539 & 73,740 \\
\hline
\end{tabular}

Notes: This table summarizes the steps going from raw application data to the analysis sample.

Excluding students who did not rank Brooklyn Tech, Bronx Science or Stuyvesant
(5)

22,205

22,776

22,376

20,824

88,181 
Table D2. Match from NYC Exam Application to Student Data

\begin{tabular}{ccccc}
\hline & Number of & \multicolumn{3}{c}{ Fraction with Match } \\
\cline { 3 - 5 } Application Year & Students & Total & Offered & Not Offered \\
& $(1)$ & $(2)$ & $(3)$ & $(4)$ \\
\hline $2003-04$ & 22,205 & 0.996 & 0.997 & 0.995 \\
$2004-05$ & 22,776 & 1 & 1 & 1 \\
$2005-06$ & 22,376 & 1 & 1 & 1 \\
$2006-07$ & 20,824 & 1 & 1 & 1 \\
All Years & 88,181 & 0.999 & 0.999 & 0.999 \\
\hline
\end{tabular}

Notes: This table reports the fraction of applicants with a match between the exam application file and the student demographic file. The sample corresponds to column (5) of Table D1. 
Table D3. Match from NYC Exam Applicants to Regents Test Score Outcomes

\begin{tabular}{|c|c|c|c|c|c|}
\hline \multirow[b]{2}{*}{ Record Availability } & \multicolumn{5}{|c|}{ Application School Year } \\
\hline & $\begin{array}{c}2003-04 \\
\text { (1) }\end{array}$ & $\begin{array}{c}2004-05 \\
(2)\end{array}$ & $\begin{array}{c}\text { 2005-06 } \\
\text { (3) }\end{array}$ & $\begin{array}{c}2006-07 \\
(4)\end{array}$ & $\begin{array}{c}\text { All Years } \\
\text { (5) }\end{array}$ \\
\hline & \multicolumn{5}{|c|}{ I. Math } \\
\hline Number of applicants & 21,091 & 21,880 & 21,446 & 20,122 & 84,539 \\
\hline Number with score observed before treatment & 2,685 & 3,157 & 3,673 & 3,975 & 13,490 \\
\hline Number with score observed after treatment & 15,055 & 15,307 & 14,206 & 12,492 & 57,060 \\
\hline Number with different multiple scores observed after treatment & 1,795 & 2,360 & 2,000 & 1,821 & 7,976 \\
\hline Number with different multiple scores observed after treatment, on first date & 3 & 20 & 10 & 2 & 35 \\
\hline Number with score observed on most common date & 5,822 & 5,873 & 6,078 & 8,033 & 25,806 \\
\hline Number with score observed before most common date & 3,522 & 3,875 & 4,348 & 2,022 & 13,767 \\
\hline \multirow[t]{2}{*}{ Number with score observed after most common date } & 5,711 & 5,559 & 3,779 & 2,437 & 17,486 \\
\hline & \multicolumn{4}{|c|}{ II. Advanced Math } & \\
\hline Number of applicants & 21,091 & 21,880 & 21,446 & 20,122 & 84,539 \\
\hline Number with score observed before treatment & 7 & 9 & 13 & 29 & 58 \\
\hline Number with score observed after treatment & 10,375 & 10,691 & 10,939 & 12,130 & 44,135 \\
\hline Number with different multiple scores observed after treatment & 1,469 & 1,750 & 898 & 235 & 4,352 \\
\hline Number with different multiple scores observed after treatment, on first date & 13 & 4 & 0 & 0 & 17 \\
\hline Number with score observed on most common date & 3,913 & 3,938 & 5,496 & 11,177 & 24,524 \\
\hline Number with score observed before most common date & 4,310 & 4,671 & 5,443 & 953 & 15,377 \\
\hline \multirow[t]{2}{*}{ Number with score observed after most common date } & 2,152 & 2,082 & 0 & 0 & 4,234 \\
\hline & \multicolumn{4}{|c|}{ III. English } & \\
\hline Number of applicants & 21,091 & 21,880 & 21,446 & 20,122 & 84,539 \\
\hline Number with score observed before treatment & 2 & 1 & 0 & n.a & 14 \\
\hline Number with score observed after treatment & 16,847 & 17,322 & 17,202 & n.a & 54,410 \\
\hline Number with different multiple scores observed after treatment & 1,979 & 2,024 & 1,501 & n.a & 5,641 \\
\hline Number with different multiple scores observed after treatment, on first date & 11 & 3 & 0 & n.a & 14 \\
\hline Number with score observed on most common date & 9,333 & 8,614 & 8,985 & n.a & 29,389 \\
\hline Number with score observed before most common date & 1,829 & 2,587 & 2,705 & n.a & 7,703 \\
\hline \multirow[t]{2}{*}{ Number with score observed after most common date } & 5,685 & 6,120 & 5,512 & n.a & 17,317 \\
\hline & \multicolumn{4}{|c|}{ IV. Global History } & \\
\hline Number of applicants & 21,091 & 21,880 & 21,446 & 20,122 & 84,539 \\
\hline Number with score observed before treatment & 3 & 19 & 18 & 8 & 48 \\
\hline Number with score observed after treatment & 17,057 & 17,735 & 16,434 & 15,429 & 66,655 \\
\hline Number with different multiple scores observed after treatment & 2,321 & 2,882 & 1,771 & 203 & 7,177 \\
\hline Number with different multiple scores observed after treatment, on first date & 19 & 59 & 1 & 0 & 79 \\
\hline Number with score observed on most common date & 13,746 & 13,471 & 13,100 & 14,328 & 54,645 \\
\hline Number with score observed before most common date & 796 & 844 & 1,037 & 1,101 & 3,778 \\
\hline \multirow[t]{2}{*}{ Number with score observed after most common date } & 2,514 & 3,420 & 2,296 & 0 & 8,230 \\
\hline & \multicolumn{4}{|c|}{ V. US History } & \\
\hline Number of applicants & 21,091 & 21,880 & 21,446 & 20,122 & 84,539 \\
\hline Number with score observed before treatment & 41 & 23 & 91 & n.a & 256 \\
\hline Number with score observed after treatment & 15,766 & 16,015 & 14,270 & n.a & 47,906 \\
\hline Number with different multiple scores observed after treatment & 1,152 & 1,102 & 496 & n.a & 2,962 \\
\hline Number with different multiple scores observed after treatment, on first date & 20 & 0 & 3 & n.a & 23 \\
\hline Number with score observed on most common date & 10,252 & 10,365 & 11,844 & n.a & 33,431 \\
\hline Number with score observed before most common date & 1,464 & 2,068 & 2,426 & n.a & 6,013 \\
\hline \multirow[t]{2}{*}{ Number with score observed after most common date } & 4,049 & 3,582 & 0 & n.a & 8,461 \\
\hline & \multicolumn{4}{|c|}{ VI. Living Environment } & \\
\hline Number of applicants & 21,091 & 21,880 & 21,446 & 20,122 & 84,539 \\
\hline Number with score observed before treatment & 440 & 878 & 894 & 922 & 3,134 \\
\hline Number with score observed after treatment & 16,562 & 16,807 & 16,310 & 14,102 & 63,781 \\
\hline Number with different multiple scores observed after treatment & 1,356 & 1,807 & 1,484 & 977 & 5,624 \\
\hline Number with different multiple scores observed after treatment, on first date & 2 & 7 & 8 & 0 & 17 \\
\hline Number with score observed on most common date & 11,601 & 11,455 & 11,286 & 11,071 & 45,413 \\
\hline Number with score observed before most common date & 207 & 324 & 344 & 209 & 1,084 \\
\hline Number with score observed after most common date & 4,754 & 5,027 & 4,679 & 2,822 & 17,282 \\
\hline
\end{tabular}

Notes: This table summarizes the match between Regents test score outcomes and exam school applicants. The sample is restricted to students in column (8) of Table D1. 